\title{
Carbon-Based Materials for Oxidative Desulfurization and Denitrogenation of Fuels: A Review
}

\author{
Fernanda F. Roman ${ }^{1,2,3}{ }^{1}$, Jose L. Diaz de Tuesta ${ }^{1}\left(\mathbb{D}\right.$, Adrián M. T. Silva ${ }^{2,3} \mathbb{C}^{\text {, Joaquim L. Faria }}{ }^{2,3}$ \\ and Helder T. Gomes $1, *$ (iD) \\ 1 Centro de Investigação de Montanha (CIMO), Instituto Politécnico de Bragança, \\ 5300-253 Bragança, Portugal; roman@ipb.pt (F.F.R.); jl.diazdetuesta@ipb.pt (J.L.D.d.T.) \\ 2 Laboratory of Separation and Reaction Engineering-Laboratory of Catalysis and Materials (LSRE-LCM), \\ Faculdade de Engenharia, Universidade do Porto, 4200-465 Porto, Portugal; adrian@fe.up.pt (A.M.T.S.); \\ jlfaria@fe.up.pt (J.L.F.) \\ 3 ALiCE-Associate Laboratory in Chemical Engineering, Faculdade de Engenharia, Universidade do Porto, \\ 4200-465 Porto, Portugal \\ * Correspondence: htgomes@ipb.pt
}

check for updates

Citation: Roman, F.F.; Diaz de Tuesta, J.L.; Silva, A.M.T.; Faria, J.L.; Gomes, H.T. Carbon-Based Materials for Oxidative Desulfurization and Denitrogenation of Fuels: A Review. Catalysts 2021, 11, 1239. https:// doi.org/10.3390/catal11101239

Academic Editor: Lucian Baia

Received: 24 September 2021

Accepted: 12 October 2021

Published: 15 October 2021

Publisher's Note: MDPI stays neutral with regard to jurisdictional claims in published maps and institutional affiliations.

Copyright: (c) 2021 by the authors. Licensee MDPI, Basel, Switzerland. This article is an open access article distributed under the terms and conditions of the Creative Commons Attribution (CC BY) license (https:// creativecommons.org/licenses/by/ $4.0 /)$.

\begin{abstract}
Sulfur (S) and nitrogen (N) are elements naturally found in petroleum-based fuels. Sand N-based compounds in liquid fuels are associated with a series of health and environmental issues. Thus, legislation has become stricter worldwide regarding their content and related emissions. Traditional treatment systems (namely hydrodesulfurization and hydrodenitrogenation) fail to achieve the desired levels of $\mathrm{S}$ and $\mathrm{N}$ contents in fuels without compromising combustion parameters. Thus, oxidative treatments (oxidative desulfurization-ODS, and oxidative denitrogenation-ODN) are emerging as alternatives to producing ultra-low-sulfur and nitrogen fuels. This paper presents a thorough review of ODS and ODN processes applying carbon-based materials, either in hybrid forms or as catalysts on their own. Focus is brought to the role of the carbonaceous structure in oxidative treatments. Furthermore, a special section related to the use of amphiphilic carbon-based catalysts, which have some advantages related to a closer interaction with the oily and aqueous phases, is discussed.
\end{abstract}

Keywords: desulfurization; denitrogenation; carbon catalysts; carbon composites; biphasic oxidation; amphiphilic material; low-sulfur fuels; liquid fuels

\section{Introduction}

With increasing urbanization, humankind has experienced an escalating dependence on energy. As shown in Figure 1, for EU-28, total energy supply amounted to 1.58M toe (tonnes of oil equivalent) in 2019, and oil and petroleum products represented the highest contribution $(32.8 \%)$, followed by natural gas $(25 \%)$, renewables and biofuels $(15.8 \%)$, nuclear heat $(13.2 \%)$, and solid fossil fuels (11\%). In particular, the contribution of oil and petroleum products in energy supplies has kept with no relevant changes (31.4-33.0\%) in the last decade (Figure 1a), with values ranging from 510k (2014) to 569k (2010) toe. Oil and petroleum products are extensively used in our society for transportation, electricity, and construction materials. Transportation may be the sector that most relies on petroleum-based fuels, from ground transportation to planes and ships. In EU-28, the final consumption of energy in the transport sector amounted to $330.8 \mathrm{k}$ toe in 2019, being $209.8 \mathrm{k}$ toe of gas oil and diesel, $79.1 \mathrm{k}$ toe of motor gasoline, $17.4 \mathrm{k}$ toe of renewables and biodiesel, and 3.7k toe of natural gas (Figure 1b). In the last decade, gasoline consumption has decreased from $28.5 \%$ to $23.9 \%$ of the total energy consumed in the transportation sector, whereas gas oil and diesel have increased from $60.7 \%$ to $63.4 \%$ (Figure $1 \mathrm{~b}$ ). 

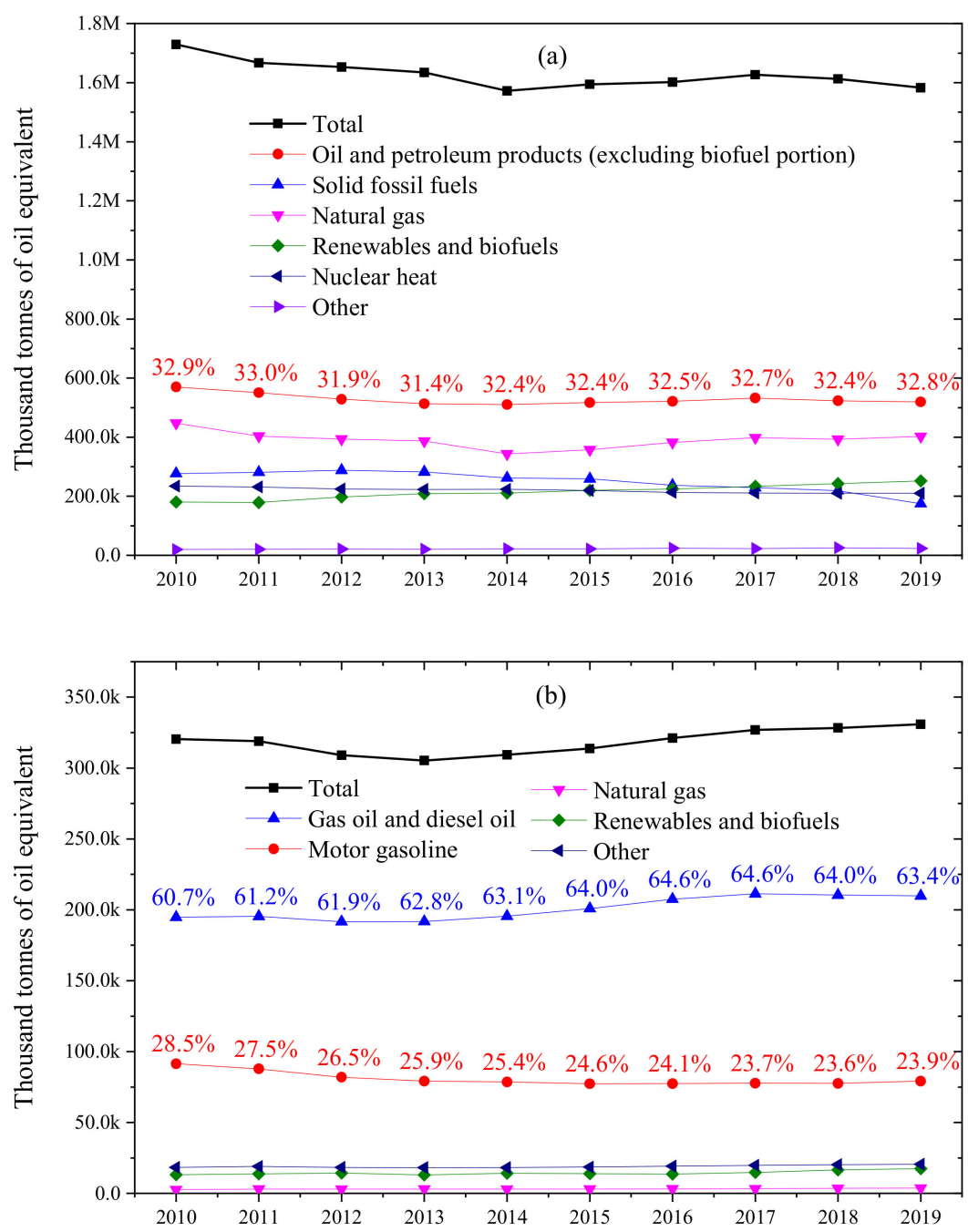

Figure 1. Evolution of (a) total energy supply and (b) final consumption in the transport sector (only energy use) in EU 28. Source: Eurostat [1].

Some heteroatoms are inherently found in petroleum and petroleum-based fuels. The atom found in the highest concentration after carbon and hydrogen is sulfur, followed by nitrogen. Their presence is associated with a series of environmental and health-related issues due to the formation of toxic gaseous products $\left(\mathrm{NO}_{\mathrm{x}}\right.$ and $\left.\mathrm{SO}_{2}\right)$ during combustion. Those issues have driven legislative bodies to regulate the content and related emissions of S- and N-based compounds, increasing restrictions. Hydrodesulfurization (HDS) and hydrodenitrogenation $(\mathrm{HDN})$ are the technologies applied at the industrial level. However, HDS and HDN fail to achieve the required-by-law content of sulfur without compromising relevant combustion parameters of the fuels (such as diesel and gasoline). Alternative technologies have been studied in the last few years and, among them, oxidative treatments can be highlighted, namely oxidative desulfurization (ODS) and denitrogenation (ODN). As with any catalytic process, the development and selection of catalysts are critical in ODS and ODN, and carbon-based materials have revealed exciting results in the oxidative removal of S- and N-based compounds. This review aims to discuss the state-of-the-art application of carbon-based materials for ODS and ODN purposes, emphasizing the role displayed by those materials, either in hybrid forms or as carbocatalysts. 


\subsection{Sulfur and Nitrogen in Crude Oils: Content and Type of Compounds}

Petroleum is composed mostly of hydrocarbons, although impurities such as nitrogen, sulfur, oxygen, and metal compounds (vanadium, nickel, and iron, among others) are found [2]. Sulfur is the component that varies the most between different petroleum samples [2] and is the third most abundant element in crude oils, after carbon and hydrogen [3]. Sulfur content can vary between $<0.1$ to $8 \mathrm{wt}$.\% [2], leading to the classifications of sweet crude oils ( $\mathrm{S}$ content $<1 \mathrm{wt} . \%$ ) or sour oils (S content $>1 \mathrm{wt} . \%$ ) [3]. Nitrogen content can vary between $<0.1$ to $1.8 \mathrm{wt} . \%$ [2], and crudes can be classified as high-nitrogen oils ( $>0.25 \mathrm{wt} . \%)$ or nitrogen-poor oils ( $<0.25 \mathrm{wt} . \%)$ [4]. Table 1 displays some examples of the content of sulfur and nitrogen in different crude oil samples. There is no correlation between the content of sulfur and nitrogen. The content of those impurities depends mostly on the area of exploration $[4,5]$.

Table 1. Sulfur and nitrogen content for crude oil in different regions.

\begin{tabular}{cccc}
\hline Local of Exploration & Type of Oil & $\begin{array}{c}\text { S Content } \\
\text { (wt. \%) }\end{array}$ & $\begin{array}{c}\text { N Content } \\
\text { (wt. \%) }\end{array}$ \\
\hline USA, AR, Atlanta & Petroleum (Light oil) & 0.37 & 0.003 \\
USA, CA, Temblor & Petroleum (Medium oil) & 0.44 & 0.27 \\
USA, CA, Oxnard & Petroleum (Heavy oil) & 7.47 & 0.88 \\
USA, MS, Eucutta & Petroleum (Heavy oil) & 3.89 & 0.13 \\
Iran, Agha-Jeri & Petroleum (Light oil) & 1.36 & 0.14 \\
Greece, Keri & Petroleum (Heavy oil) & 5.76 & 0.17 \\
Australia, Pumpherston & Shale oil (Medium oil) & 0.56 & 0.52 \\
France, Petit & Shale oil (Medium oil) & 3.40 & 0.65 \\
South Africa, Salermo & Shale oil (Medium oil) & 0.64 & 0.85 \\
Sweden, Lundstrom & Shale oil (Light oil) & 0.71 & 0.11 \\
\hline Source: adapted from Ball, Whisman, and Wenger (1951) [6]. & &
\end{tabular}

Source: adapted from Ball, Whisman, and Wenger (1951) [6].

S-containing compounds found in petroleum can be divided into four main groups: mercaptans (R-SH), sulfides $\left(\mathrm{R}_{2} \mathrm{~S}\right)$, disulfides (RSSR), and thiophenes. Some examples of these compounds can be seen in Figure 2. Other compounds may include $\mathrm{H}_{2} \mathrm{~S}$ and elemental sulfur, although in trace quantities [7]. $\mathrm{N}$-containing compounds are classified into two major groups: basic (derived from pyridine) and non-basic or neutral (derived from pyrrole) [4]. Figure 3 displays some $\mathrm{N}$-containing compounds commonly found in petroleum. There is also evidence of the presence of primary amines $\left(\mathrm{R}-\mathrm{NH}_{2}\right)$, porphyrins structures, or compounds that contain nitrogen and oxygen simultaneously [4].

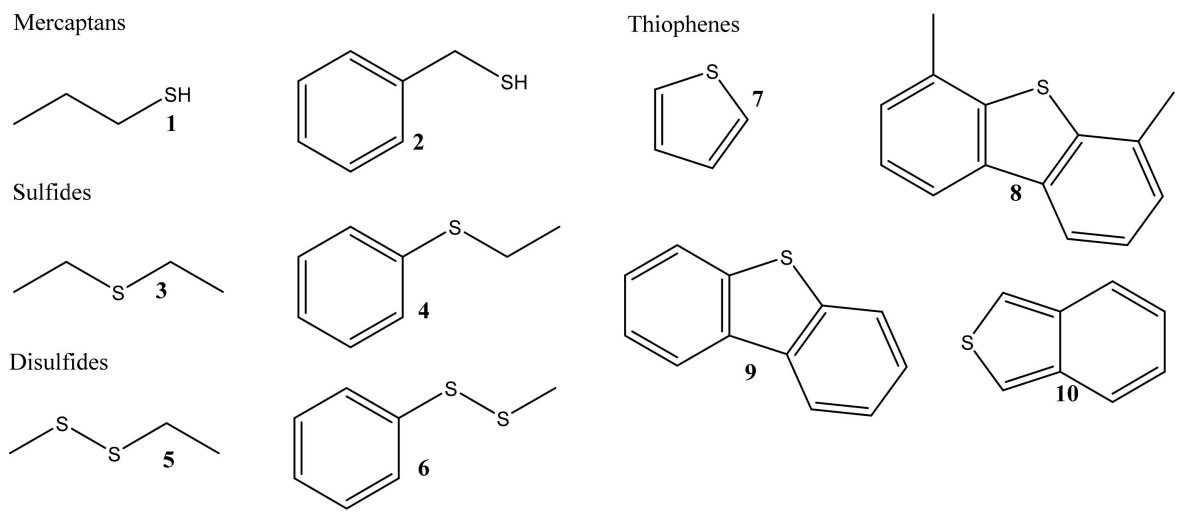

Figure 2. Examples of S-containing compounds found in petroleum. Mercaptans: propane-1thiol 1, phenylmethanethiol 2. Sulfides: diethylsulfane 3, ethyl phenyl sulfide 4. Disulfides: (methyldisulfanyl)methane 5, methyl phenyl disulfide 6. Thiophenes: thiophene (Th) 7, 4,6dimethyldibenzothiophene (4,6-DMDBT) 8, dibenzothiophene (DBT) 9, and benzothiophene (BT) 10. 
Pyridine<smiles>c1ccncc1</smiles><smiles>c1ccc2ncccc2c1</smiles><smiles>c1cc2ccc3cccc4ncc(c1)c2c34</smiles>

Pyrrole<smiles>c1cc[nH]c1</smiles><smiles>c1ccc2[nH]ccc2c1</smiles><smiles>c1ccc2c(c1)[nH]c1ccccc12</smiles>

Figure 3. Examples of N-containing compounds found in petroleum. Pyridines group: pyridine 1, quinoline (QN) 2, azapyrene 3. Pyrroles group: pyrrole 4, indole 5, and carbazole 6.

Heavier boiling fractions contain higher amounts of sulfur compounds (main boiling fractions are displayed in Figure 4). In the gasoline boiling range, mercaptan, sulfide, disulfide, and thiophene groups are found. In contrast, jet fuel and diesel primarily include thiophenes and derivatives [8]. Similarly, the nitrogen content increases for heavier fractions. Most N-compounds occur in the residual boiling fractions [4].

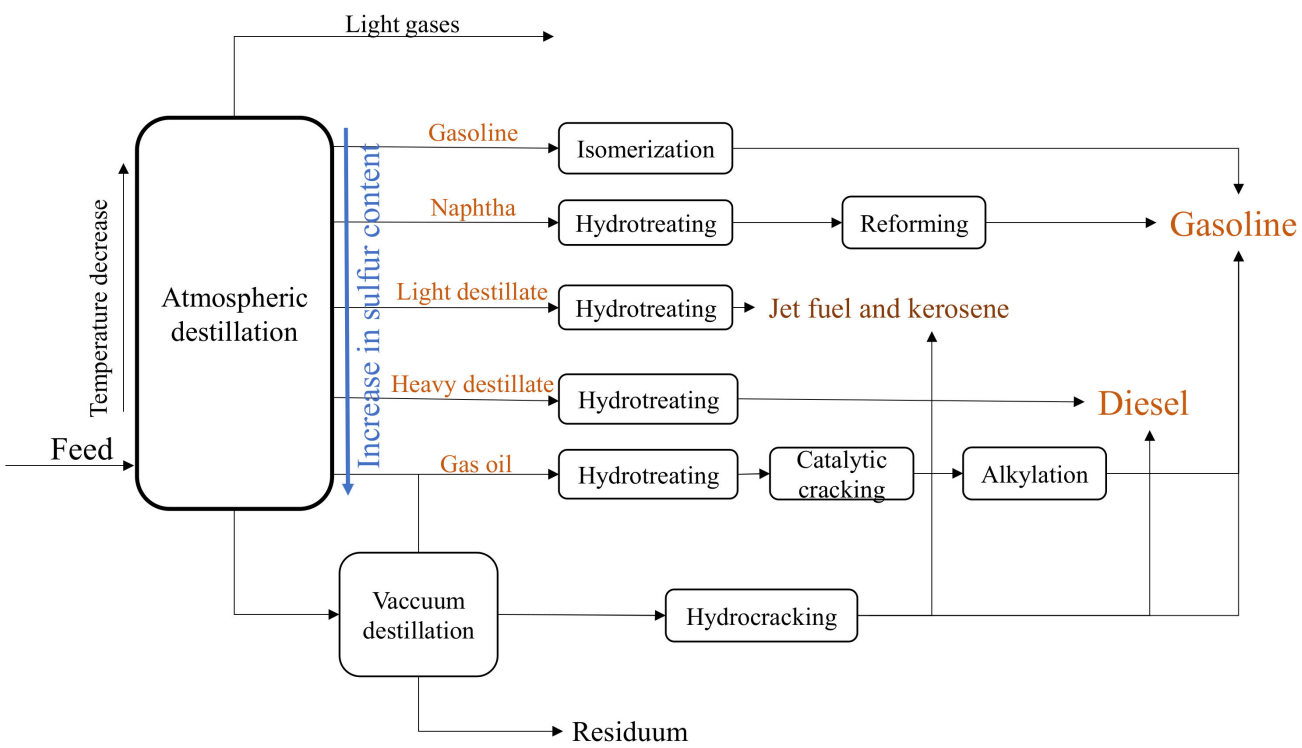

Figure 4. Simplified flowchart of a petroleum refinery and its main boiling fractions. Adapted from Romanow-Garcia and Hoffman (2003) [9].

\subsection{Health, Environmental and Technological Effects of Sulfur-and Nitrogen-Containing Compounds}

Upon combustion of petroleum-based fuels, hazardous gases $\left(\mathrm{SO}_{2}\right.$ and $\left.\mathrm{NO}_{\mathrm{x}}\right)$ and particulate matter (PM) are released [10]. PM can be generated directly during combustion (primary PM) or from the chemical reaction of exhaust gases, including $\mathrm{SO}_{2}$ and $\mathrm{NO}_{\mathrm{x}}$ (secondary PM). The exact composition of the exhaust gas depends on a series of factors, mainly fuel composition and combustion conditions. However, $\mathrm{PM}$ and $\mathrm{NO}_{\mathrm{x}}$ emissions can be controlled by augmenting the cetane number and lowering the number of aromatic compounds in diesel fuels [10], besides reducing the content of N-containing compounds. Reducing the content of sulfur diminishes $\mathrm{SO}_{2}$ and sulfur-based PM [10]. 
Exposure to $\mathrm{SO}_{2}$ and $\mathrm{NO}_{\mathrm{x}}$ is related to several health issues in humans. $\mathrm{NO}_{\mathrm{x}}$ and $\mathrm{SO}_{2}$ are both irritants of the respiratory system and are associated with worsening existing respiratory illnesses, such as asthma, and increased susceptibility to lung infections [11]. Most of the PM emitted in diesel engines ( $>90 \%)$ is smaller than $1 \mu \mathrm{m}$ in diameter [10]. $\mathrm{PM}_{10}$ (aerodynamic diameter $<10 \mu \mathrm{m}$ ) is a nose and throat irritant, causing lung damage, bronchitis, and risk of cardiac arrest, which is even associated with early death [12]. Studies have shown that long-term exposure to diesel combustion products is associated with a $20-50 \%$ increase in the likelihood of developing lung cancer due to genotoxicity $[10,13]$. Similarly, exposition to diesel exhausts is related to a 4-fold increase in the risk of dying of noncancerous diseases, such as cardiovascular diseases [10]. A study done in 2003 found a positive correlation between exposure to an increased daily concentration of $\mathrm{SO}_{2}$ in the atmosphere and hospital admissions for cardiovascular diseases and ischemic heart diseases in major European cities [14]. Mortality and morbidity rates due to $\mathrm{SO}_{2}$ exposure result in relevant monetary costs, as estimated by Wu et al. (2020) (35.76 and 441.47 million RMB Yuan, respectively, for Beijing, China, in 2016) [15].

$\mathrm{NO}_{\mathrm{x}}$ and $\mathrm{SO}_{2}$ also provoke adverse environmental effects. $\mathrm{NO}_{\mathrm{x}}$ and $\mathrm{SO}_{2}$ from exhaust engines combine with air moisture and contribute to acid rain [10]. Acid rain is linked to the depletion of essential soil nutrients, affecting soil fertility [7]. Soil $\mathrm{pH}$ is also altered, destroying some microbial cultures [7]. Soil alterations threaten forest vegetation and crop production. It contributes to dissolving harmful substances (such as heavy metals), leaching to water bodies. It is also associated with lake acidification and water nitrification [16,17], impacting microorganisms' reproduction and growth. Acid rain also affects human-made structures, diminishing the lifespan of buildings, bridges, statues, among others $[7,17]$. Furthermore, both primary and secondary PM reduce atmospheric visibility between 8 and $25 \%$ [10].

Sulfur compounds, mainly $\mathrm{H}_{2} \mathrm{~S}$ and mercaptans, are related to a strong odor in sour petroleum [7]. Furthermore, lower aliphatic sulfides and mercaptans are highly reactive towards metals and cause corrosion, damaging storage tanks, pipelines, and equipment [7]. However, the main issue with S-containing compounds during refining is the deactivation of metal catalysts in downstream units [7]. In hydrogenation, reforming, isomerization, and alkylation processes, sulfur is adsorbed in the catalyst surface. Sulfur adsorption then hinders the adsorption of any other species. The deactivation degree depends on the extension of the active sites that were obstructed. Depending on the metal used as catalyst, irreversible poisoning can happen, and thus the regeneration of the catalyst becomes a difficult task [7]. Additionally, sulfur chemisorbs on the catalysts used in the catalytic converter (responsible for reducing $\mathrm{CO}$ and $\mathrm{NO}_{\mathrm{x}}$ emissions in passengers' vehicles), causing catalyst deactivation and reducing engine efficiency $[5,18]$.

$\mathrm{N}$-containing compounds pose issues in catalyst selection and process development and operation in oil upgrading and refining [4]. The main problems associated with nitrogen are: (i) 5-membered rings containing nitrogen compounds, such as pyrrolic compounds, are prone to free radical addition reactions, forming heavier products or gums that highly compromise storage stability [4]; (ii) the presence of basic nitrogen compounds leads to the deactivation of acid catalysts through acid-base reactions [4]; (iii) the presence of basic nitrogen compounds leads to salt precipitation (due to acid-base reactions with carboxylic acids), resulting in equipment fouling and even corrosion if water is present under high-temperature operation [4]; (iv) metal coordination is indirectly controlled by nitrogen, and nitrogen is therefore indirectly responsible for metal deposition, leading to equipment fouling [4]; (v) nitrogen competes with other compounds for active sites on catalyzed processes, such as the HDS process. Thus, the presence of nitrogen compounds hinders the removal of sulfur compounds [4]. Therefore, it is preferable to remove nitrogen compounds, especially before the refining processes. 


\subsection{Legislation}

The maximum sulfur content allowed for transportation fuels (gasoline and diesel) has become stricter in the last years worldwide. Currently, the EU allows only $10 \mathrm{ppm}$ of sulfur in diesel and gasoline [19]. In contrast, the US limits of sulfur content for gasoline and diesel are 10 [20] and $15 \mathrm{ppm}$ [21], respectively. Figure 5 shows the evolution of the allowed content of sulfur in gasoline (Figure 5a) and diesel (Figure 5b) in the last decades. As observed, EU was the first to regulate the content of sulfur in gasoline to $150 \mathrm{ppm}$ in 2000, followed by Australia (500 ppm in 2002) > Canada (150 ppm in 2003) > US (120 ppm in 2004) > India (500 ppm in 2005) > China (500 ppm in 2006) > Japan (10 ppm in 2007) > Brazil (50 ppm in 2010) > Russia (150 ppm in 2013). However, the most restricted content of sulfur in gasoline (10 ppm) was first established by Japan in 2007, followed by Canada and EU (2009) > Russia (2016) > US and China (2017) > India (2020) and Australia (2027, to be implemented). For diesel (Figure 5b), Japan was also the first to limit the S-content in 10 ppm in 2007, followed by EU and Australia (2009), Brazil (2013), Russia (2016), China (2017), and India (2020) (the US and Canada establish the value of $15 \mathrm{ppm}$ ). Nitrogen is not directly regulated in permitted content but indirectly by allowed $\mathrm{NO}_{\mathrm{x}}$ emissions, gum content, storage, and thermal stability [4].

(a)

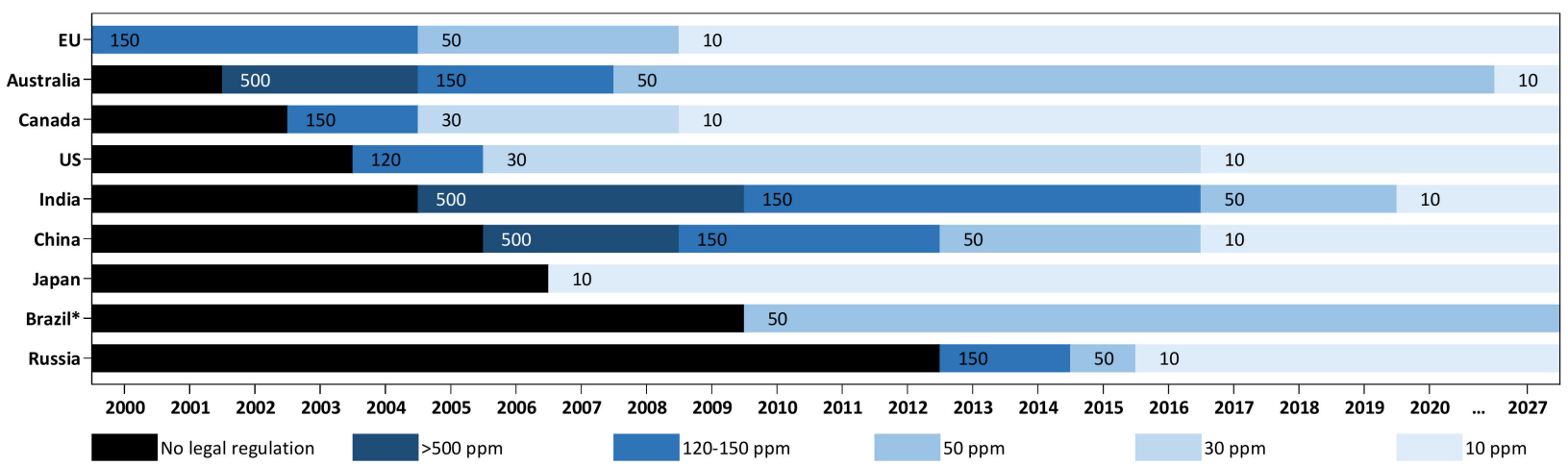

(b)

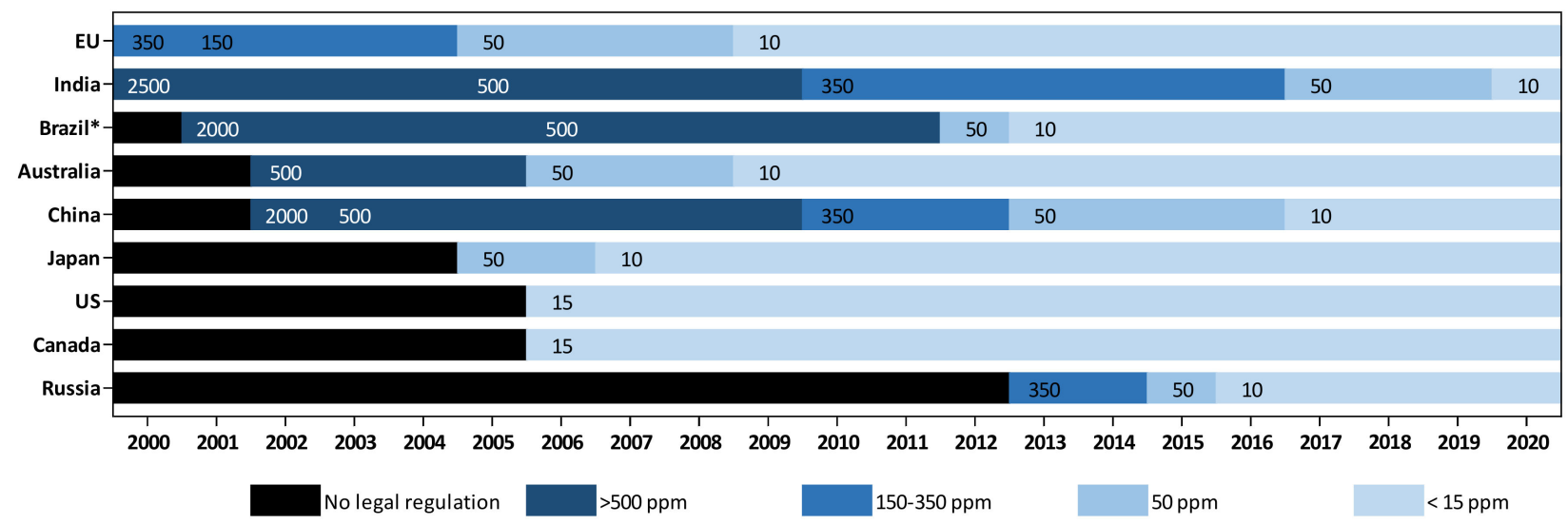

Figure 5. Evolution of the limit of sulfur content in (a) gasoline and (b) diesel, according to the implementation date. ${ }^{*}$ Refers to metropolitan areas. Source: Miller and Façanha (2014) [22], TransportPolicy.net [23-26], United States Environmental Protection Agency [20], Australian Government [27], Euro V [28], Miller, and Jin (2019) [29].

\section{Processes for Removal of Sulfur and Nitrogen from Fuels}

Environmental issues and restrictive legislation have spiked the interest desulfurization and denitrogenation technologies since 1951 (Figure 6). The most studied strategies are classified in conventional processes, as HDS and HDN, and in more novel approaches, mainly ODS and ODN. 


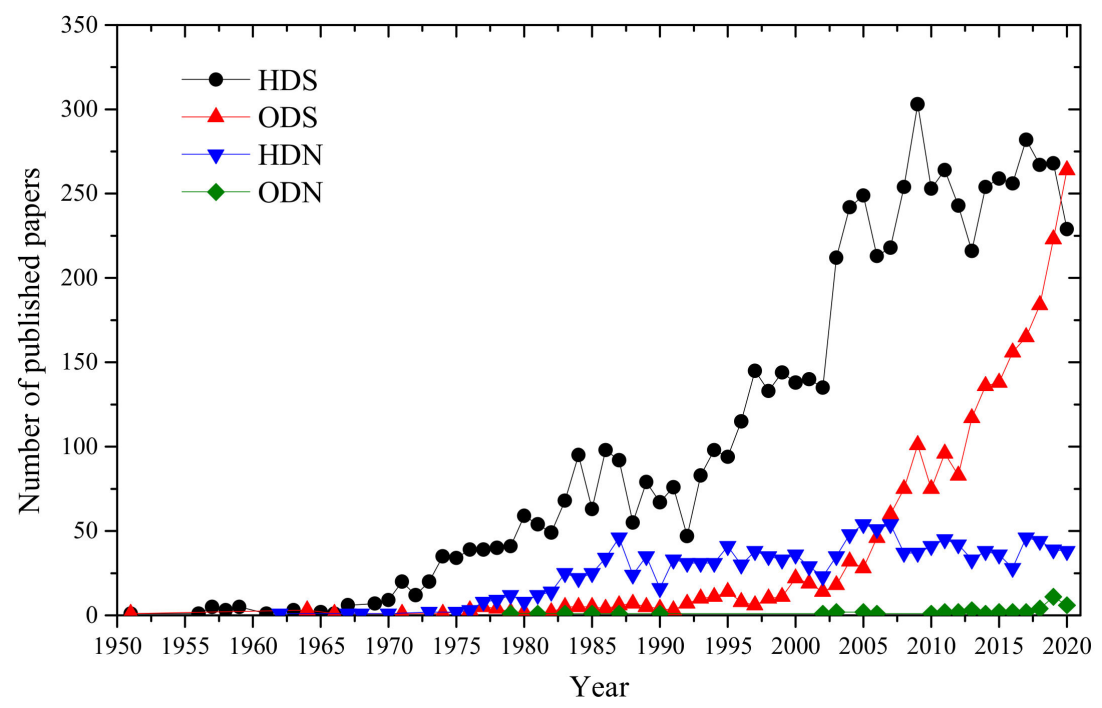

Figure 6. Papers published on HDS, HDN, ODS, and ODN over the years (source: SCOPUS with the keywords "hydrodesulfurization," "hydrodenitrogenation," “oxidative desulfurization," and "oxidative denitrogenation," respectively, dated August 2021).

\subsection{Hydrodesulfurization (HDS) and Hydrodenitrogenation (HDN)}

Several processes based on the reaction between hydrocarbons and hydrogen are used in the petroleum industry, such as hydrotreating, hydrocracking, and hydrogenation [30]. Hydrotreating refers to removing undesired species, such as sulfur, nitrogen, oxygen, and metal impurities, from petroleum fractions [30] by hydrogenolysis of $C-X$ bonds, where $X$ can be $\mathrm{S}, \mathrm{N}, \mathrm{O}$, or metal. The net result is the formation of $\mathrm{C}-\mathrm{H}$ bonds (hydrogenation) and $\mathrm{H}-\mathrm{X}$ bonds [30]. The chemical reaction of fixating a hydrogen atom onto a hydrocarbon double bond, known as hydrogenation, using nickel catalysts, was first described in 1897. However, only in the mid-50s, the first noble metal catalyst was developed, and the HDS process commercialized [31]. Several HDS processes have been commercialized from then on, and all petroleum refineries worldwide have at least one hydrotreating unit [31].

The hydrotreatment of nitrogen-, sulfur- and oxygen-containing compounds will lead to ammonia $\left(\mathrm{NH}_{3}\right)$, hydrogen sulfide $\left(\mathrm{H}_{2} \mathrm{~S}\right)$, and water, respectively [31]. Oxygencontaining compounds are much more reactive than nitrogen- and sulfur-containing compounds towards hydrotreatment, and thus hydrotreating is not specifically developed to remove O-compounds [32]. Most processes are designed to deal with S-compounds due to their hazardous effect on downstream processes. The removal of $\mathrm{S}, \mathrm{N}$, and other impurities co-occur in refinery conditions [33]. Thus, $\mathrm{N}$-containing impurities are also removed during hydrotreatment processes designed to remove sulfur [32], although nitrogen compounds are much less reactive and hard to remove than sulfur [4].

Different sulfur compounds have different rates of HDS [32]. Mercaptans, sulfides, and disulfides are highly reactive towards HDS under mild conditions. On the other hand, 5-membered ring compounds containing sulfur (thiophenes) are very little reactive towards HDS, and the reactivity decreases as the number of rings (in the range 1-3 rings) increases [32]. However, the tendency reverses for structures containing four or more rings, and the reactivity increases as the number of rings increases [32]. The distinct behavior is that there is more than one pathway to remove sulfur from a molecule. Depending on the sulfur compound, one pathway may be more relevant than the other [32]. The order of reactivity of common organosulfur compounds towards HDS can be seen in Figure 7. 


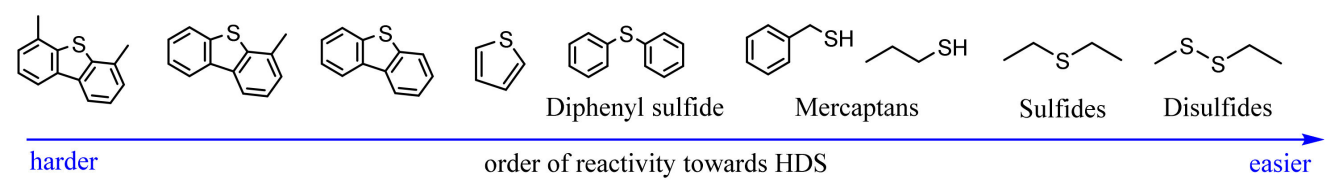

Figure 7. Order of reactivity of different S-containing compounds. Adapted from Rajendran et al. (2020) [34].

Analogous to thiophenes, nitrogen-containing compounds require a step of hydrogenation before removal of $\mathrm{N}$, and thus, the $\mathrm{H}_{2}$ partial pressure is crucial [33]. Nitrogen removal for pyridinic structures is more complex than for thiophene structures. One single bond and one double bond require to be broken [4]. In contrast, thiophenes only require two single bonds to be broken [4]. The presence of alkyl groups tends to decrease the reactivity of the S-compounds due to steric hindrance. The closer the alkyl group is to the sulfur or nitrogen atom, the stronger the effect on the reactivity [33]. Further information regarding the effect of temperature, catalysts, and other parameters in HDS and HDN processes may be found elsewhere [35].

Thus, different operating conditions may be required depending on the compounds present in the petroleum fraction. Table 2 shows some common hydrotreatment operational conditions for different fractions of petroleum. Heavier fractions tend to be richer in thiophene and N-containing compounds, and harsher conditions are required to remove those compounds. Increasing operational conditions affects a series of parameters in diesel and gasoline. Oxygen, benzene, aromatics and olefin contents, vapor pressure, and boiling range can be compromised during gasoline range hydrotreatment. In contrast, the compromised parameters for diesel are cetane number, density, and content on polynuclear aromatics and distillation 95\% point for diesel [36]. Besides that, hydrogen is a very expensive reactant, and process efficiency is highly limited by the reactivity of certain sulfur compounds, by the deactivation of catalysts due to coke formation, and by the presence of $\mathrm{H}_{2} \mathrm{~S}$ [7]. Thus, alternatives to HDS and HDN processes need to be sought.

Table 2. Process conditions for different fractions of petroleum for HDS.

\begin{tabular}{lcccc}
\hline Feed & $\begin{array}{c}\text { Temperature } \\
\left({ }^{\circ} \mathbf{C}\right)\end{array}$ & $\begin{array}{c}\text { Hydrogen Partial } \\
\text { Pressure (bar) }\end{array}$ & $\begin{array}{c}\text { Hydrogen } \\
\text { Consumption (wt. \%) }\end{array}$ & $\begin{array}{c}\text { Catalyst Life } \\
\text { Span (Years) }\end{array}$ \\
\hline Naphta & $260-300$ & $5-10$ & $0.05-0.10$ & $3-10$ \\
Kerosene & $300-340$ & $15-30$ & $0.10-0.20$ & - \\
Gas oil & $320-350$ & $15-40$ & $0.30-0.50$ & - \\
Residue & $340-425$ & $55-170$ & $1.50-2.00$ & $0.5-1$ \\
\hline
\end{tabular}

Source: adapted from Fahim et al. (2010) [30] and Speight (2011) [31].

\subsection{Alternative Routes to Remove Sulfur and Nitrogen}

There is a wide range of alternatives to remove sulfur and nitrogen from liquid fuels. There are approaches based on liquid-liquid extraction (extractive desulfurizationEDS) using traditional solvents, deep eutectic solvents (DES) or ionic liquids (ILs) [37-39], adsorption (adsorptive desulfurization-ADS) [40], microorganisms (biodesulfurizationBDS) [41], and the oxidation of the undesired compounds (e.g., oxidative desulfurizationODS). ODS is a promising technology since it operates under milder temperature and pressure conditions $\left(25-140{ }^{\circ} \mathrm{C}, 1-2\right.$ bar) than HDS $\left(260-425^{\circ} \mathrm{C}, 5-160\right.$ bar). Thus, ODS does not require specialized reactors to operate at high pressure and temperature conditions. Catalyst and solvents can be mostly recycled, and the refractory-towards-HDS sulfur compounds are easily oxidized, leading to deep desulfurization [7]. Finally, ODS does not cause olefins saturation, nor does it result in loss of octane content [42] or other fuel parameters as those affected during HDS under harsher conditions. 


\section{Oxidative Desulfurization (ODS) and Denitrogenation (ODN)}

The ODS process is based on the oxidation of sulfur-containing compounds towards their corresponding sulfoxides and sulfones (as shown in Figure 8) [43], followed by the extraction or adsorption of the oxidized compound. Thus, ODS is, in fact, a two-step process: (i) oxidation and (ii) extraction (or adsorption) $[7,43]$ of the oxidized compounds. In some cases, especially with ILs, which can act as catalysts and extractants in ODS, an alternative system, extractive-catalytic oxidative desulfurization (ECODS), is introduced [44].

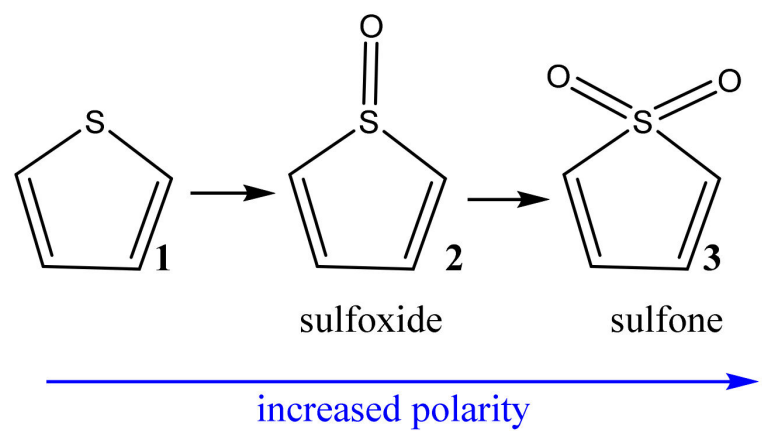

Figure 8. Oxidation of thiophene (Th) 1 to a sulfoxide (thiophene 1-oxide 2 ) and a sulfone (thiophene 1,1-dioxide 3).

Due to the strong affinity of sulfur for oxygen, oxidation of hydrocarbons is not expected to occur in the usual operating conditions of ODS, thus promoting the selective oxidation of organosulfur compounds without affecting C-C bonds [34]. The reactivity of a sulfur compound towards oxidation depends on the electron density around the $\mathrm{S}$ atom. The higher the electron density, the more prone the electrophilic attack on the oxygen is [7] and the higher is the reaction rate towards the formation of sulfones [45]. However, the order of reactivity seems to depend significantly on the type of oxidant, catalyst, and operating conditions. Nevertheless, there is no organosulfur category that is entirely unreactive towards ODS [34].

The ODN process, in turn, has not been as extensively studied as ODS (as demonstrated in Figure 6). There is a broader range of possible reaction products than ODS during the oxidation of $\mathrm{N}$-containing compounds due to the several bonds of $\mathrm{N}$-compounds that are prone to oxidation [46]. For instance, quinoline $(\mathrm{QN})$ oxidation gives reaction intermediates: 5-hydroxyquinoline and 8-hydroxyquinoline are the major products. However, trace quantities of 3-, 6- and 7-hydroxyquinoline are also observed [47]. Selectivity towards one product or the other may be tuned by controlling the reaction conditions [46].

Several oxidants have been reported in the literature for ODS and ODN, such as hydrogen peroxide, organic peracids, oxygen, and ozone, among others [7]. The oxidized compounds have an increased relative polarity compared to their parent compounds, and thus their extraction is facilitated [5]. The oxidized compounds are more commonly removed through liquid-liquid extraction rather than through adsorption. Adequate extractants should fulfill a few criteria: they should be immiscible with the oil phase, they should be able to dissolve sulfones and sulfoxides, differences in density may exist to facilitate the separation between oil and extractant, and not impact the fuel properties, among others [34]. Some extractants found in the literature are acetonitrile (ACN), methanol $(\mathrm{MeOH})$, ethanol $(\mathrm{EtOH})$, diethyl ether $\left(\mathrm{Et}_{2} \mathrm{O}\right)$, dimethylformamide (DMF), methyl cyanide, carbon tetrachloride $\left(\mathrm{CCl}_{4}\right)$, and ILs. Aqueous solutions of $\mathrm{H}_{2} \mathrm{O}_{2}$ (used as an oxidant) also are applied as extractants on their own. 
As previously mentioned, both ODS and ODN are primarily conducted in a two-step process. However, in order to cut costs and accelerate the processes, one-pot approaches are increasingly sought. In one-pot approaches, extraction occurs concomitantly to oxidation and, hence, the extractant must be present during the oxidation step. Proper extractants are immiscible with the oil phase and, thus, one-pot approaches are commonly conducted in a biphasic medium. Biphasic systems have some advantages over traditional homogeneous systems. Biphasic systems allow conducting reactions with reactants with distinct solubility behaviors. They allow an easier separation between reactants, products, and catalysts, and the reactions to be conducted with incompatible substances, avoiding interferences $[48,49]$.

However, biphasic systems display some issues. The main issue is the low interfacial area between the phases, hindering reaction $[48,50]$. An alternative is emulsifying the biphasic medium [48], as emulsion systems significantly improve the interfacial area. Emulsifying requires the use of a surfactant or of solid particles that allow the stabilization of Pickering emulsions. Pickering emulsions are an exciting template since the solid particles act as stabilizers and can also assume the role of catalysts. This approach is often referred to as Pickering Interfacial Catalysis (PIC) [50,51].

A wide range of solid particles can be used in the stabilization of Pickering emulsions, such as silica [52], magnetic particles [53], and carbon-based materials [54,55], among others. Pickering emulsions are affected by a range of conditions $(\mathrm{pH}$, type of oil, ratio between the 2 phases, and concentration of particles, among others). One of the most interesting strategies to adjust emulsion formation and stability is to tune the amphiphilic character of the solid particles [56]. Amphiphilic materials display both hydrophilic and hydrophobic character and thus are wetted by more than one phase. As expected, particles wetted by more than one phase should allow easier emulsion formation and more stable emulsions [56]. Thus, amphiphilic materials should be advantageous when working under biphasic systems, especially in PIC-like approaches under emulsified systems.

Numerous catalysts have been applied for ODS and ODN purposes. However, discussing possible catalysts rather than carbon materials is not the aim of this review. Further information on other ODS catalysts may be found elsewhere [34,42,44,57]. Carbon-based materials, i.e., the focus of this review, have been widely used in ODS and ODN, either by composing hybrid materials or as catalysts on their own. Carbon-based materials display several advantages in oxidative processes. Their ability to form oxidizing species (such as hydroxyl radicals) from oxidant sources (such as hydrogen peroxide) has been widely studied [58-62]. They are proven catalysts for oxidation reactions in the liquid phase, either as catalysts on their own or in hybrid forms, such as in water and wastewater remediation [63-67]. Thus, applying those materials in the oxidative removal of sulfur and nitrogen from liquid fuels is a natural extension. Carbon-based materials can be synthesized from various precursors, including waste materials [68-70], and through several synthesis procedures [68-75]. Table 3 summarizes the main carbon-based materials that will be discussed in the following sections, along with some common carbon sources and synthesis routes. The column with the reference will lead the reader to the appropriate literature regarding the preparation of the mentioned materials.

In the following section, papers related to ODS and ODN of liquid fuels (simulated or real matrix) using strictly carbon-based materials in hybrid forms or as catalysts on their own will be presented. Furthermore, when appropriate, a distinction between the papers that use a two-step process, a biphasic system, and a PIC-type approach will also be made. 
Table 3. Examples of carbon-based materials, and respective carbon precursors, synthesis routes and characteristics, studied for ODS and ODN purposes.

\begin{tabular}{|c|c|c|c|c|}
\hline $\begin{array}{c}\text { Carbon-Based } \\
\text { Material }\end{array}$ & Carbon Source & Synthesis Procedures & Characteristics & Ref. \\
\hline $\begin{array}{c}\text { Carbon Nanotube } \\
\text { (CNT) }\end{array}$ & $\begin{array}{l}\text { Plastic waste, coal, } \\
\text { biomass, } \\
\text { hydrocarbon gases. }\end{array}$ & $\begin{array}{l}\text { Chemical Vapor Deposition } \\
\text { (CVD), laser ablation, arc } \\
\text { discharge, sonochemical, } \\
\text { electrolysis }\end{array}$ & $\begin{array}{l}\text { High Mechanical Strength }(50-500 \mathrm{G} \text { Pa), Electrical Conductivity } \\
\left(3000-3500 \mathrm{~W} \mathrm{~m}{ }^{-1} \mathrm{~K}^{-1} \text {, and Thermal Stability }\left(>700^{\circ} \mathrm{C}\right) \text {. Diameters }\right. \\
\text { from } 0.4 \text { to } 40 \mathrm{~nm} \text {. }\end{array}$ & [70-72] \\
\hline $\begin{array}{l}\text { Graphene Oxide } \\
\text { (GO) and } \\
\text { Reduced-GO (rGO) }\end{array}$ & $\begin{array}{l}\text { Plastic waste, } \\
\text { hydrocarbon gases. } \\
\text { Graphite }\end{array}$ & $\begin{array}{l}\text { Thermal decomposition, } \\
\text { CVD, flash joule heating } \\
\text { Electrochemical exfoliation }\end{array}$ & $\begin{array}{l}\text { High electrical and thermal conductivity (up to } \sim 5000 \mathrm{~W} \mathrm{~m}^{-1} \mathrm{~K}^{-1} \text { ), } \\
\text { strongest material ever measured (Young's module } 1 \mathrm{~T} \mathrm{~Pa} \text { ), good } \\
\text { stretchability, high surface area (theoretical calculations predict a } \\
\text { value of } 2630 \mathrm{~m}^{2} \mathrm{~g}^{-1} \text { for monolayer graphene), high chemical and } \\
\text { thermal stability. }\end{array}$ & {$[68,73]$} \\
\hline $\begin{array}{l}\text { Carbon Nitride } \\
\quad\left(\mathrm{g}-\mathrm{C}_{3} \mathrm{~N}_{4}\right)\end{array}$ & $\begin{array}{l}\text { Triazine and } \\
\text { heptazine } \\
\text { derivatives, cyanide, } \\
\text { urea, melamine. }\end{array}$ & $\begin{array}{l}\text { Solid-state reaction, } \\
\text { hard-template method, } \\
\text { chemical exfoliation, } \\
\text { hydrothermal, thermal } \\
\text { decomposition }\end{array}$ & Tunable optoelectronic properties and metal-free semi-conductor. & {$[74,75]$} \\
\hline $\begin{array}{c}\text { Activated Carbon } \\
\text { (AC) }\end{array}$ & $\begin{array}{l}\text { Biomass, } \\
\text { C-containing wastes } \\
\text { (e.g., plastic, food, } \\
\text { and agricultural } \\
\text { residues), coal, } \\
\text { anthracite, peat. }\end{array}$ & $\begin{array}{l}\text { Pyrolysis followed by } \\
\text { chemical or physical } \\
\text { activation }\end{array}$ & $\begin{array}{l}\text { High surface area (usually } \mathrm{s}_{\text {bet }}>500 \mathrm{~m}^{2} \mathrm{~g}^{-1} \text { ), highly developed } \\
\text { internal pore structure, presence of functional groups, especially } \\
\text { oxygenated, wide variety of ACS, usually low cost. }\end{array}$ & [69] \\
\hline
\end{tabular}

\section{Carbon Materials in ODS}

The following sections will present the studies related to carbon materials in ODS systems, breaking them into three main sections: (i) hybrid materials containing carbonaceous structures, (ii) carbon-based materials as catalysts on their own, and (iii) systems applying amphiphilic catalysts containing carbon in their structure. As seen in Figure 9, most papers (73\%) reported in the literature are related to applying carbon-based materials forming either hybrid materials or as supports for active centers. Fewer papers deal with amphiphilic materials that contain carbon in their structure $(15 \%)$ or as catalysts on their own $(12 \%)$.

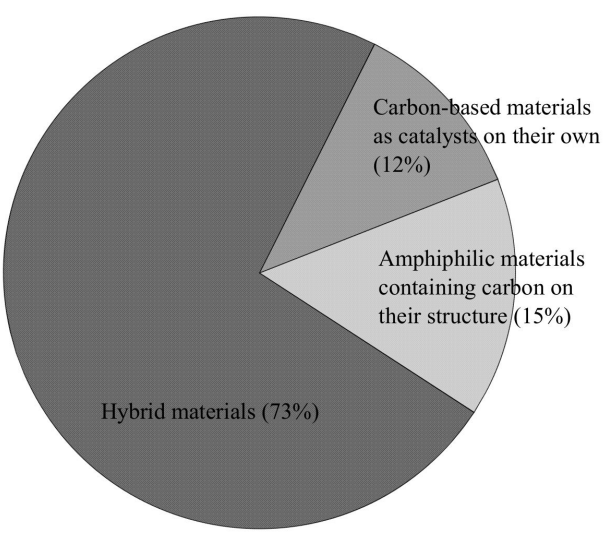

Figure 9. Percentage of published papers regarding the application of (i) hybrid materials containing carbonaceous structures, (ii) carbon-based materials as catalysts on their own, and (iii) systems applying amphiphilic catalysts containing carbon in their structure.

\subsection{Carbon Supports and Hybrid Catalysts}

One of the advantages of carbon materials is that they can be combined with other materials to prepare composites or hybrid catalysts. Thus, most of the papers related to ODS with carbon materials have applied them in hybrid forms. As discussed before, ODS can be conducted in various systems, such as two-step processes, biphasic systems, under the emulsified form, and solvent-free, among others. Hence, the different systems are separated into different sections. 


\subsubsection{Two-Step Systems}

The papers related to ODS reactions using carbon hybrid materials under a two-step process are gathered in Table 4. As observed, several combinations of hybrid materials consisting of phosphotungstic acid $\left(\mathrm{H}_{3} \mathrm{PW}_{12} \mathrm{O}_{40}, \mathrm{HPW}\right)$, iron, palladium, molybdenum, and titanium active metal phases with $\mathrm{g}-\mathrm{C}_{3} \mathrm{~N}_{4}, \mathrm{GO}$ and its reduced derivative (rGO), CNTs, and $\mathrm{AC}$ as supports/hybrids. The catalytic activities of these hybrid materials have been assessed in ODS of solutions with initial sulfur concentrations ([S $\left.]_{0}\right)$ ranging from 100 to 9400 ppm using $\mathrm{H}_{2} \mathrm{O}_{2}$ as oxidant under mild conditions $\left(25-80^{\circ} \mathrm{C}\right)$ and achieving sulfur removals higher than $90 \%$. In general, most authors have not justified the role of the carbon structure in these runs [76-82], with a few exceptions.

Huang et al. (2017) [83] performed ODS of a simulated fuel using dibenzothiophene (DBT) dissolved in n-octane ([S $\left.]_{0}=100 \mathrm{ppm}\right)$ using an N-doped onion-like (NOLC) supported HPW. They have obtained high conversions $(>90 \%)$, which were maintained for up to 10 reuse cycles. They attributed the excellent results to the excellent dispersion of the active phase (HPW) in the NOLC structure. The surface of NOLC displayed a high content of oxygenated groups, which can interact with HPW, strengthening the HPWsupport interaction. In turn, the HPW dispersion is improved, boosting the reaction [75]. Rafiee, Shahbazirad, and Khodayari (2017) also found that an increased dispersion of $\mathrm{HPW}$ over $\mathrm{TiO}_{2} / \mathrm{g}-\mathrm{C}_{3} \mathrm{~N}_{4}$ resulted in higher desulfurization rates of a simulated fuel (DBT $\left(C_{0}=500 \mathrm{ppm}\right)$, BT $\left(C_{0}=250 \mathrm{ppm}\right)$ and $\mathrm{Th}\left(C_{0}=250 \mathrm{ppm}\right)$ in EtOH/n-heptane $)$ and for a real oil $\left([\mathrm{S}]_{0}=500\right.$ or $\left.1900 \mathrm{ppm}\right)$ [84].

Abdelrahman et al. (2018) [85] also highlighted the high dispersion of $\mathrm{Mo}_{132}$ as one of the reasons for the high activity of a hybrid catalyst supported on GO in the ODS of DBT, benzothiophene (BT) or 4,6-dimethyldibenzothiophene (4,6-DMDBT) as model compounds dissolved in dodecane ( $[\mathrm{S}]_{0}=500 \mathrm{ppm}$ ). They obtained conversions of sulfur compounds higher than $94 \%$ regardless of the model compound and were able to maintain the activity up to 10 cycles. Besides the high dispersion of the active phase, GO was also found to increase the adsorption of sulfur compounds due to the Lewis acidic character of its defect sites. The adsorption of sulfur compounds in the catalyst structure approximates the $\mathrm{S}$ compound and the oxidant, thus enhancing the oxidation reaction [85].

\subsubsection{L-L Biphasic Systems}

Tables 5-8 show the studies related to the application of carbon-based hybrid materials in the ODS of a range of sulfur compounds in the biphasic system, i.e., systems where oxidation and extraction occur simultaneously. Each table shows studies using different allotropes of carbon. Not all authors have studied the influence of the carbon structure in the proposed systems [86-89].

Rongxiang et al. (2017) performed ODS of a simulated fuel (DBT in n-octane) using a hybrid catalyst of $\mathrm{WO}_{3}$ supported over $\mathrm{g}-\mathrm{C}_{3} \mathrm{~N}_{4}$. They have found that the most relevant contribution of the carbon structure is related to its high surface area, which in turn allows for a higher dispersion of the active phase [90]. The higher surface area increases the adsorption of sulfur compounds, whereas the higher dispersion impacts the desulfurization performance [90]. The high surface area of AC is also suggested by Xiao et al. (2014) as one of the reasons for the increased activity of HPW supported over AC compared to unsupported HPW in the ODS of thiophene (Th) in a mixed solvent simulating a gasoline matrix [91]. Other authors have also pointed out the high surface area and related high dispersion as relevant contributions of carbonaceous structures to the catalytic activity [92-96]. In contrast, the agglomeration of active centers was linked to a decrease in catalytic activity [97].

Hou et al. (2018) [98], on the other hand, reported that the surface area of the catalyst is not the only relevant parameter for ODS of a simulated fuel (DBT in n-octane) using a g- $\mathrm{C}_{3} \mathrm{~N}_{4}$ supported $\mathrm{MoO}_{2}$ catalyst. They also observed that the active phase concentration, or loading, is essential information. While increasing the amount of loaded $\mathrm{MoO}_{2}$ increases the number of active sites, it significantly reduces the surface area of the catalysts, resulting 
in poor dispersion of the active sites. On the other hand, low loading of active center results in a catalyst with a high surface area but a low number of active sites. Thus, finding the optimum combination between loading of active phase and maintaining high surface area is a crucial step [98].

In 3D-carbonaceous structures, the surface area was also pointed out as a critical parameter. Ye et al. (2020) have confined $\mathrm{MoO}_{\mathrm{x}}$ in a 3D-macroporous carbon structure and applied these hybrid materials in ODS of a simulated fuel (BT, DBT, and 4,6-DMDBT in $\mathrm{n}$-octane). One of the reasons for the high activity of the materials (conversions higher than $85 \%$ in 75 min of reaction) was attributed to the high surface area of the 3D-carbon structure, which resulted in a fast mass transfer to the active sites confined within the structure [99]. Zhu et al. (2020) also have observed that the 3D structure of carbon spheres (3D-CS) is beneficial to an increased mass transfer during oxidative desulfurization [97]. Bhadra et al. (2017) also highlighted a fast mass transfer resultant from mesoporosity of the catalyst as an important contributor to the high activity of $\mathrm{a} \mathrm{TiO}_{2}-\mathrm{C}$ in ODS of a simulated fuel (Th, BT, DBT or 4,6-DMDBT in n-octane, [S $]_{0}=1000 \mathrm{ppm}$ ) [92].

Other authors have pointed out that carbon structures play an important role through adequate adsorption of sulfur compounds, which can be ascribed to an increase in DBT concentration in the vicinity of active catalytic centers [100]. Wang et al. (2010) observed that the main role of CNT in a hybrid catalyst consisting of CNT and a phosphotungstic acid was to enhance the transfer of DBT to the active center by adsorption, facilitating the oxidation of DBT [101]. Xing et al. (2017) observed that increasing the calcination temperature of a $\mathrm{CoWO}_{4} / \mathrm{g}-\mathrm{C}_{3} \mathrm{~N}_{4}$ resulted in an enhanced surface area and adsorption ability towards DBT [102]. Other authors have also highlighted the adsorption capacity of carbonaceous materials, either towards DBT and other sulfur compounds [90,99,100,103] or towards the oxidation products [104].

Yu et al. (2010) also observed that the adequate adsorption of DBT into the carbon structure was an essential contribution of the carbon-based support in an HPW / AC catalyst [105]. Their reasoning is that increased adsorption of DBT leads to a higher collision probability between DBT and active oxygen species from the decomposition of $\mathrm{H}_{2} \mathrm{O}_{2}$ that takes place in the active center (HPW). The carbon surface also influences the resonancestabilization of these active oxygen species, boosting oxidation. Moreover, due to the hydrophobicity of AC, it can be adequately dispersed in the oily phase or placed in the interface between the oily and polar phases, acting as a phase transfer agent [105]. Kermani et al. (2018) also found that the combination between adsorption capacity towards DBT and adequate lipophilicity of AC structure was an essential feature of the composite $\mathrm{Mo}_{132} / \mathrm{AC}[106]$.

In an ultrasound-assisted ODS (UAODS) of a simulated fuel with an $\mathrm{HPW} / \mathrm{AC}$ as the catalyst, Liu et al. (2014) also identified the increased adsorption of DBT and the ability of the catalyst to act as a phase transfer agent as important features arising from the AC support [107]. However, they have also pointed out that the AC structure plays another relevant role in UAODS: the high surface area was also correlated to a higher cavitation activity in UAODS, boosting reaction rates [107,108].

Functional groups on the carbon material can impact the coordination of active species (metallic centers) [109-111]. Dini, Afsharpour, and Tabar-Heydar (2019) argued that the oxidation of DBT undergoes an electrophilic attack of the peroxo group (LUMO) on the catalyst surface to the sulfur compound (HOMO) [110]. Thus, efficient oxidation needs to overcome the LUMO-HOMO barrier. The functional groups on the support surface (in this case, CNTs) affect the coordination of the metal-active species (Mo). This geometry boosts the electron density of peroxo groups and increases the HOMO energy level. By increasing the energy level of HOMO, the gap between HOMO-LUMO decreases, and oxidation is facilitated [110,111].

Other authors have correlated the activity of hybrid materials to an increased electron transfer between carbon structure and active phase, especially in doped carbon-based materials. Bhadra, Khan, and Jhung (2019) observed that N-doped graphitic carbon-supported 
Co resulted in a more effective electron transfer, which could be helpful for oxidation and reduction reactions [112]. Liao et al. (2019) observed that the strong interaction between HPW and rGO enhanced electron mobility and, consequently, the reaction rate [113].

Wang et al. (2020) [95] and Zhao et al. (2017) [96] have proposed that g- $\mathrm{C}_{3} \mathrm{~N}_{4}$ was able to activate $\mathrm{H}_{2} \mathrm{O}_{2}$ and form hydroxyl radicals $\left(\mathrm{HO}^{\bullet}\right)$. Moreover, the carbon structure was also found to avoid the leaching of active species [113].

\subsubsection{Other ODS Systems}

Table 9 displays a miscellaneous of other ODS systems, whereas Table 10 displays photocatalytic ODS systems. Similar to what was observed earlier, the developed surface area and the structure of pores in carbon materials, leading to well-dispersed active phases, were found as a critical contribution of carbon structures [114-118]. Xun et al. (2020) [119] also highlighted the dispersion of $\mathrm{TiO}_{2}$ over a graphite carbon (GC) as a relevant factor for the ODS of a simulated fuel (DBT, 4-methyldibenzothiophene (4-MDBT) and 4,6-DMDBT) dissolved in n-octane, $[\mathrm{S}]_{0}=500 \mathrm{ppm}$ ). However, they also observed that the dispersion is related to the amount of active phase dispersed on the support. Upon increasing $\mathrm{TiO}_{2}$ content over $10 \mathrm{wt} . \%$, the catalytic activity of the hybrid catalyst decreased due to the agglomeration of $\mathrm{TiO}_{2}$ particles. Thus, loading the proper amount of the active phase is an important step. The synergistic effect between the support and the active centers is the main reason a catalyst displays outstanding properties in ODS systems [119]. Gao et al. (2020) [120] found that the increased surface area was also associated with a higher collision probability between sulfur compounds and the catalyst. They observed that the activity of the polyoxometalate-based IL supported over a series of carbon materials decreased accordingly to the surface area of the support $\left(\mathrm{P}\left[\mathrm{C}_{2} \mathrm{VP}\right] \mathrm{MoV} / \mathrm{AC}\left(170 \mathrm{~m}^{2} \mathrm{~g}^{-1}\right)>\mathrm{P}\left[\mathrm{C}_{2} \mathrm{VP}\right] \mathrm{MoV} / \mathrm{CA}\right.$ $\left.\left(157 \mathrm{~m}^{2} \mathrm{~g}^{-1}\right)>\mathrm{P}\left[\mathrm{C}_{2} \mathrm{VP}\right] \mathrm{MoV} / \mathrm{CNT}\left(93 \mathrm{~m}^{2} \mathrm{~g}^{-1}\right)>\mathrm{P}\left[\mathrm{C}_{2} \mathrm{VP}\right] \mathrm{MoV} / \mathrm{GO}\left(10 \mathrm{~m}^{2} \mathrm{~g}^{-1}\right)\right)$ [120]. This observation highlights the importance of a developed surface area to a well-dispersed active phase and high desulfurization rates.

Carbon-based materials were also found to accelerate the electron transfer for different active phase-support pair materials, such as $\mathrm{MoO}_{2} / \mathrm{g}-\mathrm{C}_{3} \mathrm{~N}_{4}$ [115], $\mathrm{FePc}\left(\mathrm{NO}_{2}\right)_{3}-\mathrm{CF}$ [118], $\mathrm{V} / \mathrm{P}$-doped g- $\mathrm{C}_{3} \mathrm{~N}_{4}$ [121], VO- $\mathrm{MoO}_{2} @ \mathrm{~N}$-doped CNT [122], considering different oxidants (TBHP [115,121], $\mathrm{O}_{2}$ [118] and CHP [122]), which enhances oxidative desulfurization rate. Chen, Ren, and Yuan (2020) observed that the rate-determining step in the ODS of DBT using V supported over a P-doped g- $\mathrm{C}_{3} \mathrm{~N}_{4}$ material is the electron transfer, and thus an enhanced electron transfer due to $\mathrm{P}$ doping greatly improved oxidation [121]. They also observed that P-doping g- $\mathrm{C}_{3} \mathrm{~N}_{4}$ enhanced the electron transfer, resulting in a more efficient ODS process [121].

Some authors have reported that carbonaceous materials favor electron-hole separation [123-127] (cf. Table 10), thus benefiting the photocatalytic activity of those hybrid materials. Li et al. (2017) claimed that the narrower bandgap of $\mathrm{g}-\mathrm{C}_{3} \mathrm{~N}_{4}$ allows the application of visible light [124]. Furthermore, the well-matched band structures between support and active phase $\left(\mathrm{CeO}_{2}\right)$ favor the ready transfer of electrons generated in the surface of the support to the surface of $\mathrm{CeO}_{2}$ to avoid the recombination of photo-generated electrons and holes effectively. Thus, the electrons can react with hydrogen peroxide to form hydroxyl radicals. They observed that the holes might also participate in the reaction, although contributing much less than electrons, due to the weak potential of the valence band of g- $\mathrm{C}_{3} \mathrm{~N}_{4}(1.79 \mathrm{eV})$ compared to the redox potential of the $\mathrm{OH}^{-} / \mathrm{HO} \bullet$ pair $(1.99 \mathrm{eV})$ [124]. Ma et al. (2017) also found that the use of carbon quantum dots (CQD) improved the efficiency of the use of visible light [125].

In general, most ODS systems require an extractant phase and a catalyst to remove the oxidized intermediates. However, in a few processes, the hybrid material can act as a catalyst to oxidize sulfur compounds and adsorbents for the oxidized products in a solvent-free approach. Jiang et al. (2017) immobilized a polyoxometalate-based IL in graphite carbon and tested this hybrid catalyst in the solvent-free ODS of a simulated fuel. A $100 \%$ removal of DBT in the model oil was observed, whereas only DBT sulfone 
$\left(\mathrm{DBTO}_{2}\right)$ was detected in the catalyst phase. The high efficiency of the process was ascribed to the hydrophilic characteristics of IL, allowing a closer contact with $\mathrm{H}_{2} \mathrm{O}_{2}$ associated with the high hydrophobic character of carbon, which allowed a closer contact with the oil phase [128]. Ma et al. (2019) reported similar results. Only $\mathrm{DBTO}_{2}$ was detected in the catalyst phase, and no sulfur compounds were observed in the oil phase [114].

Other reasons pointed out by the authors were the hydrophobic characteristics of GC in a polyoxometalate-based IL supported on GC, which allowed the catalyst to be better dispersed in the oil phase in the solvent-free ODS [128]. The protective environment arising from the CNT structure was also an essential feature, especially to avoid leaching of the active phase, thus increasing catalyst stability and reusability [129].

\subsubsection{Trends on Hybrid Materials Containing Carbonaceous Structures}

Carbon-based materials have proved to be an exciting platform either as supports for active phases or as components in hybrid materials, leading to highly active catalysts in ODS processes. Carbon materials can be used in a wide range of different approaches and systems. Most authors agree that the main contribution of the carbon-based structure is usually related to the high surface area displayed by those types of materials, which leads to a high degree of dispersion of the active phases. Others have also pointed out that the hydrophobic nature of the carbon structure increases the interaction of the hybrid materials with the organic phase and increases the contact between the oxidant and the target $S$ compound. A few authors also highlighted an increased electron transfer between the carbon structure and the active phase as the critical contribution of carbon structures. Specifically for photocatalytic systems, carbon-based materials have the advantage of reducing the recombination of electron-hole pairs, which dramatically boosts reaction rates. Carbon materials can act as catalysts of the process and adsorb the oxidized compounds, allowing solvent-free systems. Furthermore, carbon materials were able to avoid the leaching of active phases.

\subsection{Carbon Catalysts on Their Own}

Carbon-based materials have been reported as catalysts on their own for ODS reactions, and a summary with the main conditions and results are collected in Table 11. As observed, a series of carbon-based materials ( $\mathrm{AC}, \mathrm{GO}, \mathrm{rGO}$, and $\mathrm{CNT}$ ) have been assessed in the ODS of model compounds (mainly BT, DBT, or 4,6 DMDBT). Initial sulfur concentrations ranging between 400 and 2189 ppm were studied, considering mild operating conditions $\left(25-150^{\circ} \mathrm{C}\right)$, allowing to achieve removals higher than $95 \%$ from 30 min of reaction time. In general, carbon materials have displayed similar activity to those reported earlier considering hybrid or supported materials. The activity of the carbon material can be ascribed to the presence of defect sites on its surface, its developed surface area, or the presence of surface groups. Here, we propose the mechanism displayed in Figure 10 for the ODS of sulfur-containing compounds according to different proposals in the oxidation activity of carbon catalysts [130,131].

Gonzalez et al. (2012) compared a thermally treated AC (SX-1) and an AC treated with phosphoric acid (MW-99). MW-99 led to an increase in sulfur removal in the range 2.8-3.3 $\times$ compared to SX-1, depending on the sulfur compound. Those results were ascribed to a more developed surface area by MW-99, a lower content of basic sites and a higher concentration of acidic sites [132]. Haw et al. (2010) also found that the presence of acidic groups in AC, especially oxygenated groups, increased catalytic activity due to the electron-withdrawing characteristic of the acidic groups allied to the electron donor ability of $S$ compounds. This interaction between acidic groups and $S$ atoms increases the physisorption of S compounds in the AC structure [133]. 


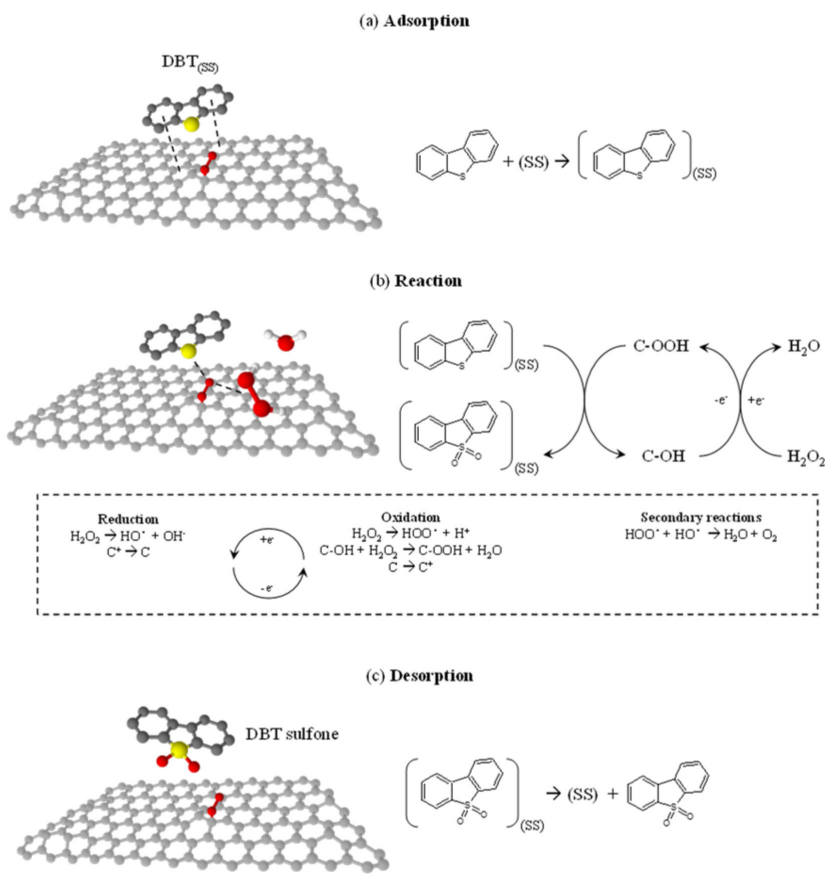

Figure 10. Oxidation mechanism of sulfur compounds (exemplified with DBT) on carbon catalysts (SS = Surface Site, draws prepared with Freeware Chemsketch; White, Red, Yellow, Gray atoms as hydrogen, oxygen, sulfur, and carbon, respectively).

He et al. (2019) [131] studied the influence of doping GO with nitrogen and oxygen for the aerobic ODS of various sulfur compounds. They compared two GO samples. The first was an N-doped GO subjected to annealing at $1000^{\circ} \mathrm{C}$, leading to PG-15. The other sample was obtained by subjecting PG-15 to thermal treatment in a muffle furnace at $450{ }^{\circ} \mathrm{C}$, leading to PG-450. PG-15 removed approximately $9.3 \%$ of DBT, which is mainly ascribed to an adsorption effect. On the other hand, PG- 450 could remove $98.5 \%$ of DBT in $5 \mathrm{~h}$ of reaction. The activity of PG-450 was ascribed to the oxygen groups (19.9\% as opposed to $3.6 \%$ for PG-15) and to an increase in the content of graphitic-like $\mathrm{N}$ structure in the material (47.8\% in PG-450 vs. $37.2 \%$ in PG-15). The main active sites for the activation of $\mathrm{O}_{2}$ are the oxygenated groups. However, since this activation requires an electron transfer process, the existence of electron-rich oxygenated groups should facilitate this electron transfer. In N, O-doped materials, the existence of electron-rich oxygen groups is ascribed to the enhanced electron delocalization that arises from the $\mathrm{N}$-doping. To demonstrate the synergistic effect of both $\mathrm{N}$ and $\mathrm{O}$ doping, a graphite material was calcined at $450{ }^{\circ} \mathrm{C}$ (Graphite-450) and tested in the ODS reactions. Graphite-450 is rich in oxygenated groups but poor in nitrogenated groups. In $5 \mathrm{~h}$, only a $40 \%$ removal of sulfur compounds was observed, thus reinforcing the synergy between $\mathrm{N}$ and $\mathrm{O}$ doping [131].

The presence of oxygenated groups was also found as crucial by Gu et al. (2019) [134] in the activity of oxidized CNTs (oCNTs). To identify which oxygenated groups were more relevant, they selectively removed different oxygenated groups (carboxylic, lactone, anhydride, phenolic, or carbonyls) through thermal treatment or selectively blocked some of them. When blocking or removing carbonyl groups, the activity of oCNT decreased drastically (from 100\% removal of DBT to $31 \%$ ), thus, pointing out the relevance of carbonyl groups. Gu et al. (2017) [135] have also found a positive correlation between carbonyl groups and catalytic activity. Other authors have reported that lactones and carboxylic groups also play an essential role [130].

On the other hand, some authors have reported that total oxygen-containing groups could not directly correlate to the catalytic activity in ODS experiments [136]. Zhang et al. (2014) have demonstrated that the change in the content of oxygen-containing groups affects the catalytic activity. However, there was no clear correlation between total content 
or specific groups in CNTs and desulfurization activity. Nonetheless, they did find a correlation between the increased graphitization degree of CNTs and increased catalytic activity. An increased graphitization is ascribed to a lower degree of defects. They attribute this phenomenon to a higher electron transfer due to higher electrical conductivity in highly graphitic CNTs [136]. In opposition to that, most authors seem to correlate the presence of defect sites to an increase in catalytic activity. Gu et al. (2019) observed an increase in defect sites after acid treatment $\left(\mathrm{D}^{*} / \mathrm{G}\right.$ value increased from 1.77 to $1.91 \mathrm{for} C N T s$ and oCNTs, respectively) which were correlated to the increased activity of oCNTs compared to CNTs (along with the oxygenated groups discussed above) [134]. In 2017, Gu et al. [135], by saturating defect sites in $\mathrm{rGO}$ through the formation of $\mathrm{C}-\mathrm{H}$ bonds, have observed a sharp decrease in DBT removal, thus pointing that defect sites also play a significant role in the activity of carbocatalysts. Zeng et al. (2017) [137] also identified zigzag edges and defects in GO as relevant active centers for the catalytic process.

In contrast, Timko et al. (2016) [138] reported that basal plane defects in AC are more relevant than edge defects. They presumed that basal plane defects are oxidized to generate carboxylic or percarboxylic acids on the surface of the material. Those oxygenated groups are then responsible for promoting ODS. The sulfur compounds are also expected to adsorb into the basal planes, increasing local concentration. However, adsorption alone is not sufficient. The surface oxidation allied to an increased local concentration of the sulfur compound in the carbon basal plane is the reason pointed out by the authors that distinguish the activity displayed by distinct ACs [138].

\section{Trends on Carbon-Based Catalysts}

In general, there are fewer reports related to the application of carbon-based materials as catalysts on their own in the ODS process as compared to their application in hybrid forms. However, carbon-based materials have proved to be adequate catalysts, and there is still room to study their application for desulfurization purposes.

Overall, the presence of acidic groups on the surface of carbon-based materials was related to higher desulfurization rates due to an acid-base interaction between carbon surface and sulfur molecules. Among the acidic surface groups, oxygen-containing groups are thought to be the active centers by most studies. However, there is still a controversy related to the influence of defect sites in catalytic activity.

Carbon-based materials have some unique advantages, especially their easy manipulation and introduction of surface groups. Nevertheless, there is a lack of reports related to applying doped carbon with heteroatoms other than oxygen and nitrogen. Thus, further investigating the influence of other dopants is an opportunity to apply carbon-based materials as catalysts on their own.

\subsection{Amphiphilic Carbons}

Amphiphilic carbons are materials that simultaneously display hydrophilic and hydrophobic characteristics. Thus, amphiphilic carbons can better interact with aqueous and organic phases. The contact angle of a water drop onto a material is widely used to describe amphiphilicity. Materials with a contact angle of $0^{\circ}$ are completely hydrophilic (high water-wettability), whereas materials with contact angles of $180^{\circ}$ are entirely hydrophobic. Amphiphilicity is an attractive characteristic when considering a biphasic reaction, as is the case of ODS, due to increased contact between an organic phase (fuels) and an extractant phase, which usually presents a more polar nature. Table 12 summarizes the reports related to the application of amphiphilic carbon-based materials for ODS reactions, main operating conditions, and results.

Abdi et al. (2017) [139] studied the removal of DBT from a simulated fuel in a biphasic system using $\mathrm{GO} / \mathrm{COOH}$ as a catalyst. They have attributed the high removal rates of sulfur to the amphiphilicity of $\mathrm{GO} / \mathrm{COOH}$, which allowed for better interaction with both hydrophilic $\mathrm{H}_{2} \mathrm{O}_{2}$ and hydrophobic sulfur compounds. Similarly, Liu et al. (2020) have observed that POM catalyst alone, due to its hydrophilicity, could not properly contact DBT 
(which is lipophilic). Thus, much better interaction between DBT and catalyst was observed by covering the POM catalyst with a hydrophobic carbon layer, significantly increasing the reaction rate [140]. In another approach, Yu et al. (2020) immobilized lipophilic $\mathrm{C}_{12} \mathrm{PW}$ on hydrophilic $\mathrm{g}-\mathrm{C}_{3} \mathrm{~N}_{4}$, thus increasing the utilization of hydrogen peroxide and the contact between DBT and active sites [141].

Li et al. (2019) found that $\mathrm{g}-\mathrm{C}_{3} \mathrm{~N}_{4}$ is not only responsible for improving the dispersion of the active phase (BMPO) but also for creating a heterojunction between support and $\mathrm{BMPO}$, which increases the utilization rate of electrons. Furthermore, the amphiphilic character of the catalyst solves the issue with the mass transfer between oily and aqueous phases [142].

Amphiphilic materials can also be applied in PIC-like approaches that rely on emulsion formation. The higher interfacial area between the apolar and polar phases in emulsion systems should increase the reaction rates. Mambrini et al. (2017) have studied ODS of DBT in emulsion systems (cyclohexane/aqueous $\mathrm{H}_{2} \mathrm{O}_{2}$ ) using metallic catalysts ( $\mathrm{Fe}$ and FeMo) modified with carbon to alter their amphiphilicity. Fe and FeMo alone could not remove any DBT; however, stable emulsions were formed when carbon coating was introduced, resulting in increased contact between organic and water phases, thus increasing reaction rates [143]. They proposed that the materials act in two ways: one, by increasing the interfacial area between phases due to the stabilization of an emulsion system, and two, through the activation of hydroxyl species in a Fenton-like system. The generated hydroxyls radicals were then able to oxidize DBT in the interface between the organic and the aqueous phase. The increased polarity and high interfacial area were also responsible for facilitating the extraction of $\mathrm{DBTO}_{2}$ [143]. Figure 11 shows the presumed mechanism for emulsified systems, adapted from elsewhere [144-146]. Other authors have also reported ODS emulsion systems that rely upon amphiphilic catalysts to increase catalytic activity [147].

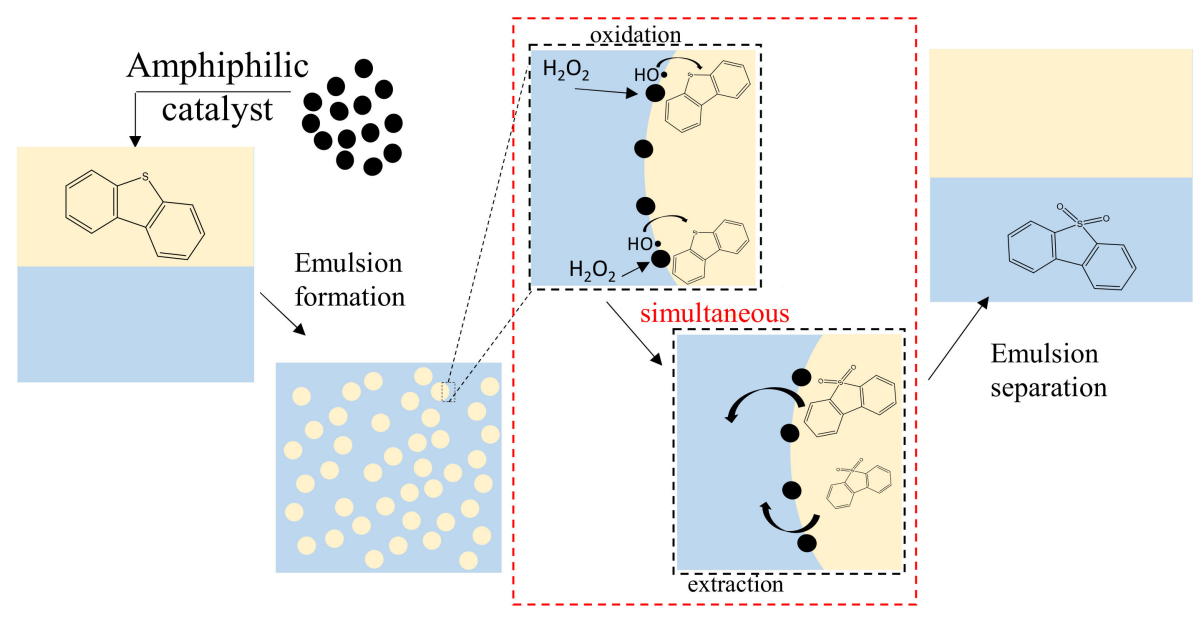

Figure 11. Presumed role of amphiphilic materials in biphasic oxidation under an emulsified system. Adapted from Oliveira et al. (2014) [145], Oliveira et al. (2015) [144], and Teixeira et al. (2013) [146].

Trends on the Application of Amphiphilic Materials

Amphiphilic materials have been applied in an extensive range of different ODS systems, including processes considering two-steps, biphasic systems, and PIC-like approaches. Regardless of the system, amphiphilic materials were attractive options due to their ability to interact with aqueous oxidant phases, lipophilic sulfur compounds, and organic phases simulating fuels. 
Table 4. ODS using mainly $\mathrm{H}_{22} \mathrm{O}$ with carbon hybrid materials in a two-step system.

\begin{tabular}{|c|c|c|c|c|c|}
\hline Fuel * & Catalyst & Extractant & Operational Conditions & Results & Ref. \\
\hline $\begin{array}{l}\text { DBT in EtOH } / \text { Hexane } \\
\left(C_{0}=500-1200 \mathrm{ppm}\right)\end{array}$ & $\begin{array}{l}\mathrm{H}_{5} \mathrm{PMo}_{10} \mathrm{~V}_{2} \mathrm{O}_{40} / \mathrm{Fe}_{3} \mathrm{O}_{4} / \mathrm{g}- \\
\mathrm{C}_{3} \mathrm{~N}_{4}\end{array}$ & $\mathrm{EtOH}$ & $\begin{aligned} \mathrm{V}_{\text {fuel }} & =2 \mathrm{~mL}, \mathrm{~m}_{\text {cat }}=0.03 \mathrm{~g} \\
\mathrm{n}_{\mathrm{H} 2 \mathrm{O} 2} & =10 \mathrm{mmol}, \mathrm{T}=80^{\circ} \mathrm{C}\end{aligned}$ & $\begin{array}{l}\text { Regardless of the initial concentration, complete desulfurization was } \\
\text { achieved in } 120-180 \text { min. For fuel with }[\mathrm{DBT}]_{0}=1000 \mathrm{ppm} \text {, the presence of } \\
\mathrm{N} \text { compounds slightly hindered the removal of DBT, reducing the overall } \\
\text { removal to } \sim 90-95 \% \text {. }\end{array}$ & [76] \\
\hline Real oil ([S $]_{0}=500$ and 1900 ppm) & $\begin{array}{l}\mathrm{H}_{5} \mathrm{PMo}_{10} \mathrm{~V}_{2} \mathrm{O}_{40} / \mathrm{Fe}_{3} \mathrm{O}_{4} / \mathrm{g}- \\
\mathrm{C}_{3} \mathrm{~N}_{4}\end{array}$ & $\mathrm{EtOH}$ & $\begin{array}{c}\mathrm{V}_{\text {fuel }}=5 \mathrm{~mL}+\text { mixed solvent } \\
\text { EtOH: Hexane }(1: 1, \mathrm{v} / \mathrm{v}) \\
\mathrm{m}_{\text {cat }}=0.03 \mathrm{~g}, \mathrm{n}_{\mathrm{H} 2 \mathrm{O} 2}=10 \mathrm{mmol} \\
\mathrm{T}=80^{\circ} \mathrm{C}\end{array}$ & $\begin{array}{l}\text { Twenty five and 30\% removal were possible for }\left[\mathrm{S}_{0}=500 \text { and } 1900 \mathrm{ppm} \text {, }\right. \\
\text { respectively. }\end{array}$ & [76] \\
\hline $\begin{array}{l}\mathrm{DBT}\left([\mathrm{S}]_{0}=1000-3000 \mathrm{ppm}\right), \mathrm{BT} \\
\left([\mathrm{S}]_{0}=100 \mathrm{ppm}\right) \text { or } 4,6-\mathrm{DMDBT} \\
\left([\mathrm{S}]_{0}=100 \mathrm{ppm}\right) \text { in n-Octane }\end{array}$ & 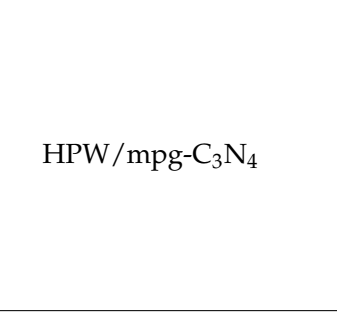 & $\mathrm{MeOH}$ & $\begin{array}{c}\mathrm{V}_{\text {fuel }}=10 \mathrm{~mL}, \mathrm{~m}_{\text {cat }}=10-120 \mathrm{mg} \\
\mathrm{H}_{2} \mathrm{O}_{2} / \mathrm{S}=2-12, \mathrm{~T}=30-70{ }^{\circ} \mathrm{C} \\
t=0.5-3 \mathrm{~h}\end{array}$ & $\begin{array}{l}\text { DBT: Increasing } \mathrm{S} \text { content reduced } \mathrm{S} \text { removal }\left(90,63 \text {, and } 58 \% \text { for }[\mathrm{S}]_{0} \text { of }\right. \\
1000,2000 \text {, and } 3000 \mathrm{ppm} \text {, respectively). In } 2.5 \mathrm{~h},>99 \% \text { removal was } \\
\text { possible. Increasing the } \mathrm{H}_{2} \mathrm{O}_{2} / \mathrm{S} \text { ratio from } 2 \text { to } 4 \text { results in a sharp increase } \\
\text { in } \mathrm{S} \text { removal, followed by a slight increase when further increasing to } 8 \\
(100 \% \text { removal). Maximum desulfurization is achieved at } 100 \mathrm{mg} \text { of } \\
\text { catalyst. Increasing temperature also increases } \mathrm{S} \text { Removal, especially at } \\
\text { lower reaction times. Fifteen recycle runs were possible, maintaining S } \\
\text { removals above } 98 \% \text {. Reactivity Followed the Order: DBT } \sim 4,6-\mathrm{DMDBT} \\
(100 \%)>\mathrm{BT}(80 \%) \text {. }\end{array}$ & [78] \\
\hline $\begin{array}{l}\mathrm{DBT}\left(C_{0}=500 \mathrm{ppm}\right), \mathrm{BT} \\
\left(C_{0}=250 \mathrm{ppm}\right), \text { and Th } \\
\left(C_{0}=250 \mathrm{ppm}\right) \text { in } \\
\text { EtOH } / \mathrm{n}-\text { Heptane }\end{array}$ & $\mathrm{HPW}-\mathrm{TiO}_{2} / \mathrm{g}-\mathrm{C}_{3} \mathrm{~N}_{4}$ & DMF & $\begin{aligned} \mathrm{V}_{\text {fuel }} & =5 \mathrm{~mL}, \mathrm{~m}_{\text {cat }}=0.03 \mathrm{~g} \\
\mathrm{n}_{\mathrm{H} 2 \mathrm{O} 2} & =12 \mathrm{mmol}, \mathrm{T}=80^{\circ} \mathrm{C}\end{aligned}$ & $\begin{array}{l}100 \% \text { removal of } \mathrm{S} \text { compounds in } 3 \mathrm{~h} \text { of reaction was observed. In the } \\
\text { presence of aromatic or } \mathrm{N} \text { compounds, } 100 \% \text { removal was also possible but } \\
\text { with longer reaction times }(4-6 \mathrm{~h}) \text {. }\end{array}$ & [84] \\
\hline Real Oil ([S $]_{0}=500$ or 1900 ppm) & $\mathrm{HPW}-\mathrm{TiO}_{2} / \mathrm{g}-\mathrm{C}_{3} \mathrm{~N}_{4}$ & $\begin{array}{l}\text { DMF: n-heptane }(1: 1 \\
\text { v/v) }\end{array}$ & $\begin{array}{c}\mathrm{V}_{\text {fuel }}=5 \mathrm{~mL}, \mathrm{~V}_{\mathrm{DMF}}=5 \mathrm{~mL} \\
\mathrm{~m}_{\text {cat }}=0.03 \mathrm{~g}, \mathrm{n}_{\mathrm{H} 2 \mathrm{O} 2}=12 \mathrm{mmol} \\
\mathrm{T}=80^{\circ} \mathrm{C}, t=200 \mathrm{~min}\end{array}$ & $\begin{array}{l}\text { Thirty and 35\% decrease in } S \text { content was observed ([S }]_{0} \text { of } 500 \text { and } \\
1900 \mathrm{ppm} \text {, respectively). }\end{array}$ & [84] \\
\hline Naphtha $\left([\mathrm{S}]_{0}=870 \mathrm{ppm}\right)$ & $\mathrm{Pd} / \mathrm{CNTs}$ & $\mathrm{ACN}$ & $\begin{array}{c}\mathrm{C}_{\text {cat }}=0-8.5 \mathrm{~g} \mathrm{~mL}^{-1}, \text { Volume } \\
\text { Ratio Fuel } / \mathrm{H}_{2} \mathrm{O}_{2}=10, \mathrm{~T}=25^{\circ} \mathrm{C} \\
t=30 \mathrm{~min}\end{array}$ & $\begin{array}{l}\text { Increasing the catalyst dosage from } 2.5 \text { to } 8.5 \mathrm{~g} \mathrm{~mL}^{-1} \text { resulted in a sharp } \\
\text { increase in S removal ( } 25 \text { to } 90 \% \text {, respectively). }\end{array}$ & [77] \\
\hline Naphtha $\left(C_{0}=\mathrm{NM}\right)$ & $\mathrm{MnO}_{x} / \mathrm{CNT}$ & $\mathrm{ACN}$ & $\begin{array}{c}\mathrm{C}_{\mathrm{cat}}=5 \mathrm{mg} \mathrm{mL}^{-1}, \mathrm{~V}_{\mathrm{H} 2 \mathrm{O} 2}=\mathrm{NM} \\
\mathrm{T}=25-30^{\circ} \mathrm{C}, t=30 \mathrm{~min}\end{array}$ & $\begin{array}{l}\text { After } 30 \mathrm{~min} \text {, comparing EDS and ODS process, desulfurization of } 9 \text { and } \\
83 \% \text { were achieved, respectively. Under optimum conditions, } 92 \% \\
\text { desulfurization was observed, maintained for } 4 \text { cycles. }\end{array}$ & [79] \\
\hline Gas Oil $\left([\mathrm{S}]_{0}=9400 \mathrm{ppm}\right)$ & $\mathrm{Fe}_{2} \mathrm{O}_{3}-\mathrm{GO}$ & $\mathrm{ACN}$ & $\begin{array}{l}\mathrm{V}_{\text {fuel }}=100 \mathrm{~mL}, \mathrm{~m}_{\text {cat }}=0.5-2.5 \mathrm{~g} \\
\mathrm{~V}_{\mathrm{H} 2 \mathrm{O} 2}=10 \mathrm{~mL}, 5 \mathrm{~mL} \text { of acetic } \\
\text { acid, } \mathrm{T}=40-60^{\circ} \mathrm{C}, t=160-240 \\
\text { min, } 2 \mathrm{~g} \text { of } \mathrm{Na}_{2} \mathrm{CO}_{3} \text { in } 20 \mathrm{~mL} \text { of } \\
\text { Water to Stop the Reaction. }\end{array}$ & $\begin{array}{l}\text { A DoE was used to determine the importance of some parameters, which } \\
\text { were found to be: time }>\text { temperature }>\text { catalyst dosage. The optimum } \\
\text { desulfurization }(92 \%) \text { was predicted at } 225 \text { min of reaction, } 2.5 \mathrm{~g} \text { of catalyst, } \\
\text { and } 60^{\circ} \mathrm{C} \text {. }\end{array}$ & [81] \\
\hline
\end{tabular}


Table 4. Cont.

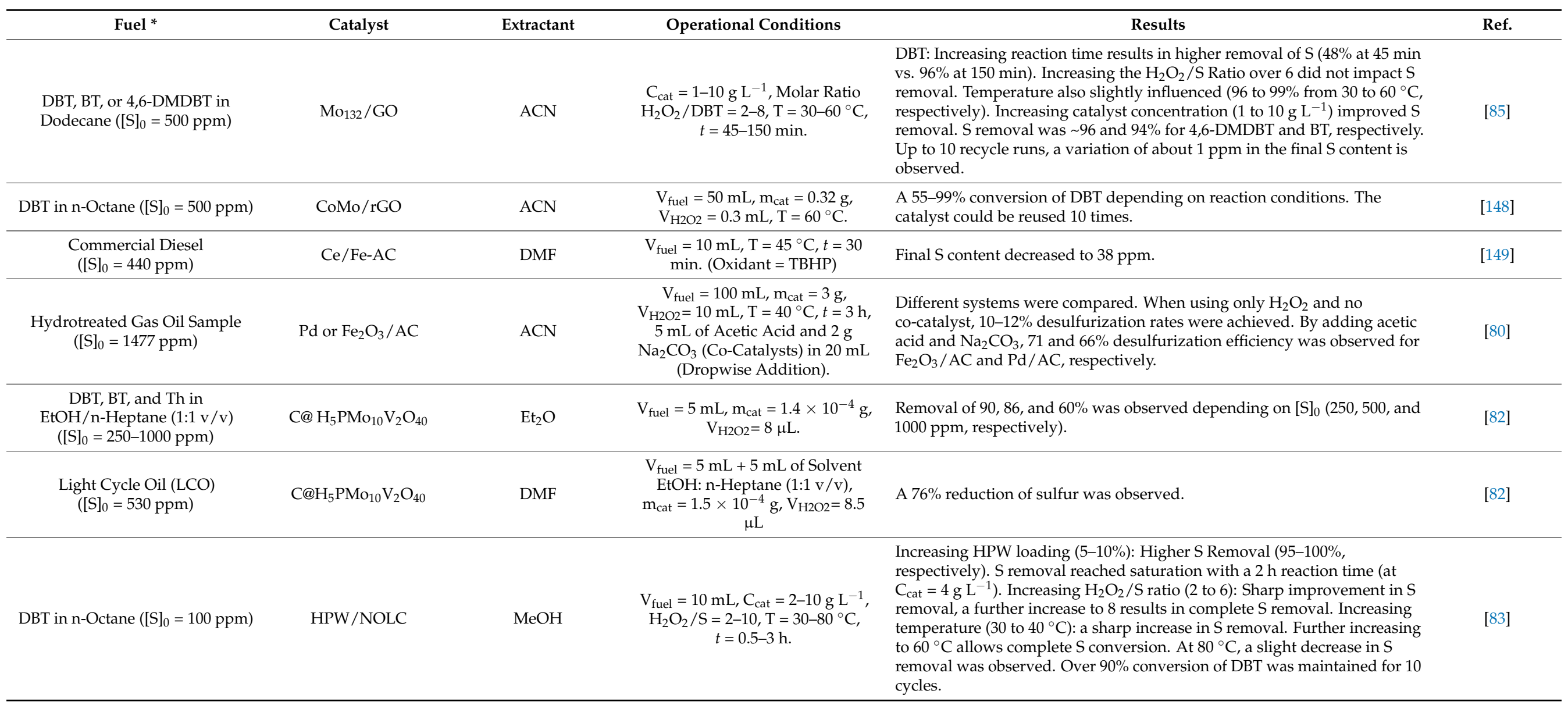

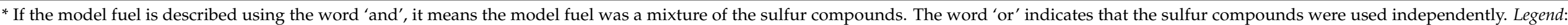

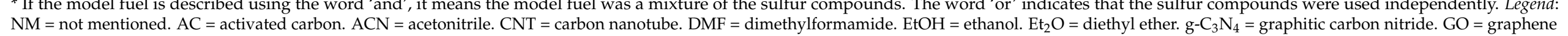
oxide. $\mathrm{HPW}=$ phosphotungstic acid $\left(\mathrm{H}_{3} \mathrm{PW}_{12} \mathrm{O}_{40}\right)$. MeOH = methanol. mpg- $\mathrm{C}_{3} \mathrm{~N}_{4}=$ mesoporous graphitic carbon nitride. NOLC = N-doped onion-like carbon . 
Table 5. ODS using $\mathrm{H}_{2} \mathrm{O}_{2}$ as oxidant with hybrid materials based in carbon nanotubes (CNTs), graphene oxide (GO), and reduced GO (rGO) in an L-L biphasic media.

\begin{tabular}{|c|c|c|c|c|c|}
\hline Fuel & Catalyst & Extractant & Operational Conditions & Main Results & Ref \\
\hline $\begin{array}{c}\text { DBT, BT or 4,6-DMDBT in n-Octane }\left([S]_{0}=800\right. \\
\left.\mu \mathrm{g} \mathrm{g} \mathrm{g}^{-1}\right)\end{array}$ & $\mathrm{WO}_{3} / \mathrm{CNT}$ & $\mathrm{ACN}$ & $\begin{array}{l}\mathrm{V}_{\text {fuel }}=5 \mathrm{~mL}, \mathrm{~V}_{\mathrm{ACN}}=1 \mathrm{~mL}, \mathrm{~m}_{\text {cat }}=0.03 \\
\mathrm{~g}, \mathrm{H}_{2} \mathrm{O}_{2} / \mathrm{S}=5, \mathrm{~T}=50^{\circ} \mathrm{C}, t=60 \mathrm{~min}\end{array}$ & $\begin{array}{l}\text { Removals of } \sim 78,90 \text {, and } 85 \% \text { were observed for BT, DBT, and 4,6-DMDBT, } \\
\text { respectively. dbt conversion was maintained for } 4 \text { cycles, in the 5th run decreasing to } \\
80 \% \text {. }\end{array}$ & [86] \\
\hline $\begin{array}{l}\text { DBT, 4,6-DMDBT, 2-MBT, 3-MBT, 3-MTh in } \\
\text { n-Octane ([S }]_{0}=2.8 \mathrm{mg} \mathrm{mL}^{-1} \text { ) }\end{array}$ & $\mathrm{CNT} / \mathrm{PVP} / \mathrm{MTO}$ & $\mathrm{ACN}$ & $\begin{array}{c}\mathrm{V}_{\text {fuel }}=2 \mathrm{~mL}, \text { Molar Ratio } \\
\text { Fuel } / \mathrm{ACN}=3: 1, \mathrm{n}_{\text {cat }}=0.1 \mathrm{mmol}, 4 \\
\text { Equivalents of } \mathrm{H}_{2} \mathrm{O}_{2}, \mathrm{~T}=60^{\circ} \mathrm{C} \\
\qquad t=24 \mathrm{~h} .\end{array}$ & $\begin{array}{l}\text { The order of reactivity was DBT }>4,6-\mathrm{DMDBT}>2-\mathrm{MBT} \sim 3-\mathrm{MBT}>3-\mathrm{MTh} \text {. Conversion } \\
\text { of all sulfur compounds was higher than } 99 \% \text {. After the } 6 \text { th recycle run, conversion } \\
\text { dropped to around } 40-78 \% \text { (depending on the compound) and stabilized around } \\
40-70 \% \text { up to the } 10 \text { th run. On the other hand, yield towards the respective sulfones } \\
\text { varied between } 38-99 \% \text { depending on the S compound. }\end{array}$ & {$[109$} \\
\hline DBT in n-Octane $\left(C_{0}=100-500 \mathrm{ppm}\right)$ & $\begin{array}{l}\mathrm{NH}_{2} / \mathrm{COOH}_{-} \mathrm{CNT} \\
/ \mathrm{MoO}_{3}\end{array}$ & $\mathrm{ACN}$ & $\begin{array}{c}\mathrm{V}_{\text {fuel }}=4 \mathrm{~mL}, \mathrm{~V}_{\mathrm{ACN}}=2 \mathrm{~mL} \\
\mathrm{~m}_{\text {cat }}=2.5-7.5 \mathrm{mg}, \mathrm{H}_{2} \mathrm{O}_{2} / \mathrm{S}=0.5-2 \\
\mathrm{~T}=25-60^{\circ} \mathrm{C}\end{array}$ & $\begin{array}{l}\text { With no extraction solvent, removal rates were low. The best desulfurization was } \\
\text { observed at } 60{ }^{\circ} \mathrm{C}, 7.5 \mathrm{mg} \text { of Catalyst, } \mathrm{H}_{2} \mathrm{O}_{2} / \mathrm{S} \text { ratio of } 2 \text {, Resulting in } 99 \% \\
\text { desulfurization. Increasing sulfur concentration slightly decreased conversion to } \\
98 \% \text {. }\end{array}$ & {$[110$} \\
\hline $\begin{array}{l}\text { DBT }\left([S]_{0}=100-600 \mathrm{ppm}\right), \mathrm{BT}\left([\mathrm{S}]_{0}=300 \mathrm{ppm}\right) \\
\text { or } 4,6-\mathrm{DMDBT}\left([\mathrm{S}]_{0}=300 \mathrm{ppm}\right) \text { in n-Octane }\end{array}$ & $\mathrm{WO}_{3} / \mathrm{MoO}_{3}-\mathrm{CNT}$ & $\mathrm{ACN}$ & $\begin{array}{c}\mathrm{V}_{\text {fuel }}=5 \mathrm{~mL}, \mathrm{~V}_{\mathrm{ACN}}=1 \mathrm{~mL} \\
\mathrm{n}_{\text {cat }}=0.1-0.3 \mathrm{mmol}, \mathrm{V}_{\mathrm{H} 2 \mathrm{O} 2}=0.5-1.5 \\
\mathrm{~mL}, \mathrm{~T}=25-60^{\circ} \mathrm{C}\end{array}$ & $\begin{array}{l}\text { Ninety nine percent conversion of DBT for }[\mathrm{S}]_{0}=100 \text { or } 300 \mathrm{ppm} \text {, which drops to } \\
95 \% \text { when }[\mathrm{S}]_{0}=600 \mathrm{ppm} \text {. The maximum conversion of BT is } 99 \% \text {, whereas } \\
4,6-\mathrm{DMDBT} \text { is } 82 \% \text {. Conversion depends on the initial concentration of precursors. }\end{array}$ & [111 \\
\hline DBT in n-Hexane $\left([S]_{0}=521 \mathrm{ppm}\right)$ & $\mathrm{W} / \mathrm{CNT}$ & $\mathrm{ACN}$ & $\begin{array}{c}\mathrm{V}_{\text {fuel }}=20 \mathrm{~mL}, \mathrm{~V}_{\mathrm{ACN}}=10 \mathrm{~mL}, \mathrm{C}_{\mathrm{cat}}=5 \\
\mathrm{~g} \mathrm{~L}^{-1}, \mathrm{H}_{2} \mathrm{O}_{2} / \mathrm{S}=17, \mathrm{~T}=10-50^{\circ} \mathrm{C} \\
t=90 \mathrm{~min}\end{array}$ & $\begin{array}{l}\text { At room temperature, a conversion higher than } 95 \% \text { was obtained. After the } 4 \text { th } \\
\text { recycle run, conversion dropped to } 25 \% \text { due to poisoning of active sites. }\end{array}$ & {$[103$} \\
\hline DBT in n-Octane $\left([S]_{0}=100-1100 \mathrm{ppm}\right)$ & $\begin{array}{l}\mathrm{Cs}_{2.5} \mathrm{H}_{0.5} \mathrm{PW}_{12} \mathrm{O}_{40} / \mathrm{CNT} \\
\mathrm{Cs}_{2.5} \mathrm{H}_{0.5} \mathrm{PW}_{12} \mathrm{O}_{40} / \mathrm{AC}\end{array}$ & $\mathrm{ACN}$ & $\begin{array}{c}\mathrm{V}_{\text {fuel }}=60 \mathrm{~mL}, \mathrm{~V}_{\mathrm{ACN}}=60 \mathrm{~mL} \\
\mathrm{~m}_{\text {cat }}=1 \mathrm{wt} . \% \text { (in Relation to Fuel), } \\
\mathrm{H}_{2} \mathrm{O}_{2} / \mathrm{S}=20, \mathrm{~T}=60^{\circ} \mathrm{C}, t=160 \mathrm{~min}\end{array}$ & $\begin{array}{l}\text { Using CNT as support increased sulfur removal from } 90 \text { to } 100 \% \text {, Compared to AC } \\
\text { support. A 100\% conversion of dbt was obtained and } 100 \% \text { yield towards the } \\
\text { sulfones. Three cycles were run with only a slight decline in conversion. }\end{array}$ & {$[101$} \\
\hline $\begin{array}{l}\text { Th, BT, DBT, 4-MBT, or 4,6-DMDBT in n-Octane } \\
\qquad\left(C_{0}=2000 \mathrm{ppm}\right)\end{array}$ & $\begin{array}{l}{[\text { Vim]POM/GO }} \\
{[\mathrm{DVim}] \mathrm{POM} / \mathrm{GO}} \\
\mathrm{P}[\mathrm{Vim}] \mathrm{POM} / \mathrm{GO}\end{array}$ & DMF & $\begin{array}{l}\mathrm{V}_{\text {fuel }}=10 \mathrm{~mL}, \mathrm{~V}_{\mathrm{DMF}}=10 \mathrm{~mL} \\
\mathrm{~m}_{\text {cat }}=0.1 \mathrm{~g}, \mathrm{~V}_{\mathrm{H} 2 \mathrm{O} 2}=0.56 \mathrm{~mL} \\
\left(\mathrm{H}_{2} \mathrm{O}_{2} / \mathrm{S}=9\right), \mathrm{T}=50^{\circ} \mathrm{C}\end{array}$ & $\begin{array}{l}\text { Desulfurization efficiency of the IL were: P[Vim]POM }(100 \% \text {, for } 5 \\
\text { runs) > [Vim]POM }(93 \%)>\text { [DVim]POM }(86 \%) \text { for DBT. Removals for the remaining } \\
\text { S compounds: 4,6-DMDBT and 4-MBT were } 100 \% \text { and BT and Th were } 96 \% \text { and } \\
92 \% \text {, respectively. }\end{array}$ & [87] \\
\hline $\begin{array}{l}\text { DBT, BT, or 4,6-DMDBT }\left([S]_{0}=500 \mathrm{ppm}, \text { each) in }\right. \\
\text { n-Hexane and a Mixed Fuel of DBT, BT, and } \\
\text { 4,6-DMDBT }\left([\mathrm{S}]_{0}=500 \mathrm{ppm} \text {, Total) in n-Hexane }\right.\end{array}$ & $\mathrm{HPW} / \mathrm{GO}$ & $\mathrm{ACN}$ & $\begin{array}{c}\mathrm{V}_{\text {fuel }} / \mathrm{V}_{\mathrm{ACN}}=1, \mathrm{C}_{\text {cat }}=5 \mathrm{~g} \mathrm{~L}^{-1} \\
\mathrm{H}_{2} \mathrm{O}_{2} / \mathrm{S}=6, \mathrm{~T}=60^{\circ} \mathrm{C}\end{array}$ & $\begin{array}{l}\text { DBT and 4,6-DMDBT removal achieved } 100 \% \text {, whereas BT was only } 70 \% \text {. In mixed } \\
\text { fuel, overall } S \text { removal was } 99 \% \text {. Removal of S higher than } 90 \% \text { for } 8 \text { cycles. }\end{array}$ & {$[150$} \\
\hline $\begin{array}{l}\text { DBT, BT, or 4,6-DMDBT in n-Hexane } \\
\quad\left([\mathrm{S}]_{0}=500 \mathrm{mg} \mathrm{g}^{-1}\right)\end{array}$ & $\mathrm{H}_{3} \mathrm{PMo}_{12} \mathrm{O}_{40}-\mathrm{GO}$ & $\mathrm{ACN}$ & $\begin{array}{c}\mathrm{V}_{\text {fuel }}=5 \mathrm{~mL}, \mathrm{~V}_{\text {ACN }} / \mathrm{V}_{\text {fuel }}=0.1-1 \\
\mathrm{C}_{\text {cat }}=1-3 \mathrm{~g} \mathrm{~L}^{-1}, \mathrm{H}_{2} \mathrm{O}_{2} / \mathrm{S}=2-8 \\
\mathrm{~T}=25-60^{\circ} \mathrm{C}\end{array}$ & $\begin{array}{l}\text { BT removal varied from } 55-70 \% \text {, DBT } 70-100 \% \text {, and } 4,6 \text {-DMDBT } 70-100 \% \text {, } \\
\text { depending on operational conditions. Optimal operating conditions were } 50{ }^{\circ} \mathrm{C} \text {, } \\
\mathrm{V}_{\text {extractant }} / \mathrm{V}_{\text {fuel }} \text { of } 0.3 \text { and } \mathrm{H}_{2} \mathrm{O}_{2} / \mathrm{S} \text { of } 6 \text {. }\end{array}$ & {$[151$} \\
\hline
\end{tabular}

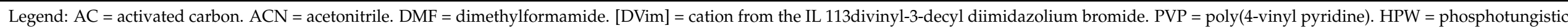
acid $\left(\mathrm{H}_{3} \mathrm{PW}_{12} \mathrm{O}_{40}\right) . \mathrm{MeOH}=$ methanol. $\mathrm{MTO}=$ Methyltrioxorhenium. $\mathrm{POM}=$ polyoxometalate $\left(\mathrm{H}_{8} \mathrm{P}_{2} \mathrm{Mo}_{16} \mathrm{~V}_{2} \mathrm{O}_{62} \cdot 14 \mathrm{H}_{2} \mathrm{O}\right)$. [Vim] = cation from the IL 1-vinyl-3-amylimidazolium bromide. 
Table 6. ODS using $\mathrm{H}_{2} \mathrm{O}_{2}$ as oxidant with hybrid materials based on activated carbon (AC) in an L-L biphasic media.

\begin{tabular}{|c|c|c|c|c|c|}
\hline Fuel & Catalyst & Extractant & Operational Conditions & Main Results & Ref. \\
\hline $\begin{array}{l}\text { Th in a Mixed Solvent (Xylene, } \\
\text { Octadiene, Cyclohexene, } \\
\text { n-Hexane) }\left([\mathrm{S}]_{0}=489 \mathrm{ppm}\right)\end{array}$ & $\mathrm{HPW} / \mathrm{AC}$ & $\mathrm{H}_{2} \mathrm{O}_{2}$ Aqueous Solution & $\begin{array}{c}\mathrm{V}_{\text {fuel }}=20 \mathrm{~mL}, \mathrm{~m}_{\mathrm{cat}}=0.5 \mathrm{~g}, \mathrm{~V}_{\mathrm{H} 2 \mathrm{O} 2}=4 \\
\mathrm{~mL}, 0.05 \mathrm{~g} \text { of CTAB, Emulsified } \\
\text { System. }\end{array}$ & $\begin{array}{l}\text { In simulated fuel using only n-Hexane, desulfurization of } 90 \% \text { was obtained at } \\
90^{\circ} \mathrm{C} \text { and } 120 \mathrm{~min} \text {. For mixed solvents, upon adding } 1-15 \mathrm{wt} . \% \text { of xylene, Th } \\
\text { removal was } 75.9-59.2 \% \text {. Similarly, for cyclohexane addition }(1-15 \mathrm{wt} . \%) \text {, a Th } \\
\text { Removal of } 62-7 \% \text { was observed. Adding Octadiene }(1-15 \mathrm{wt} . \%) \text { decreased Th } \\
\text { conversion to } 52.6-31.4 \% \text {. Octadiene and Cyclohexane have a strong negative } \\
\text { effect, whereas Xylene has a milder negative effect. }\end{array}$ & [91] \\
\hline $\begin{array}{l}\text { Commercial Gasoline } \\
\left([\mathrm{S}]_{0}=280 \mathrm{ppm}\right)\end{array}$ & $\mathrm{HPW} / \mathrm{AC}$ & $\mathrm{H}_{2} \mathrm{O}_{2}$ Aqueous Solution & $\begin{array}{c}\mathrm{V}_{\text {fuel }}=20 \mathrm{~mL}, \mathrm{~m}_{\text {cat }}=0.5 \mathrm{~g}, \mathrm{~V}_{\mathrm{H} 2 \mathrm{O} 2}=4 \\
\mathrm{~mL}, 0.05 \mathrm{~g} \text { of CTAB, Emulsified } \\
\text { System. }\end{array}$ & $\begin{array}{l}\text { Sulfur removal depended greatly on the compound. Th desulfurization was only } \\
32 \% \text {. }\end{array}$ & [91] \\
\hline $\begin{array}{l}\text { DBT in n-Octane } \\
\left(C_{0}=2000 \mathrm{ppm}\right)\end{array}$ & HPW/AC & $\mathrm{H}_{2} \mathrm{O}_{2}$ Aqueous Solution & $\begin{array}{c}\mathrm{V}_{\text {fuel }}=40 \mathrm{~mL}, \text { Mass Ratio Cat: } \\
\text { Fuel }=1.25: 100, \text { vol. ratio } \mathrm{H}_{2} \mathrm{O}_{2}: \\
\text { Fuel }=1: 10, \mathrm{~T}=60^{\circ} \mathrm{C}, t=12 \mathrm{~min}, 70 \\
\text { W. }\end{array}$ & $\begin{array}{l}\text { Decreasing particle size of the AC support improves desulfurization due to an } \\
\text { increase in surface area. Increasing HPW loading up to } 10 \% \text { increases } \\
\text { desulfurization; however, further increasing reduces AC surface area and } \\
\text { interferes with the ac structure effect in the ultrasound-assisted process. } \\
\text { Ultrasound power over } 70 \mathrm{~W} \text { did not improve desulfurization. DBT removal was } \\
100 \% \text {. }\end{array}$ & [108] \\
\hline Th in n-Octane $\left(C_{0}=656 \mathrm{ppm}\right)$ & $\mathrm{Pd} / \mathrm{AC}$ & $\begin{array}{l}\text { Aqueous Solution Containing } \\
2 \mathrm{~g} \mathrm{NaOH}, 5 \mathrm{~g} \text { Water, and } 2.5 \mathrm{~g} \\
\text { 2-Propanol }\end{array}$ & $\begin{array}{c}\mathrm{m}_{\text {fuel }}=14 \mathrm{~g}, \mathrm{~m}_{\text {extractant }}=9.5 \mathrm{~g} \\
\mathrm{~m}_{\text {cat }}=0.05 \mathrm{~g}, \mathrm{~m}_{\text {oxidant }}=2.5 \mathrm{~g} \\
\text { (2-Propanol) }, \mathrm{T}=50-70^{\circ} \mathrm{C} \text {, In-Situ } \\
\text { Generation of } \mathrm{H}_{2} \mathrm{O}_{2} \text { from 2-Propanol. }\end{array}$ & $\begin{array}{l}\text { After } 20 \mathrm{~min} \text { at } 70{ }^{\circ} \mathrm{C} \text {, a model fuel with sulfur content lower than } 1 \mathrm{ppm} \text { is } \\
\text { obtained. Obtaining fuels with ultra-low sulfur at lower temperatures is possible; } \\
\text { however, more time is required. }>99 \% \text { conversion was maintained for } 5 \text { cycles. }\end{array}$ & [104] \\
\hline $\begin{array}{l}\text { DBT in n-Octane } \\
\left(C_{0}=2000 \mathrm{ppm}\right)\end{array}$ & $\mathrm{HPW} / \mathrm{AC}$ & $\mathrm{H}_{2} \mathrm{O}_{2}$ Aqueous Solution & $\begin{array}{c}\mathrm{V}_{\text {fuel }}=40 \mathrm{~mL}, \mathrm{C}_{\text {cat }}=1.25 \text { wt. } \% \\
\text { Volume } \text { Ratio }_{2} \mathrm{O}_{2}: \\
\text { Fuel }=1: 400-1: 10\left(\mathrm{H}_{2} \mathrm{O}_{2} / \mathrm{S}=3-123\right) \\
\mathrm{T}=40-70^{\circ} \mathrm{C}, t=3-30 \text { min, }, 70-100 \mathrm{~W} \\
\text { Ultrasound, Emulsion Formation. }\end{array}$ & 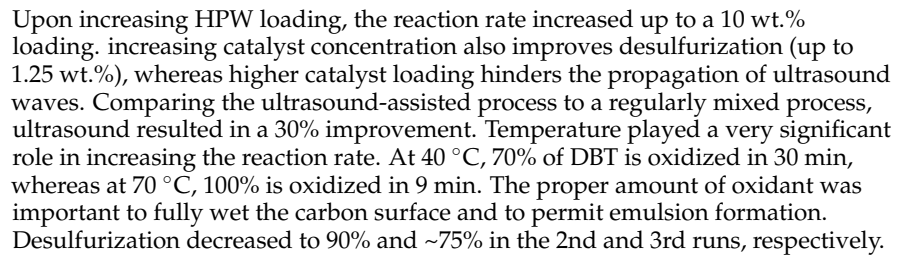 & [107] \\
\hline $\begin{array}{l}\text { DBT in n-Octane } \\
\left([\mathrm{S}]_{0}=300 \mathrm{ppm}\right)\end{array}$ & $\mathrm{HPW} / \mathrm{AC}$ & $\mathrm{H}_{2} \mathrm{O}_{2}$ Aqueous Solution & $\begin{array}{c}\mathrm{m}_{\text {fuel }}=25 \mathrm{~g}, \mathrm{~m}_{\text {cat }}=0.1 \mathrm{~g}, \mathrm{H}_{2} \mathrm{O}_{2} / \mathrm{S}=4 \\
\mathrm{~T}=80^{\circ} \mathrm{C}, t=40 \mathrm{~min}\end{array}$ & $\begin{array}{l}\text { HPW Loading of } 10 \% \text { was found as optimal. Increasing the } \mathrm{H}_{2} \mathrm{O}_{2} / \mathrm{S} \text { Ratio and } \\
\text { temperature improves desulfurization. At lower temperatures, a higher amount } \\
\text { of oxidant is necessary to achieve full desulfurization. A total of } 100 \% \text { removal of } \\
\text { DBT obtained. }\end{array}$ & {$[105]$} \\
\hline $\begin{array}{l}\text { DBT in n-Octane } \\
\left([\mathrm{S}]_{0}=500-1000 \mathrm{ppm}\right)\end{array}$ & $\mathrm{Mo}_{132} / \mathrm{AC}$ & ACN & $\begin{array}{c}\mathrm{V}_{\text {fuel }}=5 \mathrm{~mL}, \mathrm{~V}_{\mathrm{ACN}}=5 \mathrm{~mL} \\
\mathrm{~m}_{\text {cat }}=0-0.005 \mathrm{~g}, \mathrm{H}_{2} \mathrm{O}_{2} / \mathrm{S}=2-30 \\
\mathrm{~T}=25-45^{\circ} \mathrm{C}\end{array}$ & $\begin{array}{l}\text { With no catalyst, } 46 \% \text { removal of DBT was observed in } 120 \mathrm{~min} \text {. Using } 0.0025 \mathrm{~g} \text { of } \\
\text { catalyst Led to } 100 \% \text { removal in } 30 \mathrm{~min} \text {. Temperature shortened reaction time } \\
\text { required to achieve deep desulfurization to } 10 \mathrm{~min} \text { at } 45^{\circ} \mathrm{C} \text {. Increasing the } \\
\mathrm{H}_{2} \mathrm{O}_{2} / \mathrm{S} \text { ratio improved desulfurization up to } 10 \text {, further increase negatively } \\
\text { affected s removal. A total of } 100 \% \text { removal was achieved for }[\mathrm{S}]_{0} \text { of } 500,700 \text {, and } \\
1000 \text { in } 30,60 \text {, and } 120 \text { min. }\end{array}$ & [106] \\
\hline
\end{tabular}

Legend: $\mathrm{ACN}=$ acetonitrile. $\mathrm{HPW}=$ phosphotungistic acid $\left(\mathrm{H}_{3} \mathrm{PW}_{12} \mathrm{O}_{40}\right)$. 
Table 7. ODS using mainly $\mathrm{H}_{2} \mathrm{O}_{2}$ with hybrid materials based on other carbon forms in an L-L biphasic media.

\begin{tabular}{|c|c|c|c|c|c|}
\hline Fuel & Catalyst & Extractant & Operational Conditions & Main Results & Ref. \\
\hline $\begin{array}{l}\text { Th, BT, DBT, or 4,6-DMDBT } \\
\text { in n-Octane } \\
\left([\mathrm{S}]_{0}=1000 \mathrm{ppm}\right)\end{array}$ & $\mathrm{TiO}_{2}-\mathrm{C}$ & $\mathrm{ACN}$ & $\begin{array}{c}\mathrm{V}_{\text {fuel }}=10 \mathrm{~mL}, \mathrm{~V}_{\mathrm{ACN}}=5 \mathrm{~mL} \\
\mathrm{~m}_{\text {cat }}=20 \mathrm{mg}, \mathrm{V}_{\mathrm{H} 2 \mathrm{O} 2}=0.114 \mathrm{~mL} \\
\left(\mathrm{H}_{2} \mathrm{O}_{2} / \mathrm{S}=15\right), \mathrm{T}=80^{\circ} \mathrm{C}\end{array}$ & $\begin{array}{l}\text { The reactivity order is DBT }(100 \%)>\text { BT }(60 \%)>\text { Th }(50 \%)>4,6 \text {-DMDBT } \\
(38 \%) \text {. For DBT model fuel, conversion }>95 \% \text { was maintained for } 5 \text { runs. }\end{array}$ & [92] \\
\hline $\begin{array}{l}\text { Th, BT or DBT in n-Octane } \\
\quad\left([S]_{0}=1000 \mathrm{ppm}\right)\end{array}$ & $\mathrm{W}_{2} \mathrm{~N} / \mathrm{C}$ & $\mathrm{ACN}$ & $\begin{aligned} \mathrm{V}_{\text {fuel }}= & 10 \mathrm{~mL}, \mathrm{~V}_{\mathrm{ACN}}=5 \mathrm{~mL} \\
\mathrm{~m}_{\text {cat }}= & 0.02 \mathrm{~g}, \mathrm{H}_{2} \mathrm{O}_{2} / \mathrm{S}=15 \\
& \mathrm{~T}=30-80^{\circ} \mathrm{C}\end{aligned}$ & $\begin{array}{l}\text { DBT conversion maintained over } 90 \% \text { for } 5 \text { cycles. Removals of Th and } \\
\text { BT were } 80 \text { and } 90 \% \text {, respectively. }\end{array}$ & [93] \\
\hline $\begin{array}{l}\text { DBT in Hexane } \\
\left(C_{0}=1000 \mathrm{ppm}\right)\end{array}$ & PET-Modified Red Mud & $\mathrm{ACN}$ & $\begin{array}{c}\mathrm{V}_{\text {fuel }}=10 \mathrm{~mL}, \mathrm{~V}_{\mathrm{ACN}}=2 \mathrm{~mL} \\
\mathrm{~m}_{\text {cat }}=5-20 \mathrm{mg}, \mathrm{V}_{\mathrm{H} 2 \mathrm{O} 2}=1 \mathrm{~mL} \\
\mathrm{~T}=25^{\circ} \mathrm{C}\end{array}$ & $\begin{array}{l}\text { Maximum removal of } 80 \% \text { is observed at a catalyst loading of } 10 \mathrm{mg} \text {. } \\
\text { Exceeding that value does not improve desulfurization. }\end{array}$ & [94] \\
\hline $\begin{array}{l}\text { BT, DBT or } 4,6-\mathrm{DMDBT} \text { in } \\
\text { Heptane }\left(C_{0}=0.5 \mathrm{mmol}\right)\end{array}$ & $\mathrm{H}_{3} \mathrm{PMo}_{12} \mathrm{O}_{40} / \mathrm{C}$ & $\mathrm{H}_{2} \mathrm{O}$ & $\begin{array}{c}\mathrm{V}_{\text {fuel }}=5 \mathrm{~mL}, \mathrm{~V}_{\text {extractant }}=5 \mathrm{~mL} \\
\mathrm{n}_{\text {cat }}=0.0041 \mathrm{mmol}, \mathrm{n}_{\mathrm{H} 22}=1.5 \\
\mathrm{mmol} \mathrm{H}_{2} \mathrm{O}_{2} / \mathrm{S}=3, \mathrm{~T}=60^{\circ} \mathrm{C}\end{array}$ & $\begin{array}{l}\text { A } 100 \% \text { conversion of DBT in } 30 \text { min for } 8 \text { Cycles. 4,6-DMDBT required } \\
60 \text { min to be degraded, whereas BT Required } 120 \text { min. Increasing } \\
\mathrm{H}_{2} \mathrm{O}_{2} / \mathrm{S} \text { over } 3 \text { impacted the efficiency of } \mathrm{H}_{2} \mathrm{O}_{2} \text { use. Increasing reaction } \\
\text { temperature over } 60^{\circ} \mathrm{C} \text { negatively affected the reaction. }\end{array}$ & {$[100]$} \\
\hline $\begin{array}{l}\text { Pyrolysis Oil of Waste Tires } \\
\quad\left([\mathrm{S}]_{0}=7139 \mathrm{ppm}\right)\end{array}$ & Biochar & $\begin{array}{l}\text { Aqueous } 10 \mathrm{wt} . \% \\
\mathrm{H}_{2} \mathrm{O}_{2} \text { Phase }\end{array}$ & $\begin{array}{c}\mathrm{m}_{\text {fuel }}=2 \mathrm{~g}, \mathrm{~V}_{\text {extractant }}=15 \mathrm{~mL} \\
\mathrm{~V}_{10 \mathrm{wt} . \% \mathrm{H} 2 \mathrm{O} 2}=15 \mathrm{~mL} \\
\mathrm{~T}=60-100{ }^{\circ} \mathrm{C}, t=2-6 \mathrm{~h}\end{array}$ & $\begin{array}{l}\text { Desulfurization ranged from } 33-64 \% \text { depending on catalyst } \\
\text { concentration and on the precursor of the biochar (coffee ground or } \\
\text { waste tire). }\end{array}$ & [152] \\
\hline $\begin{array}{l}\text { DBT, Th, BT, or 4,6-DMDBT } \\
\text { in n-Octane }\left(C_{0}=1000 \mathrm{ppm}\right)\end{array}$ & Co/N-doped C & $\mathrm{ACN}$ & $\begin{array}{c}\mathrm{V}_{\text {fuel }}=20 \mathrm{~mL}, \mathrm{~V}_{\mathrm{ACN}}=5 \mathrm{~mL} \\
\mathrm{~m}_{\text {cat }}=10 \mathrm{mg}, \mathrm{V}_{\mathrm{H} 2 \mathrm{O} 2}=0.2 \mathrm{~mL} \\
\mathrm{H}_{2} \mathrm{O}_{2} / \mathrm{S} \text { ratio }=15, \mathrm{~T}=70^{\circ} \mathrm{C} \\
\quad t=120 \text { min. }\end{array}$ & $\begin{array}{l}\sim 93 \% \text { removal of DBT for } 5 \text { cycles. Removals of BT, Th, and 4,6-DMDBT } \\
\text { were } 65,50 \text {, and } 50 \% \text {, respectively. }\end{array}$ & [112] \\
\hline $\begin{array}{l}\text { DBT, 4-MDBT or 4,6-DMDB } \\
\text { in Dodecane }\left([\mathrm{S}]_{0}=200 \mathrm{ppm}\right)\end{array}$ & HPW/3D-CS & $\begin{array}{l}\text { Adsorption on } \\
\text { 3D-CS }\end{array}$ & $\begin{array}{l}\mathrm{V}_{\text {fuel }}=5 \mathrm{~mL}, 1 \mathrm{~mL} \text { of acetic acid, } \\
\mathrm{m}_{\text {cat }}=0.2 \mathrm{~g}, \mathrm{H}_{2} \mathrm{O}_{2} / \mathrm{S}=8 \\
\mathrm{~T}=70^{\circ} \mathrm{C}, t=40 \mathrm{~min}\end{array}$ & $\begin{array}{l}\text { The optimal loading of HPW was found to be } 7 \mathrm{wt} . \% \text {. A total of } 100 \% \\
\text { removal of DBT maintained for } 3 \text { cycles, slight decrease on the } 4 \text { th and } \\
5 \text { th cycles (to } 93 \% \text { ). the desulfurization rate was very similar regardless } \\
\text { of the model sulfur compound. One hundred percent desulfurization } \\
\text { was achieved for all model oils in } 2.5 \mathrm{~h} \text {. }\end{array}$ & [97] \\
\hline $\begin{array}{l}\text { Th in n-Octane } \\
\left([\mathrm{S}]_{0}=1000 \mathrm{ppm}\right)\end{array}$ & $\begin{array}{c}{\left[\mathrm{C}_{\mathrm{n}} \mathrm{VP}\right] \mathrm{MoV} /} \\
\mathrm{CA}(\mathrm{n}=2,4,6,8, \text { or } 10)\end{array}$ & DMF & $\begin{array}{c}\mathrm{V}_{\text {fuel }}=40 \mathrm{~mL}, \mathrm{~V}_{\mathrm{DMF}}=10 \mathrm{~mL} \\
\mathrm{~m}_{\text {cat }}=0.04 \mathrm{~g}, \mathrm{O}_{2} \text { flow rate } 1 \mathrm{~L} \\
\min ^{-1}, \mathrm{~T}=\text { Room Temperature. }\end{array}$ & $\begin{array}{l}\text { Increasing the chain length of the catalyst }(n=2-6) \text { increases } \\
\text { desulfurization. For } n>6 \text {, the steric hindrance of the material increases, } \\
\text { and desulfurization is hindered. The maximum removal observed was } \\
99.6 \% \text {. }\end{array}$ & [89] \\
\hline
\end{tabular}

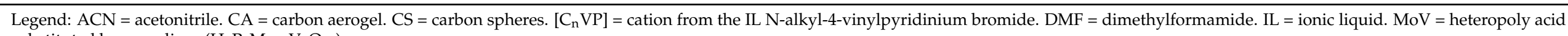
substituted by vanadium $\left(\mathrm{H}_{8} \mathrm{P}_{2} \mathrm{Mo}_{16} \mathrm{~V}_{2} \mathrm{O}_{62}\right)$. 
Table 8. ODS using $\mathrm{H}_{2} \mathrm{O}_{2}$ with hybrid materials based on graphitic carbon nitride $\left(\mathrm{g}-\mathrm{C}_{3} \mathrm{~N}_{4}\right)$ in an L-L biphasic media.

\begin{tabular}{|c|c|c|c|c|c|}
\hline Fuel & Catalyst & Extractant & Operational Conditions & Main Results & Ref. \\
\hline $\begin{array}{l}\text { BT, DBT, or } 4,6-\mathrm{DMDBT} \text { in } \\
\text { n-Octane }\left([\mathrm{S}]_{0}=320 \mathrm{ppm}\right)\end{array}$ & $\mathrm{MoO}_{3} / \mathrm{g}-\mathrm{C}_{3} \mathrm{~N}_{4}$ & $\mathrm{MeOH}$ & $\begin{array}{c}\mathrm{V}_{\text {fuel }}=15 \mathrm{~mL}, \mathrm{~V}_{\mathrm{MeOH}}=15 \\
\mathrm{~mL}, \mathrm{C}_{\mathrm{cat}}=0.013 \mathrm{mg} \mathrm{L}^{-1} \\
\mathrm{H}_{2} \mathrm{O}_{2} / \mathrm{S}=4, \mathrm{~T}=60^{\circ} \mathrm{C}\end{array}$ & $\begin{array}{l}\text { With the addition of specific scavengers for }{ }^{\bullet} \mathrm{O}_{2}{ }^{-}, \mathrm{h}^{+}, \mathrm{e}^{-} \text {and } \mathrm{HO} \mathrm{O}^{\bullet} \text {, } \\
\text { the authors have observed that } \mathrm{HO} \mathrm{C}^{\bullet} \text { was the most important } \\
\text { radical. desulfurization rates were: }>96 \% \text { removal for } 6 \text { cycles } \\
(\text { DBT), }>85 \% \text { for } 4,6 \text {-DMDBT and } 60 \% \text { for BT. }\end{array}$ & [95] \\
\hline $\begin{array}{l}\text { DBT, BT or Th in n-Octane } \\
\quad\left([\mathrm{S}]_{0}=500 \mu \mathrm{g} \mathrm{g}^{-1}\right)\end{array}$ & $\mathrm{WO}_{3} / \mathrm{g}-\mathrm{C}_{3} \mathrm{~N}_{4}$ & $\begin{array}{l}\text { IL: 1-Ethyl-3- } \\
\text { Methylimidazolium } \\
\text { Ethyl Sulfate }\end{array}$ & $\begin{array}{c}\mathrm{V}_{\text {fuel }}=5 \mathrm{~mL}, \mathrm{~V}_{\mathrm{IL}}=1 \mathrm{~mL} \\
\mathrm{~m}_{\mathrm{cat}}=0.02 \mathrm{~g}, \mathrm{~V}_{\mathrm{H} 2 \mathrm{O} 2}=0.2 \mathrm{~mL} \\
\mathrm{~T}=70^{\circ} \mathrm{C}, t=3 \mathrm{~h}\end{array}$ & $\begin{array}{l}\mathrm{WO}_{3} \text { supported over } \mathrm{g}^{-} \mathrm{C}_{3} \mathrm{~N}_{4} \text { has a higher desulfurization activity } \\
\text { than unsupported } \mathrm{WO}_{3} \text { or supported over alumina. The order of } \\
\text { reactivity was DBT }(96 \%)>\mathrm{BT}(73 \%)>\text { Th }(53 \%) \text {. The catalyst } \\
\text { could be reused } 5 \text { times with }>85 \% \text { removal of DBT. }\end{array}$ & [90] \\
\hline $\begin{array}{l}\text { DBT, BT or Th in n-Octane } \\
\quad\left([\mathrm{S}]_{0}=500 \mu \mathrm{g} \mathrm{g}^{-1}\right)\end{array}$ & $\mathrm{CoWO}_{4} / \mathrm{g}-\mathrm{C}_{3} \mathrm{~N}_{4}$ & IL: [EMIM] $\left[\mathrm{EtSO}_{4}\right]$ & $\begin{array}{c}\mathrm{V}_{\text {fuel }}=5 \mathrm{~mL}, \mathrm{~V}_{\mathrm{IL}}=1 \mathrm{~mL} \\
\mathrm{~m}_{\text {cat }}=0.03 \mathrm{~g}, \mathrm{~V}_{\mathrm{H} 2 \mathrm{O} 2}=0.4 \mathrm{~mL} \\
\mathrm{~T}=80^{\circ} \mathrm{C}, t=180 \mathrm{~min}\end{array}$ & $\begin{array}{l}\text { DBT was easily removed, achieving over } 90 \% \text { conversion, } \\
\text { maintained for } 5 \text { cycles. BT and Th maximum removals were } 40 \% \text {. }\end{array}$ & [102] \\
\hline $\begin{array}{l}\text { DBT, } 4,6-\mathrm{DMDBT} \text { or } \mathrm{Th} \text { in } \\
\text { n-Octane }\left([\mathrm{S}]_{0}=500 \mu \mathrm{g} \mathrm{g}^{-1}\right)\end{array}$ & $\mathrm{MoO}_{2} / \mathrm{g}-\mathrm{C}_{3} \mathrm{~N}_{4}$ & IL: $[\mathrm{BMIM}]\left[\mathrm{BF}_{4}\right]$ & $\begin{array}{l}\mathrm{V}_{\text {fuel }}=5 \mathrm{~mL}, \mathrm{~V}_{\mathrm{IL}}=0.5-1.5 \\
\mathrm{~mL}, \mathrm{~m}_{\text {cat }}=0-0.03 \mathrm{~g}, \mathrm{~V}_{\mathrm{H} 2 \mathrm{O} 2}= \\
0-0.2 \mathrm{~mL}, \mathrm{~T}=50-80^{\circ} \mathrm{C}\end{array}$ & $\begin{array}{l}\text { Increasing loading of } \mathrm{MoO}_{2} \text { to } 3 \mathrm{wt} . \% \text { resulted in higher } \\
\text { desulfurization. A } 5 \mathrm{wt} . \% \text { loading negatively affected the S } \\
\text { removal. Temperatures higher than } 60{ }^{\circ} \mathrm{C} \text {, catalyst dosage over } \\
0.02 \mathrm{~g} \text {, and IL volume higher than } 1 \mathrm{~mL} \text { resulted in lower } \\
\text { desulfurization performances. Maximum removal was observed } \\
\text { with } 0.2 \mathrm{~mL} \text { of oxidant. Maximum conversions were } 95 \% \text { (DBT, } \\
120 \mathrm{~min}), 60 \% \text { (4,6-DMDBT, } 140 \mathrm{~min} \text { ) and } 35 \% \text { (Th, } 140 \mathrm{~min} \text { ). }\end{array}$ & [98] \\
\hline $\begin{array}{l}\text { BT, DBT, or } 4,6-\mathrm{DMDBT} \text { in } \\
\text { n-Octane }\left([\mathrm{S}]_{0}=800 \mathrm{ppm}\right)\end{array}$ & $\mathrm{MoO}_{\mathrm{x}} @ 3 \mathrm{D}-\mathrm{g}-\mathrm{C}_{3} \mathrm{~N}_{4}$ & Methyl cyanide & $\begin{array}{c}\mathrm{V}_{\text {fuel }}=30 \mathrm{~mL}, \mathrm{~V}_{\text {extractant }}=6 \\
\mathrm{~mL}, \mathrm{~m}_{\text {cat }}=0.005-0.01 \mathrm{~g} \\
\mathrm{~m}_{\mathrm{H} 2 \mathrm{O} 2}=0.15 \mathrm{~g}\left(\mathrm{H}_{2} \mathrm{O}_{2} / \mathrm{S}=5\right) \\
\mathrm{T}=0-60^{\circ} \mathrm{C}, t=75 \mathrm{~min}\end{array}$ & $\begin{array}{l}\text { Maximum desulfurization was 100\% for DBT, } 91 \% \text { for BT and } 91 \% \\
\text { for 4,6-DMDBT. }\end{array}$ & [99] \\
\hline $\begin{array}{l}\text { DBT, BT or Th in n-Octane } \\
\quad\left([S]_{0}=500 \mathrm{ppm}\right)\end{array}$ & $\mathrm{WO}_{3} / \mathrm{g}-\mathrm{C}_{3} \mathrm{~N}_{4}$ & $\begin{array}{l}\text { IL: 1-Ethyl-3- } \\
\text { Methylimidazolium } \\
\text { Diethylsulfate }\end{array}$ & $\begin{array}{c}\mathrm{V}_{\text {fuel }}=5 \mathrm{~mL}, \mathrm{~V}_{\mathrm{IL}}=0.25 \mathrm{~mL} \\
\mathrm{~m}_{\text {cat }}=0.03 \mathrm{~g}, \mathrm{~V}_{\mathrm{H} 2 \mathrm{O} 2}=0.3 \mathrm{~mL} \\
\mathrm{~T}=60^{\circ} \mathrm{C}, t=180 \mathrm{~min}\end{array}$ & $\begin{array}{l}\text { Increasing } \mathrm{WO}_{3} \text { loading to } 36 \% \text { results in an increase in } \\
\text { desulfurization. With } 50 \% \text { loading, the desulfurization was } \\
\text { negatively affected. A } 90 \% \text { conversion for DBT was observed (150 } \\
\text { min) and maintained for } 5 \text { cycles. Th Removal of } 60 \% \text { was } \\
\text { observed regardless of reaction time ( } 20-180 \text { min), and for BT a } \\
\text { maximum of } 43 \% \text { was obtained in } 180 \text { min. }\end{array}$ & [96] \\
\hline
\end{tabular}

Legend: $\mathrm{IL}=$ ionic liquid. $\mathrm{MeOH}=$ methanol. 
Table 9. Other ODS systems with carbon-based hybrid materials.

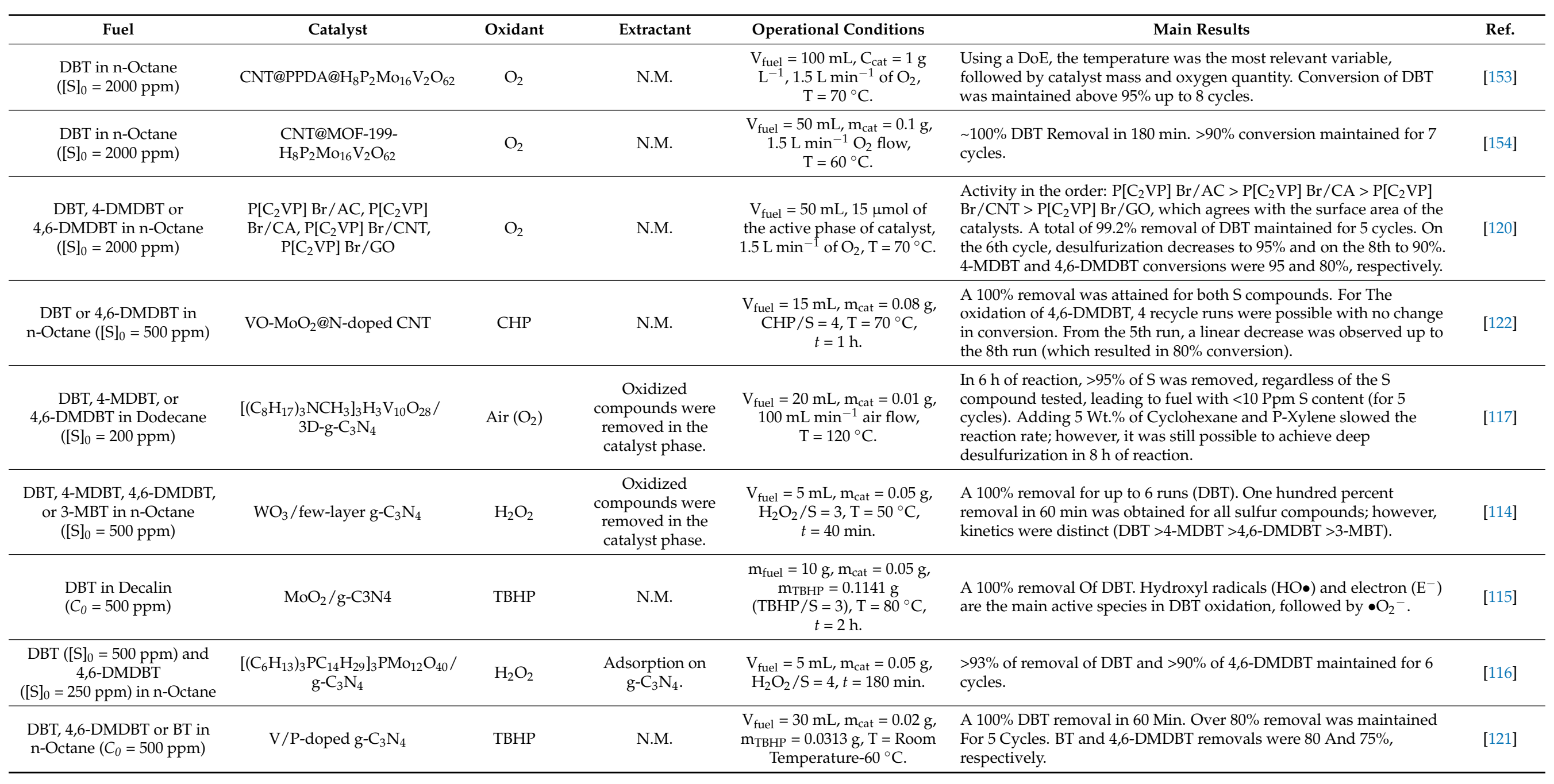


Table 9. Cont.

\begin{tabular}{|c|c|c|c|c|c|c|}
\hline Fuel & Catalyst & Oxidant & Extractant & Operational Conditions & Main Results & Ref. \\
\hline $\begin{array}{l}\text { DBT in n-Hexane } \\
\text { ([S }]_{0}=500 \mathrm{ppm} \text { ) and mixed } \\
\text { fuel of BT, DBT, and } \\
\text { 4,6-DMDBT ([S }]_{0}=125 \mathrm{ppm}, \\
\text { each) in n-Octane }\end{array}$ & $\mathrm{MoO}_{2} @ G N F$ & TBHP & N.M. & $\begin{array}{c}\mathrm{V}_{\text {fuel }}=5 \mathrm{~mL}, \mathrm{~m}_{\text {cat }}=5 \mathrm{mg} \\
\mathrm{V}_{\mathrm{TBHP}}=0.14 \mathrm{~mL}, \mathrm{~T}=60^{\circ} \mathrm{C} \\
t=120 \mathrm{~min} . \text { Solvent-Free. }\end{array}$ & $\begin{array}{l}\text { The synthesized catalyst acts as a Nanosponge for the oxidized } \\
\text { compounds; no extractant is required. Desulfurization achieved } \\
\text { values }>95 \% \text { for all components resulting in a final S content of } \\
6.5 \mathrm{ppm} \text {. }\end{array}$ & [129] \\
\hline $\begin{array}{l}\text { DBT, 4-MDBT, and } \\
\text { 4,6-DMDBT in Dodecane } \\
\left([\mathrm{S}]_{0}=200 \mathrm{mg} \mathrm{kg}^{-1}\right)\end{array}$ & $\mathrm{MoO}_{\mathrm{x}} / \mathrm{MC}$ & $\mathrm{O}_{2}$ & $\begin{array}{l}\text { Adsorption in the } \\
\text { catalyst. }\end{array}$ & $\begin{array}{c}\mathrm{V}_{\text {fuel }}=20 \mathrm{~mL}, \mathrm{~m}_{\text {cat }}=0.01 \mathrm{~g} \\
100 \mathrm{~mL} \mathrm{~min}^{-1} \text { of } \mathrm{O}_{2} \\
\mathrm{~T}=120^{\circ} \mathrm{C}\end{array}$ & $\begin{array}{l}\text { All compounds were completely removed within } 6 \mathrm{~h} \text { of reaction. DBT } \\
\text { displayed much faster kinetics compared to } 4 \text {-MDBT and } 4,6 \text {-DMDBT. } \\
\text { Upon adding other components of diesel in the simulated fuel } \\
\text { (Cyclohexane, Paraxylene, and 1-Octene), the desulfurization rate } \\
\text { decreased. However, it was still possible to achieve } 100 \% \text { removal, } \\
\text { requiring longer reaction times. }>98 \% \text { maintained for } 7 \text { cycles. }\end{array}$ & [155] \\
\hline $\begin{array}{l}\text { DBT, BT, or 4,6-DMDBT in } \\
\text { n-Octane }\left([S]_{0}=500 \mu \mathrm{g}\right. \\
\left.\mathrm{mL}^{-1}\right)\end{array}$ & $\mathrm{V}_{2} \mathrm{O}_{5} @ \mathrm{C}$ & $\mathrm{CHP}$ & N.M. & $\begin{array}{c}\mathrm{V}_{\text {fuel }}=10 \mathrm{~mL}, \mathrm{~m}_{\text {cat }}=50 \mathrm{mg} \\
\mathrm{V}_{\mathrm{CHP}}=0.17 \mathrm{~mL}, \mathrm{~T}=60^{\circ} \mathrm{C} \\
t=5 \mathrm{~h}\end{array}$ & $\begin{array}{l}\text { BT has the lowest desulfurization (63\%), followed by } 4,6 \text {-DMDBT } \\
(80 \%) \text { and DBT }(100 \%) \text {. Up to } 7 \text { cycles with no obvious decrease in } \\
\text { catalytic activity. }\end{array}$ & [156] \\
\hline $\begin{array}{l}\text { DBT in Tridecane } \\
\left(C_{0}=100-2000 \mu \mathrm{g} \mathrm{g}^{-1}\right)\end{array}$ & $\mathrm{FePc}\left(\mathrm{NO}_{2}\right)_{3}-\mathrm{CF}$ & $\mathrm{O}_{2}$ & N.M. & $\begin{array}{l}\mathrm{V}_{\text {fuel }}=25 \mathrm{~mL}, \mathrm{~m}_{\text {cat }}=0.25 \mathrm{~g} \\
0.2 \mathrm{MPa} \text { of } \mathrm{O}_{2} \text { initial } \\
\text { pressure, } \mathrm{T}=130^{\circ} \mathrm{C}\end{array}$ & $\begin{array}{l}\text { Upon increasing initial concentration, DBT conversion decreased } \\
\text { from } 100 \% \text { to } 60 \% \text { ( } 100 \text { and } 2000 \mathrm{Mg} \mathrm{G}^{-1} \text { initial DBT concentration, } \\
\text { respectively). }\end{array}$ & [118] \\
\hline $\begin{array}{c}\text { DBT, 4,6-DMDBT or BT in } \\
\text { n-Octane } \\
\left([\mathrm{S}]_{0}=250-500 \mathrm{ppm}\right)\end{array}$ & {$\left[\mathrm{PSPy}_{3} \mathrm{PMo}_{12} \mathrm{O}_{4} / \mathrm{GC}\right.$} & $\mathrm{H}_{2} \mathrm{O}_{2}$ & $\begin{array}{l}\text { Oxidized } \\
\text { Compounds were } \\
\text { removed in the } \\
\text { catalyst phase }\end{array}$ & $\begin{aligned} & \mathrm{V}_{\text {fuel }}= 5 \mathrm{~mL}, \mathrm{~m}_{\text {cat }}=0.05 \mathrm{~g} \\
& \mathrm{~V}_{\mathrm{H} 2 \mathrm{O} 2}= 24 \mu \mathrm{L}\left(\mathrm{H}_{2} \mathrm{O}_{2} / \mathrm{S}=3\right) \\
& \mathrm{T}=50^{\circ} \mathrm{C}\end{aligned}$ & $\begin{array}{l}\text { Removals were } 100 \%, 90 \% \text { and } 50 \% \text { for DBT, } 4,6-\mathrm{DMDBT} \text { and } \mathrm{BT} \text {, } \\
\text { respectively. Results were maintained for } 6 \text { cycles. }\end{array}$ & [128] \\
\hline $\begin{array}{l}\text { DBT, 4-MDBT or } \\
\text { 4,6-DMDBT in n-Octane } \\
\left([\mathrm{S}]_{0}=500 \mathrm{ppm}\right)\end{array}$ & $\mathrm{TiO}_{2} / \mathrm{GC}$ & $\mathrm{H}_{2} \mathrm{O}_{2}$ & $\begin{array}{l}\text { Oxidized } \\
\text { products } \\
\text { extracted in the } \\
\text { catalyst phase. }\end{array}$ & $\begin{array}{c}\mathrm{V}_{\text {fuel }}=5 \mathrm{~mL}, \mathrm{~m}_{\text {cat }}=0.01 \mathrm{~g} \\
\mathrm{~V}_{\mathrm{H} 2 \mathrm{O} 2}=32 \mu \mathrm{L}\left(\mathrm{H}_{2} \mathrm{O}_{2} / \mathrm{S}=4\right) \\
\mathrm{T}=50^{\circ} \mathrm{C}\end{array}$ & $\begin{array}{l}\text { With a } 10 \% \text { loading of } \mathrm{Tio}_{2} \text {, the best desulfurization performance was } \\
\text { observed ( } 100 \% \text { in } 40 \text { min maintained for } 10 \text { cycles). Desulfurization } \\
\text { for 4,6-DMDBT and 4-MDBT were } 77 \text { and } 99 \% \text {, respectively. Upon } \\
\text { adding } 5-10 \mathrm{Wt} \% \text { of P-Xylene in the fuel, desulfurization was not } \\
\text { greatly affected (100 and } 96 \% \text {, respectively). a slight decrease was } \\
\text { observed by adding } 5 \text { or } 10 \mathrm{Wt} \% \text { of cyclohexane ( } 85 \text { and } 75 \% \text {, } \\
\text { respectively). The radical } \bullet \mathrm{O}_{2}-\text { was found as the main active } \\
\text { constituent in the ODS of DBT. }\end{array}$ & [119] \\
\hline
\end{tabular}

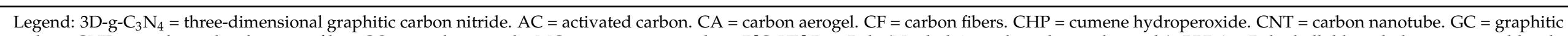

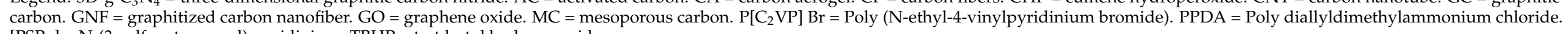
[PSPy] = N-(3-sulfonate propyl)-pyridinium. TBHP = tert-butyl hydroperoxide 
Table 10. ODS with carbon hybrid materials in photocatalytic systems.

\begin{tabular}{|c|c|c|c|c|c|c|}
\hline Fuel & Catalyst & Oxidant & Extractant & Operational Conditions & Main Results & Ref. \\
\hline $\begin{array}{c}\mathrm{DBT}\left([\mathrm{S}]_{0}=500 \mathrm{ppm}\right), \mathrm{BT} \\
\left([\mathrm{S}]_{0}=250 \mathrm{ppm}\right), \text { and RSH } \\
\left([\mathrm{S}]_{0}=250 \mathrm{ppm}\right) \text { in } \\
\text { Acetonitrile }\end{array}$ & $\mathrm{TiO}_{2} / \mathrm{g}-\mathrm{C}_{3} \mathrm{~N}_{4}$ & $\mathrm{H}_{2} \mathrm{O}_{2}$ & 1-Methyl-2-Pyrrolidone & $\begin{array}{c}\mathrm{V}_{\text {fuel }}=20 \mathrm{~mL}, \mathrm{~m}_{\text {cat }}=0.2 \mathrm{~g} \\
\mathrm{H}_{2} \mathrm{O}_{2} / \mathrm{S}=7, \mathrm{~T}=30^{\circ} \mathrm{C}, t=2 \mathrm{~h}, 250 \\
\text { W High-Pressure Hg Lamp. } \\
\text { 2-Step Process. }\end{array}$ & $\begin{array}{l}\text { S removal was higher in the } \\
\text { photocatalytic system. RSH } \\
\text { compounds were more easily } \\
\text { removed (100\%) compared to BT } \\
\text { and DBT }(90 \%) \text {. }\end{array}$ & [123] \\
\hline $\begin{array}{l}\text { DBT in n-Octane } \\
\left([S]_{0}=200 \mathrm{ppm}\right)\end{array}$ & $\begin{array}{l}\mathrm{CeO}_{2} / \text { Attapulgite/g- } \\
\mathrm{C}_{3} \mathrm{~N}_{4}\end{array}$ & $\mathrm{H}_{2} \mathrm{O}_{2}$ & $\mathrm{ACN}$ & $\begin{array}{c}\text { Mass Ratio Cat } / \mathrm{DBT}=1: 10, \text { Molar } \\
\text { Ratio } \mathrm{H}_{2} \mathrm{O}_{2} / \mathrm{DBT}=1: 4, t=3 \mathrm{~h}, 300 \\
\text { W Xenon Lamp. 2-Step Process }\end{array}$ & $\begin{array}{l}\text { A } 100 \% \text { removal of DBT. } \\
\text { Conversion maintained above } \\
90 \% \text { for up to } 8 \text { cycles. }\end{array}$ & [124] \\
\hline $\begin{array}{l}\text { DBT in n-octane } \\
\left([S]_{0}=200 \mathrm{ppm}\right)\end{array}$ & CQD/Attapulgite & $\mathrm{H}_{2} \mathrm{O}_{2}$ & $\mathrm{ACN}$ & $\begin{array}{c}\text { Mass Ratio Cat } / \text { Fuel = 1:1000, } \\
t=5 \mathrm{~h}, 300 \text { W Xenon Lamp. 2-Step } \\
\text { Process }\end{array}$ & A $92.3 \%$ removal of DBT. & [125] \\
\hline $\begin{array}{c}\text { Th in n-Octane }\left(C_{0}=800\right. \\
\mu \mathrm{L} L-1)\end{array}$ & $\mathrm{ZnTcPc} / \mathrm{g}-\mathrm{C}_{3} \mathrm{~N}_{4}$ & $\mathrm{O}_{2}$ & $\mathrm{CH}_{2} \mathrm{Cl}_{2}$ & $\begin{array}{c}\mathrm{V}_{\text {fuel }}=100 \mathrm{~mL}, \mathrm{~m}_{\text {cat }}=20 \mathrm{mg}, \\
\text { Visible Light Irradiation. 2-Step } \\
\text { Process. }\end{array}$ & A $85 \%$ removal of DBT in $90 \mathrm{~min}$. & [126] \\
\hline $\begin{array}{l}\text { DBT or } 4,6-\mathrm{DMDBT} \text { in } \\
\text { Tetradecane } \\
\left([\mathrm{S}]_{0}=200 \mathrm{ppm}\right)\end{array}$ & $\mathrm{CNT} / \mathrm{TiO}_{2}$ & NA & Adsorption with Silica. & $\begin{array}{l}\mathrm{V}_{\text {fuel }}=100 \mathrm{~mL}, \mathrm{~m}_{\text {cat }}=1 \mathrm{~g}, \\
\text { High-Pressure Hg Lamp. }\end{array}$ & $\begin{array}{l}\text { Desulfurization in simulated } \\
\text { Matrix: } 80 \% \text { for DBT and } 70 \% \text { for } \\
4,6-\text { DMDBT. }\end{array}$ & [127] \\
\hline $\begin{array}{l}\text { Commercial Diesel } \\
\left([\mathrm{S}]_{0}=714 \mathrm{ppm}\right)\end{array}$ & $\mathrm{CNT} / \mathrm{TiO}_{2}$ & NA & Adsorption with Silica. & $\begin{array}{l}\mathrm{V}_{\text {fuel }}=100 \mathrm{~mL}, \mathrm{~m}_{\text {cat }}=1 \mathrm{~g}, \\
\text { High-Pressure } \mathrm{Hg} \text { Lamp. }\end{array}$ & $\begin{array}{l}\text { S content decreased to } 0 \mathrm{ppm} \text { after } \\
120 \mathrm{~min} \text { of reaction. }\end{array}$ & [127] \\
\hline
\end{tabular}

Legend: $\mathrm{ACN}=$ acetonitrile. $\mathrm{CNT}=$ carbon nanotube. $\mathrm{g}-\mathrm{C}_{3} \mathrm{~N}_{4}=$ graphitic carbon nitride. $\mathrm{NA}=$ not applicable. 
Table 11. ODS with carbon-based materials as catalysts on their own.

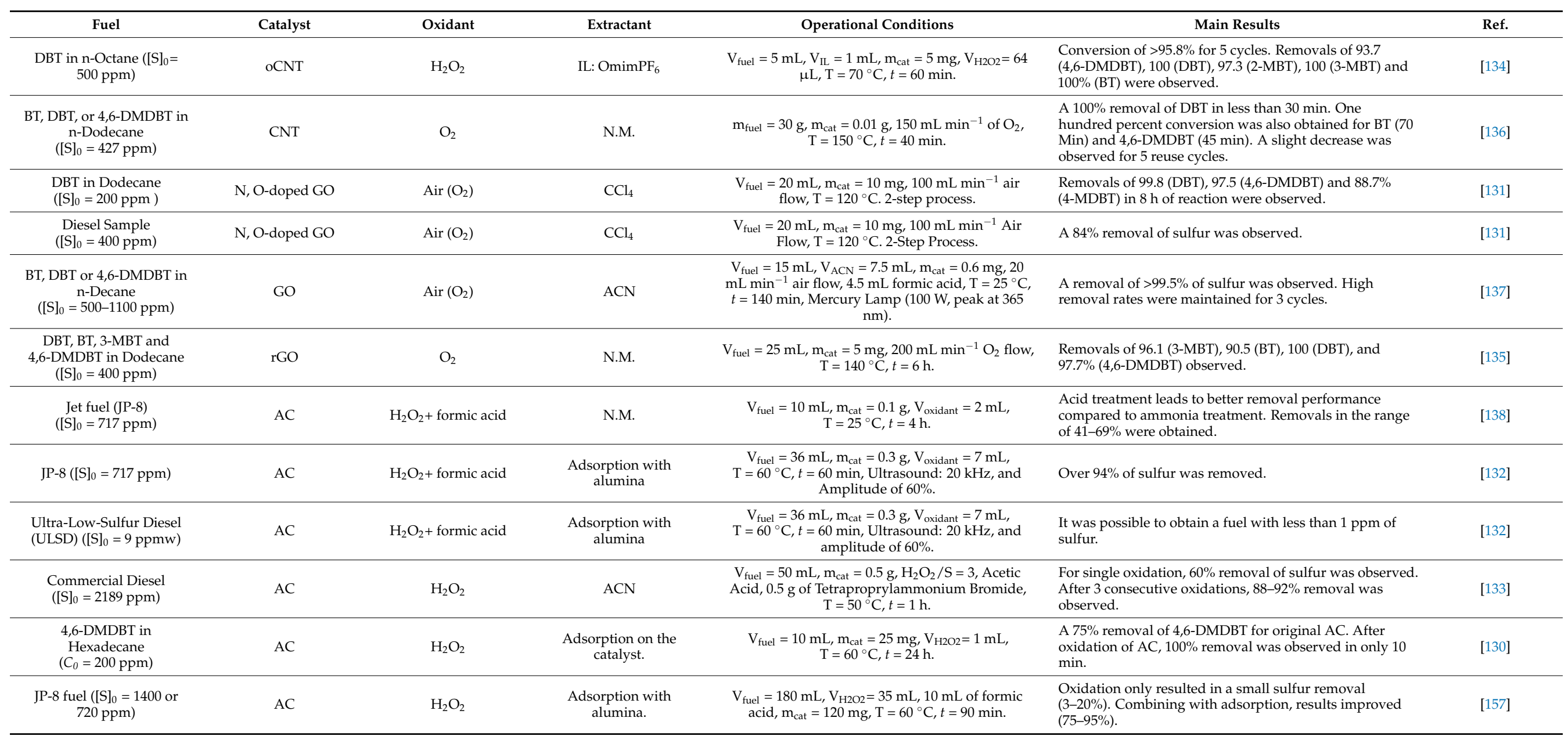

Legend: $\mathrm{N} . \mathrm{M} .=$ not mentioned. $\mathrm{AC}=$ activated carbon. $\mathrm{ACN}=$ acetonitrile. $\mathrm{CNT}=$ carbon nanotube $\mathrm{GO}=$ graphene oxide. $\mathrm{IL}=$ ionic liquid. $\mathrm{oCNT}=$ oxidized carbon nanotube. $\mathrm{rGO}=$ reduced GO. 
Table 12. ODS using $\mathrm{H}_{2} \mathrm{O}_{2}$ with amphiphilic carbon-based materials as catalysts.

\begin{tabular}{|c|c|c|c|c|c|}
\hline Fuel & Catalyst & Extractant & Operational Conditions & Main Results & Ref. \\
\hline $\begin{array}{l}\text { DBT in n-dodecane } \\
\left(C_{0}=100-1000 \mathrm{ppm}\right)\end{array}$ & $\mathrm{GO} / \mathrm{COOH}$ & Adsorption & $\begin{array}{c}\mathrm{V}_{\text {fuel }}=25 \mathrm{~mL}, \mathrm{~m}_{\text {cat }}=0.05 \mathrm{~g}, \mathrm{~V}_{\mathrm{H} 2 \mathrm{O} 2}=5 \\
\mathrm{~mL}, \mathrm{~T}=273-313 \mathrm{~K}, 20 \mathrm{kHz} \\
\text { Ultrasound Apparatus at } 120 \mathrm{~W}\end{array}$ & $\begin{array}{l}\text { A } 95 \% \text { removal of sulfur was achieved for an } \\
\text { initial concentration of DBT of } 1000 \mathrm{ppm} \text {. }\end{array}$ & [139] \\
\hline $\begin{array}{c}\text { Two Real Oil Samples } \\
\left([\mathrm{S}]_{0}=968.72 \text { and } 2668.78 \mathrm{ppm}\right)\end{array}$ & $\mathrm{PW}_{12} \mathrm{O}_{40}-/ \mathrm{C}-\mathrm{Si}$ & $\mathrm{ACN}$ & $\begin{array}{l}\mathrm{V}_{\text {fuel }}=1 \mathrm{~mL}, \mathrm{~V}_{\mathrm{ACN}}=1 \mathrm{~mL}, 4 \mathrm{wt} . \% \text { of } \\
\text { catalyst, } \mathrm{H}_{2} \mathrm{O}_{2} / \mathrm{S}=6, \mathrm{~T}=60^{\circ} \mathrm{C}, 5 \mathrm{~min} \\
\text { in US to form an emulsion, } t=1 \mathrm{~h} .\end{array}$ & $\begin{array}{l}\text { Three consecutive cycles of ODS resulted in s } \\
\text { content lower than } 10 \mathrm{ppm} \text {. }\end{array}$ & [147] \\
\hline $\begin{array}{l}\text { DBT in Cyclohexane } \\
\left([\mathrm{S}]_{0}=50 \mathrm{ppm}\right)\end{array}$ & $\mathrm{Fe} / \mathrm{C}$ and $\mathrm{FeMo} / \mathrm{C}$ & Aqueous $\mathrm{H}_{2} \mathrm{O}_{2}$ Phase & $\begin{array}{l}\mathrm{V}_{\text {fuel }}=5 \mathrm{~mL}, \mathrm{~m}_{\text {cat }}=15 \mathrm{mg}, \mathrm{V}_{\mathrm{H} 2 \mathrm{O} 2}=1 \\
\mathrm{~mL}, \mathrm{~T}=25^{\circ} \mathrm{C}, t=120 \mathrm{~min} . \text { Emulsion }\end{array}$ & $>60 \%$ conversion of DBT for up to 3 cycles. & [143] \\
\hline DBT in n-Octane $\left([S]_{0}=250\right.$ ppm $)$ & $\mathrm{SiO}_{2} @ \mathrm{C}$-dots $/\left[\mathrm{PW}_{12} \mathrm{O}_{38}\right]^{3-}$ & $\mathrm{ACN}$ & $\begin{array}{c}\mathrm{V}_{\text {fuel }}=60 \mathrm{~mL}, \mathrm{~V}_{\mathrm{ACN}}=60 \mathrm{~mL} \\
\mathrm{~m}_{\text {cat }}=0.2 \mathrm{~g}, \text { Molar Ratio } \\
\mathrm{H}_{2} \mathrm{O}_{2} / \mathrm{DBT}=3, \mathrm{~T}=60^{\circ} \mathrm{C}, t=3 \mathrm{~h}\end{array}$ & $100 \%$ removal of DBT in $180 \mathrm{~min}$. & [158] \\
\hline $\begin{array}{l}\text { DBT in Cyclohexane } \\
\left([S]_{0}=50 \mathrm{ppm}\right)\end{array}$ & $\mathrm{Si}-\mathrm{C}$ & Aqueous $\mathrm{H}_{2} \mathrm{O}_{2}$ Phase & $\begin{array}{c}\mathrm{V}_{\text {fuel }}=5 \mathrm{~mL}, \mathrm{~m}_{\text {cat }}=10 \mathrm{mg}, \mathrm{V}_{\mathrm{H} 2 \mathrm{O} 2}=1 \\
\mathrm{~mL}, t=180 \text { min. Emulsion }\end{array}$ & Maximum removal of $15 \mathrm{mg}_{\mathrm{S}} \mathrm{g}_{\mathrm{cat}}{ }^{-1}$ observed & [144] \\
\hline Diesel S1800 ([S $]_{0}=1800$ ppm) & $\mathrm{Si}-\mathrm{C}$ & Aqueous $\mathrm{H}_{2} \mathrm{O}_{2}$ Phase & $\begin{array}{c}\mathrm{V}_{\text {fuel }}=5 \mathrm{~mL}, \mathrm{~m}_{\text {cat }}=10 \mathrm{mg}, \mathrm{V}_{\mathrm{H} 2 \mathrm{O} 2}=1 \\
\mathrm{~mL}, t=180 \text { min. Emulsion }\end{array}$ & A $57 \%$ removal of sulfur in Diesel S1800. & [144] \\
\hline DBT in n-Octane $\left(C_{0}=800 \mathrm{ppm}\right)$ & $\mathrm{H}_{3} \mathrm{PMo}_{12} \mathrm{O}_{40} / \mathrm{AmHMSiO}_{2} @ \mathrm{C}$ & $\mathrm{ACN}$ & $\begin{array}{c}\mathrm{V}_{\text {fuel }}=2 \mathrm{~mL}, \mathrm{~V}_{\mathrm{ACN}}=2 \mathrm{~mL} \\
\mathrm{n}_{\text {cat }}=0.002 \mathrm{mmol}, \mathrm{n}_{\mathrm{H} 2 \mathrm{O} 2}=0.15 \mathrm{mmol} \\
\mathrm{T}=40^{\circ} \mathrm{C}, t=3 \mathrm{~h} .\end{array}$ & $\begin{array}{l}>99 \% \text { conversion was obtained in } 180 \mathrm{~min} \\
\text { and maintained for } 5 \text { cycles. }\end{array}$ & [140] \\
\hline $\begin{array}{l}\text { DBT }\left(C_{0}=500 \mathrm{ppm}\right), 4-\mathrm{MDBT} \\
\left(C_{0}=200 \mathrm{pm}\right), 4,6-\mathrm{DMDBT} \\
\left(C_{0}=200 \mathrm{ppm}\right) \text { in Dodecane }\end{array}$ & $\mathrm{g}-\mathrm{C}_{3} \mathrm{~N}_{4}$ & Adsorption & $\begin{array}{c}\mathrm{V}_{\text {fuel }}=5 \mathrm{~mL}, \mathrm{~m}_{\text {cat }}=0.05 \mathrm{~g} \\
\mathrm{H}_{2} \mathrm{O}_{2} / \mathrm{S}=4, \mathrm{~T}=60^{\circ} \mathrm{C}, t=60 \mathrm{~min}, \\
800 \mathrm{rpm} .\end{array}$ & $\begin{array}{l}\text { A } 100 \% \text { removal of DBT and } \sim 80 \% \text { for } \\
4 \text {-MDBT and 4.6-DMDBT. }\end{array}$ & [141] \\
\hline $\begin{array}{l}\text { Th and DBT in Cyclohexane } \\
\qquad\left(C_{0}=100 \mathrm{ppm}\right)\end{array}$ & $\mathrm{CNT} / \mathrm{red}$ mud & Aqueous $\mathrm{H}_{2} \mathrm{O}_{2}$ Phase & $\begin{array}{c}\mathrm{V}_{\text {fuel }}=5 \mathrm{~mL}, \mathrm{~m}_{\text {cat }}=20 \mathrm{mg}, \mathrm{V}_{\mathrm{H} 2 \mathrm{O} 2}=1 \\
\mathrm{~mL}, \text { Emulsion }\end{array}$ & $67 \%$ removal of Th and $82 \%$ of DBT in $1 \mathrm{~h}$. & [145] \\
\hline $\begin{array}{l}\text { DBT in Cyclohexane } \\
\quad\left(C_{0}=500 \mathrm{ppm}\right)\end{array}$ & $\mathrm{FeMo} / \mathrm{CNT}$ & Aqueous $\mathrm{H}_{2} \mathrm{O}_{2}$ Phase & $\begin{array}{c}\mathrm{V}_{\text {fuel }}=5 \mathrm{~mL}, \mathrm{~m}_{\text {cat }}=20 \mathrm{mg}, \mathrm{V}_{\mathrm{H} 2 \mathrm{O} 2}=1 \\
\mathrm{~mL}, \text { Emulsion }\end{array}$ & $\begin{array}{l}\text { Oxidation Efficiency Varied Between } \\
20-100 \% \text {. }\end{array}$ & {$[146]$} \\
\hline
\end{tabular}


Table 12. Cont

\begin{tabular}{|c|c|c|c|c|c|}
\hline Fuel & Catalyst & Extractant & Operational Conditions & Main Results & Ref. \\
\hline $\begin{array}{l}\text { DBT in n-dodecane } \\
\left(C_{0}=100-1000 \mathrm{ppm}\right)\end{array}$ & $\mathrm{GO} / \mathrm{COOH}$ & Adsorption & $\begin{array}{c}\mathrm{V}_{\text {fuel }}=25 \mathrm{~mL}, \mathrm{~m}_{\text {cat }}=0.05 \mathrm{~g}, \mathrm{~V}_{\mathrm{H} 2 \mathrm{O} 2}=5 \\
\mathrm{~mL}, \mathrm{~T}=273-313 \mathrm{~K}, 20 \mathrm{kHz} \\
\text { Ultrasound Apparatus at } 120 \mathrm{~W}\end{array}$ & $\begin{array}{l}\text { A } 95 \% \text { removal of sulfur was achieved for an } \\
\text { initial concentration of DBT of } 1000 \mathrm{ppm} \text {. }\end{array}$ & [139] \\
\hline DBT in toluene $\left(C_{0}=50 \mathrm{ppm}\right)$ & $\mathrm{Fe}_{2} \mathrm{O}_{3} / \mathrm{C}$ & $\mathrm{MeOH}$ & $\begin{array}{c}\mathrm{V}_{\text {fuel }}=9.9 \mathrm{~mL}, \mathrm{~m}_{\text {cat }}=10 \mathrm{mg} \\
\mathrm{V}_{\text {oxidant }}=0.1 \mathrm{~mL}\left(\mathrm{H}_{2} \mathrm{O}_{2} / \mathrm{HCOOH}\right. \\
(1: 1 \mathrm{~mol} / \mathrm{mol})), \mathrm{T}=25^{\circ} \mathrm{C} .2 \text {-Step } \\
\text { Process. }\end{array}$ & $\begin{array}{l}\text { A } 97 \% \text { Conversion of DBT in } 180 \text { min of } \\
\text { reaction, with a yield towards sulfones of } \\
\sim 60 \% \text {. In the presence of QN, the yield } \\
\text { towards the sulfone decreased to below } 40 \% \text {. }\end{array}$ & [159] \\
\hline $\begin{array}{l}\text { DBT in cyclohexane } \\
\quad\left([\mathrm{S}]_{0}=50 \mathrm{ppm}\right)\end{array}$ & $\mathrm{Au} / \mathrm{RmEtb}$ & Aqueous $\mathrm{H}_{2} \mathrm{O}_{2}$ Phase & $\begin{array}{c}\mathrm{V}_{\text {fuel }}=5 \mathrm{~mL}, \mathrm{~m}_{\mathrm{cat}}=20 \mathrm{mg}, \mathrm{V}_{\mathrm{H} 2 \mathrm{O} 2}=1 \\
\mathrm{~mL}\end{array}$ & $\begin{array}{l}\text { The highest removal rate of DBT was attained } \\
\text { with the catalyst containing a carbon coating } \\
\text { due to the amphiphilic characteristics } \\
\text { (removal of } \sim 4.5 \mathrm{mgs} \mathrm{g}_{\text {cat }}{ }^{-1} \text { ) }\end{array}$ & [160] \\
\hline $\begin{array}{l}\text { Th, BT and DBT in n-Heptane } \\
\quad\left([\mathrm{S}]_{0}=500 \mathrm{ppm}\right)\end{array}$ & $\mathrm{C}_{3} \mathrm{~N}_{2} \mathrm{H}_{5} @ \mathrm{H}_{3} \mathrm{PMo}_{12} \mathrm{O}_{40} @ \mathrm{CS}$ & $\mathrm{ACN}$ & $\begin{array}{c}\mathrm{V}_{\text {fuel }}=50 \mathrm{~mL}, \mathrm{~m}_{\text {cat }}=0.1 \mathrm{~g} \\
\mathrm{~V}_{\text {oxidant }}=3 \mathrm{~mL}\left(\mathrm{H}_{2} \mathrm{O}_{2} / \text { acetic acid }\right), \\
\mathrm{T}=30-35^{\circ} \mathrm{C}, t=1 \text { h. } 2 \text {-step process }\end{array}$ & $\begin{array}{l}>96 \% \text { removal of } \mathrm{S} \text { was possible depending } \\
\text { on the condition applied. }\end{array}$ & [161] \\
\hline
\end{tabular}

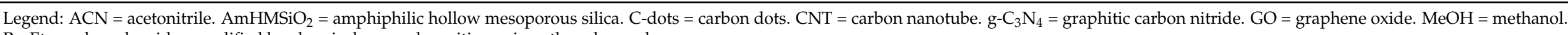
$\mathrm{RmEt}=$ red mud residue modified by chemical vapor deposition using ethanol as carbon source. 


\section{Carbon Materials in ODN}

Denitrogenation reactions are not as widely studied as desulfurization, and thus there is a limited number of papers regarding denitrogenation with carbon-based materials. In general, the roles of the carbon-based materials in ODS are similar in ODN reactions. Many authors highlighted the amphiphilicity of carbon structures as beneficial in ODN reactions. Table 13 summarizes the papers related to ODN reactions. As observed, most of the works deal with ODN of QN (model component most extensively studied). ODN is mainly conducted with $\mathrm{H}_{2} \mathrm{O}_{2}$ using iron-containing carbon materials under mild conditions $\left(25-80^{\circ} \mathrm{C}\right.$ ) for reaction times up to $3 \mathrm{~h}$ (achieving complete oxidation of the model molecule at lower times depending on the selected catalyst and operating conditions). The selection of iron catalyst with $\mathrm{H}_{2} \mathrm{O}_{2}$ as oxidant may be ascribed to the reactive iron- $\mathrm{H}_{2} \mathrm{O}_{2}$ pair, also known as Fenton-reagent [162,163].

Guimarães et al. (2013) have tested magnetite covered by carbon as the catalyst for the simultaneous oxidation of DBT and QN in a biphasic system (toluene-acetonitrile, $\left.[\mathrm{QN}]_{0}=50 \mathrm{ppm}\right)[159]$. DBT conversion was higher than $\mathrm{QN}$ conversion $(100 \%$ instead of $\sim 60 \%$ for $\mathrm{QN}$ ). The presence of DBT reduced QN oxidation by about $50 \%$. The authors have highlighted the amphiphilicity of the catalyst and its ability to remain in the interface between the two solvents as one of the critical conditions to display high catalytic activity [159].

Mambrini et al. (2017) studied the removal of $\mathrm{QN}$ in cyclohexane ([N $\left.]_{0}=50 \mathrm{ppm}\right)[143]$ in a PIC-like system using a FeMo/C as the catalyst. Due to the amphiphilic character of the catalyst, it can interact with aqueous and oily phases, stabilizing an emulsion cyclohexaneaqueous $\mathrm{H}_{2} \mathrm{O}_{2}$. The emulsified system increases the interfacial area and enhances the reaction rate. The high interfacial area resulted in a very fast conversion of $\mathrm{QN}$ : almost complete conversion in less than $10 \mathrm{~min}$ [143]. FeMo/C revealed a higher catalytic activity than $\mathrm{Fe} / \mathrm{C}$, which was ascribed to the higher content of carbon on FeMo/C. Higher carbon content allowed a better interaction between the oily and the aqueous phase, favoring emulsion stabilization [143].

Oliveira et al. (2014) prepared amphiphilic catalysts through the modification of red mud by chemical vapor deposition (CVD) of ethanol [145]. The materials were tested in the PIC-like oxidation of QN in cyclohexane with $\mathrm{H}_{2} \mathrm{O}_{2}$. Within $60 \mathrm{~min}, \mathrm{QN}$ was removed entirely, and this activity was maintained for 5 cycles. They ascribed the exciting results to the amphiphilicity resulting from the carbon deposits after CVD, which allowed the stabilization of the emulsified system, increasing the contact between the organic and the aqueous phases [145]. Similar materials were synthesized by Teixeira et al. (2013) [146] and applied in the biphasic oxidation of QN in a PIC-like system. One hundred percent oxidation of QN was possible in less than $30 \mathrm{~min}$ of reaction. The efficiency of the reaction system was maintained for 5 cycles [146].

Souza, Pereira, and Oliveira (2012) produced amphiphilic catalysts based on onionlike carbon (OLC) over iron oxide and applied them in the biphasic oxidation of QN in toluene [164]. Ninety three percent removal of QN was obtained. The activity of the material was ascribed to increased contact between the aqueous oily phases due to the presence of a hydrophobic carbon layer on the catalyst [164].

Oliveira et al. (2020) prepared N-doped CNTs over red mud and applied them in the biphasic oxidation of QN in cyclohexane ([N] $]_{0}$ of $30 \mathrm{ppm}$ ) with $\mathrm{H}_{2} \mathrm{O}_{2}$ [165]. The catalysts were synthesized sequentially feeding ethylene (as carbon source) and acetonitrile (as carbon and nitrogen sources), leading to 4 different samples. (i) A completely undoped (synthesized using only ethylene); (ii) a completely $\mathrm{N}$-doped (synthesized using only acetonitrile); and (iii) two samples synthesized using both precursors during different times, leading to two partially N-doped samples. QN oxidation varied according to the content of nitrogenated groups on the material: higher $\mathrm{N}$ contents led to increased removal of QN (80\% versus $44 \%)$ [165]. A study with similar materials was previously done by Purceno et al. (2015) [166]. However, the selectively N-doped CNTs acted only as emulsion stabilizers in their case, and a homogeneous catalyst $\left(\mathrm{Fe}^{+2}\right)$ was applied. Without the 
presence of the CNTs, only $10 \%$ of $\mathrm{QN}$ was removed. On the other hand, by adding amphiphilic CNTs, a removal of QN in the range $85-100 \%$ was observed in 15-40 min of reaction, depending on the CNT sample. The results were directly ascribed to the ability of amphiphilic CNTs to stabilize Pickering emulsions, increasing interfacial area [166].

Ammar, Kareem, and Mohammed (2020) studied exclusively the ultrasound-assisted catalytic oxidative-adsorptive denitrogenation (COADN) of pyrrole (PYR) and indole (IND) (dissolved in n-nonane, [PYR $]_{0}$ and [IND] $]_{0}$ of $200 \mathrm{ppm}$ ) [167] using a $\mathrm{PMo}-\mathrm{Fe}_{2} \mathrm{O}_{3} / \mathrm{rGO}$ as the catalyst. Upon increasing sonication power and time, oxidation of $\mathrm{N}$ compounds increased. The best results were obtained with $200 \mathrm{~W}$ ultrasound power for $240 \mathrm{~min}$, leading to 86 and 90\% conversion for PYR and IND, respectively. Compared to the silent reaction (no ultrasound), an increase in 50 and 58\% removals for PYR and IND, respectively, were observed. This high conversion was maintained for up to 5 cycles [167]. The authors did not highlight the role of the carbon structure.

Raffie and Khodayari (2017) added N compounds to a simulated fuel containing DBT in order to investigate the influence of the presence of $\mathrm{N}$ compounds (IND, QN, pyridine, and pyrrole, $C_{0}=60 \mathrm{ppm}$ ) in the removal of DBT using a catalyst containing $\mathrm{PMoV} / \mathrm{Fe}_{3} \mathrm{O}_{4} / \mathrm{g}-\mathrm{C}_{3} \mathrm{~N}_{4}$ [76]. All nitrogenated compounds were oxidized in very short reaction times (20 min). Although the presence of N compounds slowed DBT oxidation, the effect was minimal. Thus, proving that desulfurization and denitrogenation can be conducted simultaneously for the proposed system [76]. A similar study was performed previously by the same group [84] using an $\mathrm{HPW} / \mathrm{TiO}_{2} / \mathrm{GC}$ catalyst. They have also concluded that the addition of nitrogenated compounds slightly impacts DBT removal. However, they have not reported the conversion of those nitrogenated compounds in the system.

Bhadra et al. (2019) studied the denitrogenation of a simulated fuel containing a range of different $\mathrm{N}$ compounds (IND, 1-, 2- and 3-methyl-substituted indoles (1-MeIND, 2-Me-IND, and 3-Me-IND, respectively), PYR, carbazole (CBZ), and QN in n-octane, $C_{0}=5000 \mathrm{ppm}$ ) [168]. The biphasic oxidation was conducted in the presence of acetic acid and with $\mathrm{H}_{2} \mathrm{O}_{2}$ as the oxidant. For IND, upon increasing the $\mathrm{H}_{2} \mathrm{O}_{2} / \mathrm{N}$ ratio and catalyst dosage up to a certain point $\left(\mathrm{H}_{2} \mathrm{O}_{2} / \mathrm{N}=10\right.$ and catalyst concentration of $\left.0.25 \mathrm{~g} \mathrm{~L}^{-1}\right)$, IND removal increased. However, further increasing any of those parameters did not have a significant impact on IND removal. The removal of the remaining $\mathrm{N}$ compounds was also investigated. In $120 \mathrm{~min}$ of reaction, $90 \%$ of IND was removed (maintained for 4 cycles), followed closely by 2-Me-IND. Removals of 1-Me-IND and 3-Me-IND were $\sim 70 \%$, whereas PYR and CBZ removals were $40 \%$ and $<20 \%$, respectively. QN was not oxidized in the studied conditions. The distinction between the oxidation rate of different compounds was ascribed to the electron density around the $\mathrm{N}$ atom, similar to that observed with $\mathrm{S}$ compounds. However, the authors have highlighted that further studies are necessary to truly understand the relation between electron density in $\mathrm{N}$ compounds and reaction rate [168]. The authors did not highlight the role of the carbon structure. 
Table 13. ODN reactions using carbon-based materials and $\mathrm{H}_{2} \mathrm{O}_{2}$ as oxidant.

\begin{tabular}{|c|c|c|c|c|c|}
\hline Fuel & Catalyst & Extractant & Operational Conditions & Main Results & Ref. \\
\hline $\begin{array}{l}\text { IND or PYR in n-Nonane } \\
\quad\left(C_{0}=50-800 \mathrm{ppm}\right)\end{array}$ & $\mathrm{H}_{3} \mathrm{PMo}_{12} \mathrm{O}_{40}-\mathrm{Fe}_{3} \mathrm{O}_{4} / \mathrm{rGO}$ & Aqueous $\mathrm{H}_{2} \mathrm{O}_{2}$ phase & $\begin{array}{l}\mathrm{V}_{\text {fuel }}=50 \mathrm{~mL}, \mathrm{C}_{\text {cat }}=0-2 \mathrm{~g} \mathrm{~L}^{-1} \\
\text { Molar Ratio } \mathrm{H}_{2} \mathrm{O}_{2} / \mathrm{PYR}=0-10 \\
t=15-240 \mathrm{~min}, \mathrm{US}: 50-300 \mathrm{~W}\end{array}$ & $\begin{array}{l}\text { Increasing ultrasound (US) power (to } 200 \mathrm{~W} \text { ) increases } \\
\text { denitrogenation (max. } 90 \% \text { in } 240 \text { min). Increasing the } \\
\mathrm{H}_{2} \mathrm{O}_{2} \text { /PYR molar ratio over } 5 \text { did not increase n removal. } \\
\text { Five cycles of reuse were possible. }\end{array}$ & [167] \\
\hline $\begin{array}{l}\mathrm{QN} \text { in Toluene }\left(C_{0}=100 \mathrm{ppm} \text { in }\right. \\
\text { the presence of } 50 \mathrm{ppm} \text { of DBT) }\end{array}$ & $\mathrm{Fe}_{2} \mathrm{O}_{3} / \mathrm{C}$ & Aqueous $\mathrm{H}_{2} \mathrm{O}_{2}$ phase & $\begin{array}{c}\mathrm{V}_{\text {fuel }}=9.9 \mathrm{~mL}, \mathrm{~m}_{\text {cat }}=10 \mathrm{mg} \\
\mathrm{V}_{\text {oxidant }}=0.1 \mathrm{~mL} \\
\left(\mathrm{H}_{2} \mathrm{O}_{2} / \mathrm{HCOOH}\right), \mathrm{T}=25^{\circ} \mathrm{C}, \mathrm{pH} \\
4 \text { (natural } \mathrm{pH})\end{array}$ & $\begin{array}{l}\text { Approximately } 60 \% \text { removal of QN. The presence of DBT } \\
\text { inhibited the complete removal of QN. }\end{array}$ & [159] \\
\hline $\begin{array}{l}\text { QN in Cyclohexane } \\
\left([\mathrm{N}]_{0}=30 \mathrm{ppm}\right)\end{array}$ & N-Doped CNT/Red Mud & Aqueous $\mathrm{H}_{2} \mathrm{O}_{2}$ phase & $\begin{array}{c}\mathrm{V}_{\text {fuel }}=5 \mathrm{~mL}, \mathrm{~m}_{\text {cat }}=20 \mathrm{mg} \\
\mathrm{V}_{\mathrm{H} 2 \mathrm{O} 2}=1 \mathrm{~mL}\end{array}$ & Maximum removal of $80 \%$ in $45 \mathrm{~min}$ of reaction. & [165] \\
\hline $\begin{array}{l}\text { DBT + IND, Quinolone, PYR, } \\
\text { Pyrrole in EtOH: Hexane (1:1 vol. } \\
\text { ratio) }\left(C_{0}=60 \mathrm{ppm} \text { in the }\right. \\
\text { presence of } 1000 \mathrm{ppm} \text { of DBT })\end{array}$ & $\mathrm{H}_{5} \mathrm{PMo}_{10} \mathrm{~V}_{2} \mathrm{O}_{40} / \mathrm{Fe}_{3} \mathrm{O}_{4} / \mathrm{g}-\mathrm{C}_{3} \mathrm{~N}_{4}$ & $\mathrm{EtOH}$ & $\begin{aligned} \mathrm{V}_{\text {fuel }} & =5 \mathrm{~mL}, \mathrm{~m}_{\text {cat }}=0.03 \mathrm{~g} \\
\mathrm{n}_{\mathrm{H} 2 \mathrm{O} 2} & =10 \mathrm{mmol}, \mathrm{T}=80^{\circ} \mathrm{C}\end{aligned}$ & $\begin{array}{l}\text { All N-containing compounds were wholly oxidized in } 20 \\
\text { min of reaction. Their presence did not affect to a great } \\
\text { extent the removal of DBT. }\end{array}$ & [76] \\
\hline $\begin{array}{l}\text { QN in Cyclohexane } \\
\left(C_{0}=500 \mathrm{ppm}\right)\end{array}$ & $\begin{array}{l}\text { WEEE Impregnated in Clay and } \\
\text { Hydrophobized with CTAB. }\end{array}$ & $\mathrm{ACN}$ & $\begin{array}{c}\mathrm{V}_{\text {fuel }}=10 \mathrm{~mL}, \mathrm{~V}_{\mathrm{ACN}}=2 \mathrm{~mL} \\
\mathrm{~V}_{\mathrm{H} 2 \mathrm{O} 2}=320 \mu \mathrm{L}, \mathrm{T}=60^{\circ} \mathrm{C}, t=3 \mathrm{~h} .\end{array}$ & A maximum removal rate of $73.5 \mathrm{mg}_{\mathrm{QN}} \mathrm{g}_{\mathrm{cat}}{ }^{-1}$ & [169] \\
\hline $\begin{array}{l}\text { IND, } 1 \mathrm{Me}-\mathrm{IND}, 2 \mathrm{Me}-\mathrm{IND} \\
\text { 3Me-IND, PYR, QN, or CBZ in } \\
\text { n-Octane }\left(C_{0}=5000 \mathrm{ppm}\right)\end{array}$ & $\mathrm{TiO}_{2} @$ porous $\mathrm{C}$ & Acetic Acid & $\begin{array}{c}\mathrm{V}_{\text {fuel }}=20 \mathrm{~mL}, \mathrm{~V}_{\text {extractant }}=2 \mathrm{~mL} \\
\mathrm{C}_{\text {cat }}=0-0.5 \mathrm{~g} \mathrm{~L}^{-1} \\
\mathrm{H}_{2} \mathrm{O}_{2} / \mathrm{N}=0-15, \mathrm{~T}=30-50{ }^{\circ} \mathrm{C} \\
t=5-120 \mathrm{~min}, 100-1000 \mathrm{rpm} \\
5-10 \text { wt. } \% \text { water. }\end{array}$ & $\begin{array}{l}\text { Increasing } \mathrm{O} / \mathrm{N} \text { up to } 10 \text { and catalyst dosage up to } 0.25 \mathrm{~g} \\
\mathrm{~L}^{-1} \text { results in an increase in } \mathrm{N} \text { removal. Further increasing } \\
\text { those values does not alter the results. Denitrogenation } \\
\text { varied between } 15-90 \% \text {, depending on the } \mathrm{N} \text { compound. } \\
\text { Similar results were maintained for } 4 \text { cycles. }\end{array}$ & [168] \\
\hline $\begin{array}{l}\text { QN in Cyclohexane } \\
\left(C_{0}=500 \mathrm{ppm}\right)\end{array}$ & $\mathrm{C} / \mathrm{red}$ mud & Aqueous $\mathrm{H}_{2} \mathrm{O}_{2}$ Phase & $\begin{array}{c}\mathrm{V}_{\text {fuel }}=5 \mathrm{~mL}, \mathrm{~m}_{\text {cat }}=20 \mathrm{mg}, \\
\mathrm{V}_{\mathrm{H} 2 \mathrm{O} 2}=1 \mathrm{~mL}\end{array}$ & $100 \%$ removal of $\mathrm{QN}$ in $60 \mathrm{~min}$ of reaction. & [145] \\
\hline $\begin{array}{l}\text { QN in Cyclohexane } \\
\left(C_{0}=500 \mathrm{ppm}\right)\end{array}$ & $\mathrm{FeCl}_{2} \cdot 4 \mathrm{H}_{2} \mathrm{O}$ & Aqueous $\mathrm{H}_{2} \mathrm{O}_{2}$ Phase & $\begin{array}{c}\mathrm{V}_{\text {fuel }}=5 \mathrm{~mL}, \mathrm{C}_{\text {cat }}=5.6 \mathrm{mmol} \mathrm{L} \\
-1 \text { and } 1 \mathrm{wt} . \% \mathrm{CNT}, \mathrm{V}_{\mathrm{H} 2 \mathrm{O} 2}=300 \\
\mu \mathrm{L}, 300 \mu \mathrm{L} \text { of formic acid, } 20 \mathrm{~s} \\
\text { sonication to form an emulsion. }\end{array}$ & $\begin{array}{l}\text { Depending on the Sample (i.e., whether it is amphiphilic), } \\
100 \% \text { removal of QN is observed in } 15 \mathrm{~min} \text {. }\end{array}$ & [166] \\
\hline $\mathrm{QN}$ in Toluene $\left(C_{0}=25 \mathrm{ppm}\right)$ & $\mathrm{Fe} / \mathrm{OLC}$ & Aqueous $\mathrm{H}_{2} \mathrm{O}_{2}$ Phase & $\begin{array}{c}\mathrm{V}_{\text {fuel }}=10 \mathrm{~mL}, \mathrm{~m}_{\text {cat }}=10 \mathrm{mg} \\
\mathrm{C}_{\mathrm{H} 2 \mathrm{O} 2}=0.05 \mathrm{~mol} \mathrm{~L}^{-1}, \mathrm{~T}=25^{\circ} \mathrm{C} \\
\mathrm{pH} 6 .\end{array}$ & Maximum removal observed was $93 \%$ & [164] \\
\hline $\begin{array}{l}\text { QN in Cyclohexane } \\
\left([\mathrm{N}]_{0}=500 \mathrm{ppm}\right)\end{array}$ & $\mathrm{FeMo} / \mathrm{CNT}$ & Aqueous $\mathrm{H}_{2} \mathrm{O}_{2}$ Phase & $\begin{array}{c}\mathrm{V}_{\text {fuel }}=5 \mathrm{~mL}, \mathrm{~m}_{\text {cat }}=20 \mathrm{mg}, \\
\mathrm{V}_{\mathrm{H} 2 \mathrm{O} 2}=1 \mathrm{~mL}\end{array}$ & $100 \% \mathrm{QN}$ oxidation in $30 \mathrm{~min}$ of reaction. & [146] \\
\hline
\end{tabular}

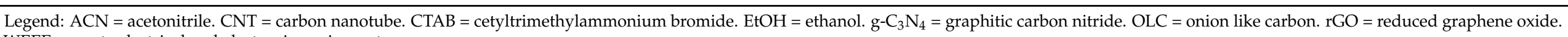
WEEE $=$ waste electrical and electronic equipment. 


\section{Final Considerations and Perspectives}

Carbon-based materials have proved to be interesting materials that can be used in ODS and ODN processes under different systems. The facility to tune their properties and combine with other materials to form hybrid materials makes them attractive when designing effective catalysts for desulfurization and denitrogenation. Especially in biphasic systems, their developed surface areas, which impact the dispersion of active phases and an increased adsorption capacity towards $S$ pollutants, have been pointed out as a key contribution of those materials, mainly for hybrid catalysts. Besides that, carbon materials were found to benefit ultrasonic cavitation, boosting reaction in ultrasoundassisted processes. Their usual hydrophobic nature increases the interaction with fuels and lipophilic pollutants, such as sulfur compounds, allowing them to act as phase transfer agents to extract these $S$ compounds. Finally, they were found to accelerate electron mobility, and in photocatalytic systems, they avoid electron-hole recombination. When considering carbon-based materials as catalysts on their own, their activity is mainly ascribed to the presence of oxygenated groups and defect sites. However, there is still some controversy on how each influences the desulfurization capacity. In amphiphilic materials, carbon-based materials were again used as catalysts on their own and in hybrid forms. Their main contribution comes from stabilizing PIC-like systems, where the material acts simultaneously as a catalyst and as an emulsifier.

However, a few points must be raised. (i) There are much more reports related to the application of carbon-based hybrid materials and much less related to carbonaceous structures as catalysts on their own. However, the results reported in this review point out that carbon materials have allowed similar removals to those observed with hybrid materials. Thus, there is still the opportunity to study carbon-based materials as catalysts on their own for desulfurization and denitrogenation. (ii) There is also a lack of reports testing carbon-based materials as catalysts on their own containing dopants other than oxygen. Nitrogen, phosphorus, and sulfur are all possible dopants that have been shown to increase catalytic activity in aqueous phase oxidation reactions [64,170-172]. (iii) Denitrogenation approaches are much less common, and there is still the opportunity to study denitrogenation reactions, mainly aiming at simultaneous high removals of $\mathrm{N}$ and S-containing compounds. (iv) There are very few works dealing with the use of catalysts prepared from renewable or waste sources. Environmental aspects related to the catalyst (metal leaching species and waste generation, among others), economic issues, or life cycle assessment (LCA) are not reported by any papers. (v) Most authors fail to explain the role of the carbonaceous structure in the process, or the advantages of using carbon-based materials, mainly when considering carbon-based composites for ODS and ODN purposes. Understanding the role of each component of the catalyst is critical to developing outstanding catalysts.

Author Contributions: Conceptualization, F.F.R., J.L.D.d.T., A.M.T.S., J.L.F. and H.T.G.; investigation, F.F.R.; writing—original draft preparation, F.F.R.; writing—review and editing, J.L.D.d.T., A.M.T.S., J.L.F. and H.T.G.; visualization, F.F.R. and J.L.D.d.T.; supervision, A.M.T.S., J.L.F. and H.T.G.; project administration, J.L.D.d.T. and H.T.G.; funding acquisition, J.L.D.d.T., A.M.T.S., J.L.F. and H.T.G.; All authors have read and agreed to the published version of the manuscript.

Funding: This work was supported by project "PLASTIC_TO_FUEL\&MAT-Upcycling Waste Plastics into Fuel and Carbon Nanomaterials" (PTDC/EQU-EQU/31439/2017), by Base-UIDB/50020/2020 and Programmatic-UIDP/50020/2020 funding of LSRE-LCM-funded by national funds through FCT/MCTES (PIDDAC), and CIMO (UIDB/00690/2020) through FEDER under Program PT2020. Fernanda F. Roman acknowledges the Foundation for Science and Technology (FCT) and the European Social Fund (FSE) for the individual research grant with reference SFRH/BD/143224/2019.

Conflicts of Interest: The authors declare no conflict of interest. 


\section{References}

1. Eurostat. Available online: https://ec.europa.eu/eurostat/databrowser/view/nrg_bal_c/default/table?lang=en (accessed on 13 July 2021).

2. Walters, C. Petroleum. In Kirk-Othmer Encyclopedia of Chemical Technology; John Wiley \& Sons, Inc.: Hoboken, NJ, USA, 2020; pp. 1-44. [CrossRef]

3. Marafi, A.; Albazzaz, H.; Rana, M.S. Hydroprocessing of heavy residual oil: Opportunities and challenges. Catal.Today 2019, 329, 125-134. [CrossRef]

4. Prado, G.H.C.; Rao, Y.; de Klerk, A. Nitrogen Removal from Oil: A Review. Energy Fuels 2017, 31, 14-36. [CrossRef]

5. Sikarwar, P.; Gosu, V.; Subbaramaiah, V. An overview of conventional and alternative technologies for the production of ultra-low-sulfur fuels. Rev. Chem. Eng. 2019, 35, 669-705. [CrossRef]

6. Ball, J.S.; Whisman, M.L.; Wenger, W.J. Nitrogen Content of Crude Petroleum. Ind. Eng. Chem. 1951, 43, 2577-2581. [CrossRef]

7. Ahmad, W. Sulfur in Petroleum: Petroleum Desulfurization Techniques. In Applying Nanotechnology to the Desulfurization Process in Petroleum Engineering; Saleh, T.A., Ed.; Engineering Science Reference: Hershey, PA, USA, 2016; pp. 1-50.

8. Song, C.; Ma, X. New design approaches to ultra-clean diesel fuels by deep desulfurization and deep dearomatization. Appl. Catal. B 2003, 41, 207-238. [CrossRef]

9. Romanow-Garcia, S.; Hoffman, H.L. Petroleum and Its Products. In Riegel's Handbook of Industrial Chemistry, 10th ed.; Kent, J.A., Ed.; Kluwer Academic/Plenum Publishers: New York, NY, USA, 2003; pp. 506-544.

10. Lloyd, A.C.; Cackette, T.A. Diesel engines: Environmental impact and control. J. Air Waste Manag. Assoc. 2001, 51, 809-847. [CrossRef]

11. Kampa, M.; Castanas, E. Human health effects of air pollution. Environ. Pollut. 2008, 151, 362-367. [CrossRef] [PubMed]

12. Pénard-Morand, C.; Annesi-Maesano, I. Air pollution: From sources of emissions to health effects. Breathe 2004, 1, 108-119. [CrossRef]

13. Cohen, A.J.; Pope III, C.A. Lung Cancer and Air Pollution. Environ. Health Perspect. 1995, 103, $219-224$.

14. Sunyer, J. The association of daily sulfur dioxide air pollution levels with hospital admissions for cardiovascular diseases in Europe (The Aphea-II study). Eur. Heart J. 2003, 24, 752-760. [CrossRef]

15. Wu, Y.; Li, R.; Cui, L.; Meng, Y.; Cheng, H.; Fu, H. The high-resolution estimation of sulfur dioxide $\left(\mathrm{SO}_{2}\right)$ concentration, health effect and monetary costs in Beijing. Chemosphere 2020, 241, 125031. [CrossRef]

16. Grennfelt, P.; Engleryd, A.; Forsius, M.; Hov, O.; Rodhe, H.; Cowling, E. Acid rain and air pollution: 50 years of progress in environmental science and policy. Ambio 2020, 49, 849-864. [CrossRef] [PubMed]

17. Burns, D.A.; Aherne, J.; Gay, D.A.; Lehmann, C.M.B. Acid rain and its environmental effects: Recent scientific advances. Atmos. Environ. 2016, 146, 1-4. [CrossRef]

18. Gandhi, H.S.; Shelef, M. Effects of sulphur on noble metal automotive catalysts. Appl. Catal. 1991, 77, 175-187. [CrossRef]

19. Council of the European Union. Official Journal of the European Union 140, Directive 2009/30/EC of the European Parliament and of the Council of 23 April 2009 Amending Directive 98/70/EC as Regards the Specification of Petrol, Diesel and Gas-Oil and Introducing a Mechanism to Monitor and Reduce Greenhouse Gas Emissions and Amending Council Directive 1999/32/EC as Regards the Specification of Fuel Used by Inland Waterway Vessels and Repealing Directive 93/12/EEC. 2009. Available online: https:/ / eur-lex.europa.eu/legal-content/EN/TXT/?uri=celex\%3A32009L0030 (accessed on 23 April 2021).

20. Control of Air Pollution from Motor Vehicles: Tier 3 Motor Vehicle Emission and Fuel Standards (Final Rule). Environmental Protection Agency. Federal Register Vol. 79, no 81, Monday, April 28th, 2014. Available online: https://www.govinfo.gov/ content/pkg/FR-2014-04-28/pdf/2014-06954.pdf (accessed on 23 April 2021).

21. EPA-420-B-16-005-Highway and Nonroad, Locomotive, and Marine (NRLM) Diesel Fuel Sulfur Standards. Office of Transportation and Air Quality, 2016. Available online: https:/ / nepis.epa.gov/Exe/ZyPDF.cgi?Dockey=P100O9ZH.pdf (accessed on 24 April 2021).

22. Miller, J.D.; Façanha, C. The State of Clean Transport Policy: A 2014 Synthesis of Vehicle and Fuel Policy Developments. International Council on Clean Transportation. Washington: International Council on Clean Transportation, 2014. Available online: https: / / theicct.org/publications / state-clean-transport-policy-2014-synthesis-vehicle-and-fuel-policy-developments (accessed on 10 June 2021).

23. Japan: Fuels: Diesel and Gasoline. Available online: https://www.transportpolicy.net/standard/japan-fuels-diesel-andgasoline/ (accessed on 24 April 2021).

24. China: Fuels: Diesel and Gasoline. Available online: https://www.transportpolicy.net/standard/china-fuels-diesel-andgasoline/ (accessed on 24 April 2021).

25. India: Fuels: Diesel and Gasoline. Available online: https://www.transportpolicy.net/standard/india-fuels-diesel-and-gasoline/ (accessed on 24 April 2021).

26. Russia: Fuels: Diesel and Gasoline. Available online: https://www.transportpolicy.net/standard/russia-fuels-diesel-andgasoline-2/ (accessed on 24 April 2021).

27. Fuel Quality Standards (Petrol) Determination 2019, Minister for the Environment. 2019. Available online: https://www. legislation.gov.au/Details/F2019L00455 (accessed on 24 April 2021). 
28. Regulation (EC) No. 715/2007 of the European Parliament and of the Council of 20 June 2007 on Type Approval of Motor Vehicles with Respect to Emissions from Light Passenger and Commercial Vehicles (Euro 5 and Euro 6) and on Access to Vehicle Repair and Maintenance Information. Available online: https:/ / eur-lex.europa.eu/legal-content/EN/ALL/?uri=celex\%3A32007R0715 (accessed on 24 April 2021).

29. Miller, J.; Jin, L. Global Progress Toward Soot-Free Diesel Vehicles in 2019. International Council on Clean Transportation, 2019. Available online: https: / theicct.org/publications/global-progress-toward-soot-free-diesel-vehicles-2019 (accessed on 17 May 2021).

30. Fahim, M.A.; Alsahhaf, T.A.; Elkilani, A. Hydroconversion. In Fundamentals of Petroleum Refining; Fahim, M.A., Alsahhaf, T.A., Elkilani, A., Eds.; Elsevier: Oxford, UK, 2010; pp. 153-198.

31. Speight, J.G. Hydrotreating and Desulfurization. In The Refinery of the Future; Gulf Professional Publishing: Burlington, MA, USA, 2011; pp. 237-273. [CrossRef]

32. Mochida, I.; Choi, K.-H. An Overview of Hydrodesulfurization and Hydrodenitrogenation. J. Jpn. Petrol. Inst. 2004, 47, 145-163. [CrossRef]

33. Bachrach, M.; Marks, T.J.; Notestein, J.M. Understanding the Hydrodenitrogenation of Heteroaromatics on a Molecular Level. ACS Catal. 2016, 6, 1455-1476. [CrossRef]

34. Rajendran, A.; Cui, T.-y.; Fan, H.-x.; Yang, Z.-f.; Feng, J.; Li, W.-y. A comprehensive review on oxidative desulfurization catalysts targeting clean energy and environment. J. Mater. Chem. A 2020, 8, 2246-2285. [CrossRef]

35. Brunet, S.; Mey, D.; Pérot, G.; Bouchy, C.; Diehl, F. On the hydrodesulfurization of FCC gasoline: A review. Appl. Catal. A 2005, 278, 143-172. [CrossRef]

36. Babich, I. Science and technology of novel processes for deep desulfurization of oil refinery streams: A review. Fuel 2003, 82, 607-631. [CrossRef]

37. Ibrahim, M.H.; Hayyan, M.; Hashim, M.A.; Hayyan, A. The role of ionic liquids in desulfurization of fuels: A review. Renew. Sustain. Energy Rev. 2017, 76, 1534-1549. [CrossRef]

38. Abro, R.; Abdeltawab, A.A.; Al-Deyab, S.S.; Yu, G.; Qazi, A.B.; Gao, S.; Chen, X. A review of extractive desulfurization of fuel oils using ionic liquids. RSC Adv. 2014, 4, 35302-35317. [CrossRef]

39. Majid, M.F.; Mohd Zaid, H.F.; Kait, C.F.; Jumbri, K.; Yuan, L.C.; Rajasuriyan, S. Futuristic advance and perspective of deep eutectic solvent for extractive desulfurization of fuel oil: A review. J. Mol. Liq. 2020, 306, 112870. [CrossRef]

40. Svinterikos, E.; Zuburtikudis, I.; Al-Marzouqi, M. Carbon Nanomaterials for the Adsorptive Desulfurization of Fuels. J. Nanotechnol. 2019, 2019, 2809867. [CrossRef]

41. Speight, J.G.; El-Gendy, N.S. Biocatalytic Desulfurization. In Introduction to Petroleum Biotechnology; Gulf Professional Publishing: Oxford, UK, 2018; pp. 165-227. [CrossRef]

42. Li, J.; Yang, Z.; Li, S.; Jin, Q.; Zhao, J. Review on oxidative desulfurization of fuel by supported heteropolyacid catalysts. J. Ind. Eng. Chem. 2020, 82, 1-16. [CrossRef]

43. Hossain, M.; Park, H.; Choi, H. A Comprehensive Review on Catalytic Oxidative Desulfurization of Liquid Fuel Oil. Catalyst 2019, 9, 229. [CrossRef]

44. Haghighi, M.; Gooneh-Farahani, S. Insights to the oxidative desulfurization process of fossil fuels over organic and inorganic heterogeneous catalysts: Advantages and issues. Environ. Sci. Pollut. Res. Int. 2020, 27, 39923-39945. [CrossRef] [PubMed]

45. Otsuki, S.; Nonaka, T.; Takashima, N.; Qian, W.; Ishihara, A.; Imai, T.; Kabe, T. Oxidative Desulfurization of Light Gas Oil and Vacuum Gas Oil by Oxidation and Solvent Extraction. Energy Fuels 2000, 14, 1232-1239. [CrossRef]

46. Ogunlaja, A.S.; Abdul-quadir, M.S.; Kleyi, P.E.; Ferg, E.E.; Watts, P.; Tshentu, Z.R. Towards oxidative denitrogenation of fuel oils: Vanadium oxide-catalysed oxidation of quinoline and adsorptive removal of quinoline-N-oxide using 2,6-pyridinepolybenzimidazole nanofibers. Arab. J. Chem. 2019, 12, 198-214. [CrossRef]

47. Nicolaescu, A.R.; Wiest, O.; Kamat, P.V. Mechanistic pathways of the hydroxyl radical reactions of quinoline. 1. Identification, distribution, and yields of hydroxylated products. J. Phys. Chem. A 2005, 109, 2822-2828. [CrossRef]

48. Weeranoppanant, N. Enabling tools for continuous-flow biphasic liquid-liquid reaction. Reac. Chem. Eng. 2019, 4, 235-243. [CrossRef]

49. Xue, N.; Zhang, G.; Zhang, X.; Yang, H. A reinforced Pickering emulsion for cascade reactions. Chem Comm 2018, 54, 13014-13017. [CrossRef] [PubMed]

50. Pera-Titus, M.; Leclercq, L.; Clacens, J.M.; De Campo, F.; Nardello-Rataj, V. Pickering interfacial catalysis for biphasic systems: From emulsion design to green reactions. Angew. Chem. Int. Ed. 2015, 54, 2006-2021. [CrossRef] [PubMed]

51. Jiang, H.; Sheng, Y.; Ngai, T. Pickering emulsions: Versatility of colloidal particles and recent applications. Curr. Opin. Colloid Interface Sci. 2020, 49, 1-15. [CrossRef]

52. Sjoo, M.; Rayner, M.; Wahlgren, M. Particle-stabilized Emulsions. In Engineering Aspects of Food Emulsification and Homogenization; Rayner, M., Dejmek, P., Eds.; CRC Press: Boca Raton, FL, USA, 2015; pp. 101-122.

53. Chevalier, Y.; Bolzinger, M.-A. Emulsions stabilized with solid nanoparticles: Pickering emulsions. Colloids Surf. A Physicochem. Eng. Asp. 2013, 439, 23-34. [CrossRef]

54. Briggs, N.; Raman, A.K.Y.; Barrett, L.; Brown, C.; Li, B.; Leavitt, D.; Aichele, C.P.; Crossley, S. Stable pickering emulsions using multi-walled carbon nanotubes of varying wettability. Colloids Surf. A Physicochem. Eng. Asp. 2018, 537, 227-235. [CrossRef] 
55. Briggs, N.M.; Weston, J.S.; Li, B.; Venkataramani, D.; Aichele, C.P.; Harwell, J.H.; Crossley, S.P. Multiwalled Carbon Nanotubes at the Interface of Pickering Emulsions. Langmuir 2015, 31, 13077-13084. [CrossRef]

56. Wang, Z.; Wang, Y. Tuning Amphiphilicity of Particles for Controllable Pickering Emulsion. Materials 2016, 9, 903. [CrossRef]

57. Bhadra, B.N.; Jhung, S.H. Oxidative desulfurization and denitrogenation of fuels using metal-organic framework-based/-derived catalysts. Appl. Catal. B 2019, 259, 118021. [CrossRef]

58. Ribeiro, R.S.; Silva, A.M.T.; Figueiredo, J.L.; Faria, J.L.; Gomes, H.T. The influence of structure and surface chemistry of carbon materials on the decomposition of hydrogen peroxide. Carbon 2013, 62, 97-108. [CrossRef]

59. Fang, G.; Gao, J.; Liu, C.; Dionysiou, D.D.; Wang, Y.; Zhou, D. Key role of persistent free radicals in hydrogen peroxide activation by biochar: Implications to organic contaminant degradation. Environ. Sci. Technol. 2014, 48, 1902-1910. [CrossRef]

60. Vega, E.; Valdés, H. New evidence of the effect of the chemical structure of activated carbon on the activity to promote radical generation in an advanced oxidation process using hydrogen peroxide. Micropor. Mesopor. Mat. 2018, 259, 1-8. [CrossRef]

61. Martin-Martinez, M.; Álvarez-Torrellas, S.; García, J.; Silva, A.M.T.; Faria, J.L.; Gomes, H.T. Exploring the activity of chemicalactivated carbons synthesized from peach stones as metal-free catalysts for wet peroxide oxidation. Catal. Today 2018, 313, 20-25. [CrossRef]

62. Martin-Martinez, M.; Machado, B.F.; Serp, P.; Morales-Torres, S.; Silva, A.M.T.; Figueiredo, J.L.; Faria, J.L.; Gomes, H.T. Carbon nanotubes as catalysts for wet peroxide oxidation: The effect of surface chemistry. Catal. Today 2020, 357, 332-340. [CrossRef]

63. Ribeiro, R.S.; Silva, A.M.T.; Figueiredo, J.L.; Faria, J.L.; Gomes, H.T. Catalytic wet peroxide oxidation: A route towards the application of hybrid magnetic carbon nanocomposites for the degradation of organic pollutants. A review. Appl. Catal. B. 2016, 187, 428-460. [CrossRef]

64. Duan, X.; Sun, H.; Wang, S. Metal-Free Carbocatalysis in Advanced Oxidation Reactions. Acc. Chem. Res. 2018, 51, 678-687. [CrossRef]

65. Xiao, P.-f.; An, L.; Wu, D.-d. The use of carbon materials in persulfate-based advanced oxidation processes: A review. New Carbon Mater. 2020, 35, 667-683. [CrossRef]

66. He, X.; Zheng, N.; Hu, R.; Hu, Z.; Yu, J.C. Hydrothermal and Pyrolytic Conversion of Biomasses into Catalysts for Advanced Oxidation Treatments. Adv. Funct. Mater. 2020, 31, 2006505. [CrossRef]

67. Rocha, R.P.; Pereira, M.F.R.; Figueiredo, J.L. Metal-free carbon materials as catalysts for wet air oxidation. Catal. Today 2020, 356, 189-196. [CrossRef]

68. Vieira, O.; Ribeiro, R.S.; Diaz de Tuesta, J.L.; Gomes, H.T.; Silva, A.M.T. A systematic literature review on the conversion of plastic wastes into valuable 2D graphene-based materials. Chem. Eng. J. 2021, 428, 131399. [CrossRef]

69. González-García, P. Activated carbon from lignocellulosics precursors: A review of the synthesis methods, characterization techniques and applications. Renew. Sustain. Energy Rev. 2018, 82, 1393-1414. [CrossRef]

70. Vivekanandhan, S.; Schreiber, M.; Muthuramkumar, S.; Misra, M.; Mohanty, A.K. Carbon nanotubes from renewable feedstocks: A move toward sustainable nanofabrication. J. Appl. Polym. Sci. 2017, 134, 44255. [CrossRef]

71. Kumar, M.; Ando, Y. Chemical vapor deposition of carbon nanotubes: A review on growth mechanism and mass production. J. Nanosci. Nanotechnol. 2020, 10, 3739-3758. [CrossRef]

72. Das, R.; Shahnavaz, Z.; Ali, M.E.; Islam, M.M.; Abd Hamid, S.B. Can We Optimize Arc Discharge and Laser Ablation for Well-Controlled Carbon Nanotube Synthesis? Nanoscale Res. Lett. 2016, 11, 510. [CrossRef] [PubMed]

73. Edwards, R.S.; Coleman, K.S. Graphene synthesis: Relationship to applications. Nanoscale 2013, 5, 38-51. [CrossRef] [PubMed]

74. Kong, L.; Wang, J.; Ma, F.; Sun, M.; Quan, J. Graphitic carbon nitride nanostructures: Catalysis. Appl. Mater. Today 2019, 16, 388-424. [CrossRef]

75. Rono, N.; Kibet, J.K.; Martincigh, B.S.; Nyamori, V.O. A review of the current status of graphitic carbon nitride. Crit. Rev. Solid State Mater. Sci. 2020, 46, 189-217. [CrossRef]

76. Rafiee, E.; Khodayari, M. Synthesis and characterization of $\mathrm{PMoV} / \mathrm{Fe}_{3} \mathrm{O}_{4} / \mathrm{g}-\mathrm{C}_{3} \mathrm{~N}_{4}$ from melamine: An industrial green nanocatalyst for deep oxidative desulfurization. Chin. J. Catal. 2017, 38, 458-468. [CrossRef]

77. Meman, N.M.; Zarenezhad, B.; Rashidi, A.; Hajjar, Z.; Esmaeili, E. Application of palladium supported on functionalized MWNTs for oxidative desulfurization of naphtha. J. Ind. Eng. Chem. 2015, 22, 179-184. [CrossRef]

78. Zhu, Y.; Zhu, M.; Kang, L.; Yu, F.; Dai, B. Phosphotungstic Acid Supported on Mesoporous Graphitic Carbon Nitride as Catalyst for Oxidative Desulfurization of Fuel. Ind. Eng. Chem. Res. 2015, 54, 2040-2047. [CrossRef]

79. Meman, N.M.; Pourkhalil, M.; Rashidi, A.; ZareNezhad, B. Synthesis, characterization and operation of a functionalized multiwalled CNT supported MnOx nanocatalyst for deep oxidative desulfurization of sour petroleum fractions. J. Ind. Eng. Chem. 2014, 20, 4054-4058. [CrossRef]

80. Ugal, J.R.; Jima'a, R.B.; Al-Jubori, W.M.K.; Abbas, B.F.; Al-Jubori, N.M. Oxidative Desulfurization of Hydrotreated Gas Oil using $\mathrm{Fe}_{2} \mathrm{O}_{3}$ and Pd Loaded over Activated Carbon as Catalysts. Orient. J. Chem. 2018, 34, 1091-1097. [CrossRef]

81. Alwan, H.H.; Ali, A.A.; Makki, H.F. Optimization of Oxidative Desulfurization Reaction with $\mathrm{Fe}_{2} \mathrm{O}_{3}$ Catalyst Supported on Graphene Using Box-Behnken Experimental Method. Bull. Chem. React. Eng. Catal. 2020, 15, 175-185. [CrossRef]

82. Rafiee, E.; Joshaghani, M.; Ghaderi-Shekhi Abadi, P. Oxidative desulfurization of diesel by potato based-carbon as green support for $\mathrm{H}_{5} \mathrm{PMo}_{10} \mathrm{~V}_{2} \mathrm{O}_{40}$ : Efficient composite nanorod catalyst. J. Saudi Chem. Soc. 2017, 21, 599-609. [CrossRef]

83. Huang, P.; Liu, A.; Kang, L.; Dai, B.; Zhu, M.; Zhang, J. Heteropolyacid Supported on Nitrogen-doped Onion-Like Carbon as Catalyst for Oxidative Desulfurization. ChemistrySelect 2017, 2, 4010-4015. [CrossRef] 
84. Rafiee, E.; Shahbazirad, A.; Khodayari, M. Preparation and characterization of nanocomposite of graphitic carbon nitride and $\mathrm{TiO}_{2}$ as a porous support for nano catalyst for desulfurization process. J. Saudi Chem. Soc. 2017, 21, 943-953. [CrossRef]

85. Abdelrahman, A.A.; Betiha, M.A.; Rabie, A.M.; Ahmed, H.S.; Elshahat, M.F. Removal of refractory Organo-sulfur compounds using an efficient and recyclable $\left\{\mathrm{Mo}_{132}\right\}$ nanoball supported graphene oxide. J. Mol. Liq. 2018, 252, 121-132. [CrossRef]

86. Wang, C.; Li, A.; Xu, J.; Wen, J.; Zhang, H.; Zhang, L. Preparation of $\mathrm{WO}_{3} / \mathrm{CNT}$ catalysts in presence of ionic liquid [C $\left.16 \mathrm{mim}\right] \mathrm{Cl}$ and catalytic efficiency in oxidative desulfurization. J. Chem. Technol. Biotechnol. 2019, 94, 3403-3412. [CrossRef]

87. Gao, Y.; Cheng, L.; Gao, R.; Hu, G.; Zhao, J. Deep desulfurization of fuels using supported ionic liquid-polyoxometalate hybrid as catalyst: A comparison of different types of ionic liquids. J. Hazard. Mater. 2021, 401, 123267. [CrossRef] [PubMed]

88. Zhuang, L.; Li, Q.; Chen, S.; Hou, X.; Lin, J. In-situ preparation of porous carbon-supported molybdenum dioxide and its performance in the oxidative desulfurization of thiophene. J. Mater. Sci. 2014, 49, 5606-5616. [CrossRef]

89. Gao, Y.; Liu, Z.; Gao, R.; Hu, G.; Zhao, J. Support ionic liquid-heteropolyacid hybrid on mesoporous carbon aerogel with a high surface area for highly efficient desulfurization under mild conditions. Micropor. Mesopor. Mat. 2020, 305, 110392. [CrossRef]

90. Rongxiang, Z.; Xiuping, L.; Jianxun, S.; Weiwei, S.; Xiaohan, G. The preparation of $\mathrm{WO}_{3} / \mathrm{C}$ composite and its application in oxidative desulfurization of fuel. China Pet. Process. Petrochem. Technol. 2017, 19, 65-73.

91. Xiao, J.; Wu, L.; Wu, Y.; Liu, B.; Dai, L.; Li, Z.; Xia, Q.; Xi, H. Effect of gasoline composition on oxidative desulfurization using a phosphotungstic acid/activated carbon catalyst with hydrogen peroxide. Appl. Energy 2014, 113, 78-85. [CrossRef]

92. Bhadra, B.N.; Song, J.Y.; Khan, N.A.; Jhung, S.H. $\mathrm{TiO}_{2}$-Containing Carbon Derived from a Metal-Organic Framework Composite: A Highly Active Catalyst for Oxidative Desulfurization. ACS Appl. Mat. Interfaces 2017, 9, 31192-31202. [CrossRef]

93. Khan, N.A.; Bhadra, B.N.; Park, S.W.; Han, Y.S.; Jhung, S.H. Tungsten Nitride, Well-Dispersed on Porous Carbon: Remarkable Catalyst, Produced without Addition of Ammonia, for the Oxidative Desulfurization of Liquid Fuel. Small 2020, 16, e1901564. [CrossRef]

94. Do Prado, N.T.; Heitmann, A.P.; Mansur, H.S.; Mansur, A.A.; Oliveira, L.C.A.; de Castro, C.S. PET-modified red mud as catalysts for oxidative desulfurization reactions. J. Environ. Sci. 2017, 57, 312-320. [CrossRef] [PubMed]

95. Wang, C.; Miao, Q.; Huang, X.; Li, J.; Duan, Y.; Yan, L.; Jiang, Y.; Lu, S. Fabrication of various morphological forms of a g- $\mathrm{C}_{3} \mathrm{~N}_{4}$-supported $\mathrm{MoO}_{3}$ catalyst for the oxidative desulfurization of dibenzothiophene. New J. Chem. 2020, 44, 18745-18755 [CrossRef]

96. Zhao, R.; Li, X.; Su, J.; Gao, X. Preparation of $\mathrm{WO}_{3} / \mathrm{g}-\mathrm{C}_{3} \mathrm{~N}_{4}$ composites and their application in oxidative desulfurization. Appl. Surf. Sci. 2017, 392, 810-816. [CrossRef]

97. Zhu, J.; Wu, P.; Chen, L.; He, J.; Wu, Y.; Wang, C.; Chao, Y.; Lu, L.; He, M.; Zhu, W.; et al. 3D-printing of integrated spheres as a superior support of phosphotungstic acid for deep oxidative desulfurization of fuel. J. Energy Chem. 2020, 45, 91-97. [CrossRef]

98. Hou, L.-p.; Zhao, R.-X.; Li, X.-p.; Gao, X.-h. Preparation of $\mathrm{MoO}_{2} /$ g- $\mathrm{C}_{3} \mathrm{~N}_{4}$ composites with a high surface area and its application in deep desulfurization from model oil. Appl. Surf. Sci. 2018, 434, 1200-1209. [CrossRef]

99. Ye, J.; Wen, J.; Zhao, D.; Zhang, P.; Li, A.; Zhang, L.; Zhang, H.; Wu, M. Macroporous 3D carbon-nitrogen $(\mathrm{CN})$ confined MoO catalyst for enhanced oxidative desulfurization of dibenzothiophene. Chin. Chem. Lett. 2020, 31, 2819-2824. [CrossRef]

100. Ghubayra, R.; Nuttall, C.; Hodgkiss, S.; Craven, M.; Kozhevnikova, E.F.; Kozhevnikov, I.V. Oxidative desulfurization of model diesel fuel catalyzed by carbon-supported heteropoly acids. Appl. Catal. B 2019, 253, 309-316. [CrossRef]

101. Wang, R.; Yu, F.; Zhang, G.; Zhao, H. Performance evaluation of the carbon nanotubes supported $\mathrm{Cs}_{2.5} \mathrm{H}_{0.5} \mathrm{PW}_{12} \mathrm{O}_{40}$ as efficient and recoverable catalyst for the oxidative removal of dibenzothiophene. Catal. Today 2010, 150, 37-41. [CrossRef]

102. Xing, P.; Zhao, R.; Li, X.; Gao, X. Preparation of $\mathrm{CoWO}_{4} / g-\mathrm{C}_{3} \mathrm{~N}_{4}$ and its Ultra-Deep Desulfurization Property. Aust. J. Chem. 2017, 70, 271. [CrossRef]

103. Quyen, N.D.V.; Tuyen, T.N.; Khieu, D.Q.; Hai, H.V.M.; Tin, D.X.; Itatani, K. Oxidation of dibenzothiophene using the heterogeneous catalyst of tungsten-based carbon nanotubes. Green Process. Synth. 2019, 8, 68-77. [CrossRef]

104. Wang, Q.; Wang, S.; Yu, H. Oxidative desulphurization of model fuel by in situ produced hydrogen peroxide on palladium/active carbon. Can. J. Chem. Eng. 2017, 95, 136-141. [CrossRef]

105. Yu, G.X.; Zhou, R.X.; Li, J.B.; Zhou, X.L.; Li, C.L.; Chen, L.F.; Wang, J.A. Oxidative Removal of Dibenzothiophene by $\mathrm{H}_{2} \mathrm{O}_{2}$ over Activated Carbon-Supported Phosphotungstic Acid Catalysts. Adv. Mat. Res. 2010, 132, 126-132. [CrossRef]

106. Kermani, A.M.; Ahmadpour, A.; Bastami, T.R.; Ghahramaninezhad, M. Deep oxidative desulfurization of dibenzothiophene with $\{$ Mo-132\} nanoballs supported on activated carbon as an efficient catalyst at room temperature. New J. Chem. 2018, 42, 12188-12197. [CrossRef]

107. Liu, L.; Zhang, Y.; Tan, W. Ultrasound-assisted oxidation of dibenzothiophene with phosphotungstic acid supported on activated carbon. Ultrason. Sonochem. 2014, 21, 970-974. [CrossRef]

108. Liu, L.; Zhang, Y.; Tan, W. Synthesis and characterization of phosphotungstic acid/activated carbon as a novel ultrasound oxidative desulfurization catalyst. Front. Chem. Sci. Eng. 2013, 7, 422-427. [CrossRef]

109. Piccinino, D.; Abdalghani, I.; Botta, G.; Crucianelli, M.; Passacantando, M.; Di Vacri, M.L.; Saladino, R. Preparation of wrapped carbon nanotubes poly(4-vinylpyridine)/MTO based heterogeneous catalysts for the oxidative desulfurization (ODS) of model and synthetic diesel fuel. Appl. Catal. B 2017, 200, 392-401. [CrossRef]

110. Dini, Z.; Afsharpour, M.; Tabar-Heydar, K. UV-assisted functionalization of carbon nanotube for synthesis of efficient desulfurization catalysts $\left(\mathrm{NH}_{2} / \mathrm{COOH}\right)-\mathrm{MWNT} / \mathrm{MoO}_{3}$. Diam. Relat. Mat. 2019, 91, 237-246. [CrossRef] 
111. Afsharpour, M.; Dini, Z. One-pot functionalization of carbon nanotubes by $\mathrm{WO}_{3} / \mathrm{MoO}_{3}$ nanoparticles as oxidative desulfurization catalysts. Fuller. Nanotub. Carbon Nanostructures 2018, 27, 198-205. [CrossRef]

112. Bhadra, B.N.; Khan, N.A.; Jhung, S.H. Co supported on N-doped carbon, derived from bimetallic azolate framework-6: A highly effective oxidative desulfurization catalyst. J. Mat. Chem. A 2019, 7, 17823-17833. [CrossRef]

113. Liao, X.; Huang, Y.; Zhou, Y.; Liu, H.; Cai, Y.; Lu, S.; Yao, Y. Homogeneously dispersed HPW/graphene for high efficient catalytic oxidative desulfurization prepared by electrochemical deposition. Appl. Surf. Sci. 2019, 484, 917-924. [CrossRef]

114. Ma, R.; Guo, J.; Wang, D.; He, M.; Xun, S.; Gu, J.; Zhu, W.; Li, H. Preparation of highly dispersed $\mathrm{WO}_{3} /$ few layer g-C $\mathrm{C}_{3} \mathrm{~N}_{4}$ and its enhancement of catalytic oxidative desulfurization activity. Colloids Surf. A Physicochem. Eng. Asp. 2019, 572, 250-258. [CrossRef]

115. Chen, K.; Zhang, X.-M.; Yang, X.-F.; Jiao, M.-G.; Zhou, Z.; Zhang, M.-H.; Wang, D.-H.; Bu, X.-H. Electronic structure of heterojunction $\mathrm{MoO}_{2} / \mathrm{g}-\mathrm{C}_{3} \mathrm{~N}_{4}$ catalyst for oxidative desulfurization. Appl. Catal. B 2018, 238, 263-273. [CrossRef]

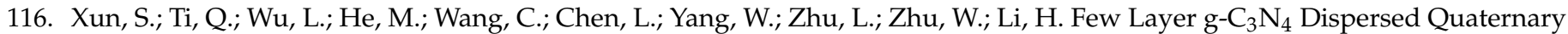
Phosphonium Ionic Liquid for Highly Efficient Catalytic Oxidative Desulfurization of Fuel. Energy Fuels 2020, 34, 12379-12387. [CrossRef]

117. Gu, J.; Liu, M.; Xun, S.; He, M.; Wu, L.; Zhu, L.; Wu, X.; Zhu, W.; Li, H. Lipophilic decavanadate supported by three-dimensional porous carbon nitride catalyst for aerobic oxidative desulfurization. Mol. Catal. 2020, 483, 110709. [CrossRef]

118. Chen, S.; Lu, W.; Yao, Y.; Chen, H.; Chen, W. Oxidative desulfurization of dibenzothiophene with molecular oxygen catalyzed by carbon fiber-supported iron phthalocyanine. React. Kinet. Mech. Catal. 2013, 111, 535-547. [CrossRef]

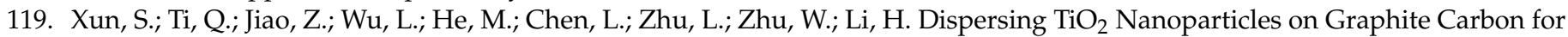
an Enhanced Catalytic Oxidative Desulfurization Performance. Ind. Eng. Chem. Res. 2020, 59, 18471-18479. [CrossRef]

120. Gao, Y.; Lv, Z.; Gao, R.; Hu, G.; Zhao, J. Dawson type polyoxometalate based-poly ionic liquid supported on different carbon materials for high-efficiency oxidative desulfurization with molecular oxygen as the oxidant. New J. Chem. 2020, 44, 20358-20366. [CrossRef]

121. Chen, L.; Ren, J.-T.; Yuan, Z.-Y. Atomic heterojunction-induced electron interaction in P-doped g- $\mathrm{C}_{3} \mathrm{~N}_{4}$ nanosheets supported V-based nanocomposites for enhanced oxidative desulfurization. Chem. Eng. J. 2020, 387, 124164. [CrossRef]

122. Zou, J.; Lin, Y.; Wu, S.; Zhong, Y.; Yang, C. Molybdenum Dioxide Nanoparticles Anchored on Nitrogen-Doped Carbon Nanotubes as Oxidative Desulfurization Catalysts: Role of Electron Transfer in Activity and Reusability. Adv. Funct. Mat. 2021, 31, 2100442. [CrossRef]

123. Wang, C.; Zhu, W.; Xu, Y.; Xu, H.; Zhang, M.; Chao, Y.; Yin, S.; Li, H.; Wang, J. Preparation of TiO 2 /g-C $\mathrm{C}_{3} \mathrm{~N}_{4}$ composites and their application in photocatalytic oxidative desulfurization. Ceram. Int. 2014, 40, 11627-11635. [CrossRef]

124. Li, X.; Zhu, W.; Lu, X.; Zuo, S.; Yao, C.; Ni, C. Integrated nanostructures of $\mathrm{CeO}_{2} /$ attapulgite/g-C $\mathrm{C}_{3} \mathrm{~N}_{4}$ as efficient catalyst for photocatalytic desulfurization: Mechanism, kinetics and influencing factors. Chem. Eng. J. 2017, 326, 87-98. [CrossRef]

125. Ma, S.; Li, X.; Lu, X.; Zuo, S.; Li, Z.; Yao, C. Carbon quantum dots/attapulgite nanocomposites with enhanced photocatalytic performance for desulfurization. J. Mater. Sci.: Mater. Electron. 2017, 29, 2709-2715. [CrossRef]

126. Zhang, G.; Ren, J.; Zhao, W.; Tian, M.; Chen, W. Photocatalytic desulfurization of thiophene base on molecular oxygen and zinc phthalocyanine/g- $\mathrm{C}_{3} \mathrm{~N}_{4}$. Res. Chem. Intermed. 2018, 44, 5547-5557. [CrossRef]

127. Vu, T.H.T.; Nguyen, T.T.T.; Nguyen, P.H.T.; Do, M.H.; Au, H.T.; Nguyen, T.B.; Nguyen, D.L.; Park, J.S. Fabrication of photocatalytic composite of multi-walled carbon nanotubes $/ \mathrm{TiO}_{2}$ and its application for desulfurization of diesel. Mater. Res. Bull. 2012, 47, 308-314. [CrossRef]

128. Jiang, W.; Zheng, D.; Xun, S.; Qin, Y.; Lu, Q.; Zhu, W.; Li, H. Polyoxometalate-based ionic liquid supported on graphite carbon induced solvent-free ultra-deep oxidative desulfurization of model fuels. Fuel 2017, 190, 1-9. [CrossRef]

129. Astle, M.A.; Rance, G.A.; Loughlin, H.J.; Peters, T.D.; Khlobystov, A.N. Molybdenum Dioxide in Carbon Nanoreactors as a Catalytic Nanosponge for the Efficient Desulfurization of Liquid Fuels. Adv. Funct. Mat. 2019, 29, 1808092. [CrossRef]

130. Kampouraki, Z.C.; Giannakoudakis, D.A.; Triantafyllidis, K.S.; Deliyanni, E.A. Catalytic oxidative desulfurization of a 4,6-DMDBT containing model fuel by metal-free activated carbons: The key role of surface chemistry. Green Chem. 2019, 21, 6685-6698. [CrossRef]

131. He, J.; Wu, P.; Lu, L.; Sun, H.; Jia, Q.; Hua, M.; He, M.; Xu, C.; Zhu, W.; Li, H. Synthesis of N,O-Doped Porous Graphene from Petroleum Coke for Deep Oxidative Desulfurization of Fuel. Energy Fuels 2019, 33, 8302-8311. [CrossRef]

132. Gonzalez, L.A.; Kracke, P.; Green, W.H.; Tester, J.W.; Shafer, L.M.; Timko, M.T. Oxidative Desulfurization of Middle-Distillate Fuels Using Activated Carbon and Power Ultrasound. Energy Fuels 2012, 26, 5164-5176. [CrossRef]

133. Haw, K.-G.; Bakar, W.A.W.A.; Ali, R.; Chong, J.-F.; Kadir, A.A.A. Catalytic oxidative desulfurization of diesel utilizing hydrogen peroxide and functionalized-activated carbon in a biphasic diesel-acetonitrile system. Fuel Process. Technol. 2010, 91, 1105-1112. [CrossRef]

134. Gu, Q.; Ding, Y.; Liu, Z.; Lin, Y.; Schlögl, R.; Heumann, S.; Su, D. Probing the intrinsic catalytic activity of carbon nanotubes for the metal-free oxidation of aromatic thiophene compounds in ionic liquids. J. Energy Chem. 2019, 32, 131-137. [CrossRef]

135. Gu, Q.; Wen, G.; Ding, Y.; Wu, K.-H.; Chen, C.; Su, D. Reduced graphene oxide: A metal-free catalyst for aerobic oxidative desulfurization. Green Chem. 2017, 19, 1175-1181. [CrossRef]

136. Zhang, W.; Zhang, H.; Xiao, J.; Zhao, Z.; Yu, M.; Li, Z. Carbon nanotube catalysts for oxidative desulfurization of a model diesel fuel using molecular oxygen. Green Chem. 2014, 16, 211-220. [CrossRef] 
137. Zeng, X.; Xiao, X.; Li, Y.; Chen, J.; Wang, H. Deep desulfurization of liquid fuels with molecular oxygen through graphene photocatalytic oxidation. Appl. Catal. B 2017, 209, 98-109. [CrossRef]

138. Timko, M.T.; Wang, J.A.; Burgess, J.; Kracke, P.; Gonzalez, L.; Jaye, C.; Fischer, D.A. Roles of surface chemistry and structural defects of activated carbons in the oxidative desulfurization of benzothiophenes. Fuel 2016, 163, 223-231. [CrossRef]

139. Abdi, G.; Ashokkumar, M.; Alizadeh, A. Ultrasound-assisted oxidative-adsorptive desulfurization using highly acidic graphene oxide as a catalyst-adsorbent. Fuel 2017, 210, 639-645. [CrossRef]

140. Liu, H.; Li, Z.; Dong, J.; Liu, D.; Liu, C.; Chi, Y.; Hu, C. Polyoxometalates encapsulated into hollow double-shelled nanospheres as amphiphilic nanoreactors for an effective oxidative desulfurization. Nanoscale 2020, 12, 16586-16595. [CrossRef]

141. Yu, Z.; Huang, X.; Xun, S.; He, M.; Zhu, L.; Wu, L.; Yuan, M.; Zhu, W.; Li, H. Synthesis of carbon nitride supported amphiphilic phosphotungstic acid based ionic liquid for deep oxidative desulfurization of fuels. J. Mol. Liq. 2020, 308, 113059. [CrossRef]

142. Li, X.; Yang, X.; Zhou, F.; Zhang, J.; Yang, H.; Wang, Y.; Zhao, Y.; Yuan, X.; Ju, J.; Hu, S. Construction of novel amphiphilic $[\mathrm{Bmin}]_{3} \mathrm{PMo}_{12} \mathrm{O}_{40} / \mathrm{g}-\mathrm{C}_{3} \mathrm{~N}_{4}$ heterojunction catalyst with outstanding photocatalytic oxidative desulfurization performance under visible light. J. Taiwan Inst. Chem. Eng. 2019, 100, 210-219. [CrossRef]

143. Mambrini, R.V.; Maia, C.Z.; Ardisson, J.D.; de Souza, P.P.; Moura, F.C.C. Fe/C and FeMo/C hybrid materials for the biphasic oxidation of fuel contaminants. New J. Chem. 2017, 41, 142-150. [CrossRef]

144. Oliveira, A.A.S.; Christofani, T.; Teixeira, I.F.; Ardisson, J.D.; Moura, F.C.C. Magnetic amphiphilic nanocomposites based on silica-carbon for sulphur contaminant oxidation. New J. Chem. 2015, 39, 5445-5452. [CrossRef]

145. Oliveira, A.A.S.; Teixeira, I.F.; Christofani, T.; Tristão, J.C.; Guimarães, I.R.; Moura, F.C.C. Biphasic oxidation reactions promoted by amphiphilic catalysts based on red mud residue. Appl. Catal. B 2014, 144, 144-151. [CrossRef]

146. Teixeira, I.F.; da Silva Oliveira, A.A.; Christofani, T.; Moura, F.C.C. Biphasic oxidation promoted by magnetic amphiphilic nanocomposites undergoing a reversible emulsion process. J. Mat. Chem. A 2013, 1, 10203-10208. [CrossRef]

147. Dou, S.-Y.; Wang, R. The C-Si Janus nanoparticles with supported phosphotungstic active component for Pickering emulsion desulfurization of fuel oil without stirring. Chem. Eng. J. 2019, 369, 64-76. [CrossRef]

148. Hasannia, S.; Kazemeini, M.; Rashidi, A.; Seif, A. The oxidative desulfurization process performed upon a model fuel utilizing modified molybdenum based nanocatalysts: Experimental and density functional theory investigations under optimally prepared and operated conditions. Appl. Surf. Sci. 2020, 527, 146798. [CrossRef]

149. Abdullah, W.N.W.; Bakar, W.A.W.A.; Abdullah, N.H.; Mokhtar, W.N.A.W.; Rosid, S.J.M.; Shukri, N.M. Effect of activated carbon supported Ce/Fe based catalyst for catalytic oxidative desulfurization of Malaysian diesel fuel. AIP Conf. Proc. 2019, $2068,020075$. [CrossRef]

150. Dizaji, A.K.; Mokhtarani, B.; Mortaheb, H.R. Deep and fast oxidative desulfurization of fuels using graphene oxide-based phosphotungstic acid catalysts. Fuel 2019, 236, 717-729. [CrossRef]

151. Dizaji, A.K.; Mortaheb, H.R.; Mokhtarani, B. Complete oxidative desulfurization using graphene oxide-based phosphomolybdic acid catalyst: Process optimization by two phase mass balance approach. Chem. Eng. J. 2018, 335, 362-372. [CrossRef]

152. Tamborrino, V.; Costamagna, G.; Bartoli, M.; Rovere, M.; Jagdale, P.; Lavagna, L.; Ginepro, M.; Tagliaferro, A. Catalytic oxidative desulphurization of pyrolytic oils to fuels over different waste derived carbon-based catalysts. Fuel 2021, 296, 120693. [CrossRef]

153. Gao, Y.; Gao, R.; Zhang, G.; Zheng, Y.; Zhao, J. Oxidative desulfurization of model fuel in the presence of molecular oxygen over polyoxometalate based catalysts supported on carbon nanotubes. Fuel 2018, 224, 261-270. [CrossRef]

154. Gao, Y.; Lv, Z.; Gao, R.; Zhang, G.; Zheng, Y.; Zhao, J. Oxidative desulfurization process of model fuel under molecular oxygen by polyoxometalate loaded in hybrid material CNTs@MOF-199 as catalyst. J. Hazard. Mat. 2018, 359, 258-265. [CrossRef] [PubMed]

155. Jiang, W.; Xiao, J.; Dong, L.; Wang, C.; Li, H.; Luo, Y.; Zhu, W.; Li, H. Polyoxometalate-Based Poly(ionic liquid) as a Precursor for Superhydrophobic Magnetic Carbon Composite Catalysts toward Aerobic Oxidative Desulfurization. ACS Sustain. Chem. Eng. 2019, 7, 15755-15761. [CrossRef]

156. Wang, Y.; Zhang, G.; Guan, T.; Xu, F.; Wu, J.; Zhou, E.; Wang, J.; Li, K. Ultra-Deep Oxidative Desulfurization of Model Oil Catalyzed by In Situ Carbon-Supported Vanadium Oxides Using Cumene Hydroperoxide as Oxidant. ChemistrySelect 2020, 5 , 2148-2156. [CrossRef]

157. Timko, M.T.; Schmois, E.; Patwardhan, P.; Kida, Y.; Class, C.A.; Green, W.H.; Nelson, R.K.; Reddy, C.M. Response of Different Types of Sulfur Compounds to Oxidative Desulfurization of Jet Fuel. Energy Fuels 2014, 28, 2977-2983. [CrossRef]

158. Zhang, Y.; Wang, R. Synthesis of silica@C-dots/phosphotungstates core-shell microsphere for effective oxidative-adsorptive desulfurization of dibenzothiophene with less oxidant. Appl. Catal. B 2018, 234, 247-259. [CrossRef]

159. Guimarães, I.R.; Giroto, A.S.; de Souza, W.F.; Guerreiro, M.C. Highly reactive magnetite covered with islands of carbon: Oxidation of $\mathrm{N}$ and S-containing compounds in a biphasic system. Appl. Catal. A 2013, 450, 106-113. [CrossRef]

160. Oliveira, A.A.S.; Costa, D.A.S.; Teixeira, I.F.; Moura, F.C.C. Gold nanoparticles supported on modified red mud for biphasic oxidation of sulfur compounds: A synergistic effect. Appl. Catal. B 2015, 162, 475-482. [CrossRef]

161. Rezvani, M.A.; Shaterian, M.; Shokri Aghbolagh, Z.; Babaei, R. Oxidative desulfurization of gasoline catalyzed by IMID@PMA@CS nanocomposite as a high-performance amphiphilic nanocatalyst. Environ. Progress Sustain. Energy 2018, 37, 1891-1900. [CrossRef]

162. Diaz de Tuesta, J.L.; Saviotti, M.C.; Roman, F.F.; Pantuzza, G.F.; Sartori, H.J.F.; Shinibekova, A.; Kalmakhanova, M.S.; Massalimova, B.K.; Pietrobelli, J.M.T.A.; Lenzi, G.G.; et al. Assisted hydrothermal carbonization of agroindustrial byproducts as effective step in the production of activated carbon catalysts for wet peroxide oxidation of micro-pollutants. J. Environ. Chem. Eng. 2021, 9, 105004. [CrossRef] 
163. Santos Silva, A.; Seitovna Kalmakhanova, M.; Kabykenovna Massalimova, B.; Sgorlon, J.G.; Diaz de Tuesta, J.L.; Gomes, H.T. Wet Peroxide Oxidation of Paracetamol Using Acid Activated and Fe/Co-Pillared Clay Catalysts Prepared from Natural Clays. Catalysts 2019, 9, 705. [CrossRef]

164. Souza, W.F.; Pereira, M.C.; Oliveira, L.C.A. Amphiphilic catalysts based on onion-like carbon over magnetic iron oxide for petrochemical industry use. Fuel 2012, 96, 604-607. [CrossRef]

165. Oliveira, A.A.S.; Martins, A.R.; Ferreira, R.V.; Cunha, I.T.; Serp, P.; de Mesquita, J.P.; Moura, F.C.C. N-doped carbon nanotubes grown on red mud residue: Hybrid nanocomposites for technological applications. Catal. Today 2020, 344, 247-258. [CrossRef]

166. Purceno, A.D.; Machado, B.F.; Teixeira, A.P.; Medeiros, T.V.; Benyounes, A.; Beausoleil, J.; Menezes, H.C.; Cardeal, Z.L.; Lago, R.M.; Serp, P. Magnetic amphiphilic hybrid carbon nanotubes containing N-doped and undoped sections: Powerful tensioactive nanostructures. Nanoscale 2015, 7, 294-300. [CrossRef] [PubMed]

167. Ammar, S.H.; Kareem, Y.S.; Mohammed, M.S. Catalytic-oxidative/adsorptive denitrogenation of model hydrocarbon fuels under ultrasonic field using magnetic reduced graphene oxide-based phosphomolybdic acid ( $\left.\mathrm{PMo}_{-} \mathrm{Fe}_{3} \mathrm{O}_{4} / \mathrm{rGO}\right)$. Ultrason. Sonochem. 2020, 64, 105050. [CrossRef] [PubMed]

168. Bhadra, B.N.; Song, J.Y.; Uddin, N.; Khan, N.A.; Kim, S.; Choi, C.H.; Jhung, S.H. Oxidative denitrogenation with TiO $@_{2}$ porous carbon catalyst for purification of fuel: Chemical aspects. Appl. Catal. B 2019, 240, 215-224. [CrossRef]

169. Diniz, C.V.; Nascimento, J.V.; Binatti, I.; Freitas, P.E.; Mambrini, R.V. Hybrid catalysts based on waste electrical and electronic equipment supported on bentonite for the removal of contaminants compounds in liquid phase. Catal. Today 2020, $344,75-83$. [CrossRef]

170. Martin-Martinez, M.; Ribeiro, R.S.; Machado, B.F.; Serp, P.; Morales-Torres, S.; Silva, A.M.T.; Figueiredo, J.L.; Faria, J.L.; Gomes, H.T. Role of Nitrogen Doping on the Performance of Carbon Nanotube Catalysts: A Catalytic Wet Peroxide Oxidation Application. ChemCatChem 2016, 8, 2068-2078. [CrossRef]

171. Diaz de Tuesta, J.L.; Quintanilla, A.; Casas, J.A.; Morales-Torres, S.; Faria, J.L.; Silva, A.M.T.; Gomes, H.T. The pH effect on the kinetics of 4-nitrophenol removal by CWPO with doped carbon black catalysts. Catal. Today 2020, 356, 216-225. [CrossRef]

172. Diaz de Tuesta, J.L.; Machado, B.F.; Serp, P.; Silva, A.M.T.; Faria, J.L.; Gomes, H.T. Janus amphiphilic carbon nanotubes as Pickering interfacial catalysts for the treatment of oily wastewater by selective oxidation with hydrogen peroxide. Catal. Today 2020, 356, 205-215. [CrossRef] 